\title{
INFLUÊNCIA DA IRRIGAÇÃO LOCALIZADA NA ABSORÇÃO DE ÁGUA DO PORTA-ENXERTO LIMÃO 'CRAVO', EM PLANTAS ADULTAS DE LIMA ÁCIDA 'TAHITI'.
}

\author{
CARMELLO CRISAFULLI MACHADO \\ Engenheiro Agrícola
}

Orientador: Prof. Dr. RUBENS DUARTE COELHO

Dissertação apresentada à Escola Superior de Agricultura "Luiz de Queiroz", Universidade de São Paulo, para a obtenção do título de Mestre em Agronomia, Área de Concentração: Irrigação e Drenagem.

PIRACICABA - SP

Estado de São Paulo - Brasil

JANEIRO - 2000 


\section{ERRATA}

$\mathrm{Na}$ página 41 , no segundo parágrafo, onde se lê $14,00 \mathrm{Kg} / \mathrm{m}^{3}$, leia-se 1,40 $\mathrm{gr} / \mathrm{cm}^{3}$.

Na Tabela 3 da página 42, os valores corretos de densidade são: 1,44; 1,46; 1,41 e $1,37 \mathrm{gr} / \mathrm{cm}^{3}$ respectivamente. 
Dados Internacionais de Catalogaçāo na Publicaçāo (CIP) DIVISÃO DE BIBLIOTECA E DOCUMENTAÇÃO - Campus "Luiz de Queiroz"/USP

Machado, Carmello Crisafulli

Influência da irrigação localizada na absorção de água do porta-enxerto limão 'Cravo', em plantas adultas de lima ácida 'Tahiti' / Carmello Crisafulli Machado. . Piracicaba, 2000.

92 p.

Dissertação (mestrado) - - Escola Superior de Agricultura Luiz de Queiroz, 2000. Bibliografia.

1. Absorção de água 2. Distribuição espacial 3. Fruta citrica 4. Irrigação localizada 5. Lima-taiti 6. Limão cravo 7. Porta-enxerto 8. Raiz I. Título

CDD 634.334 
À minha companheira Juliana

Aos meus pais Sidney e Vera

Dedico 


\section{AGRADECIMENTOS}

À FAPESP, pela concessão da bolsa de estudo e pelos recursos da reserva técnica.

Ao Prof. Dr. Rubens Duarte Coelho, pela amizade, pela orientação e pelo incentivo para a realização deste trabalho.

Ao Prof. Marcos Vinícius Folegatti pela amizade e pelo apoio durante o curso.

Aos professores do Setor de Irrigação e Drenagem da ESALQ/USP, pelos ensinamentos.

Ao Departamento de Engenharia Rural - ESALQ/USP, pela oportunidade concedida para a realização deste curso e pelo apoio para o desenvolvimento deste trabalho.

Aos membros da banca do exame de qualificação Prof. Dr. Edson Eiji Matsura (UNICAMP) e Prof. Dr. Francisco de Assis Alves Mourão Filho (ESALQ/USP), e da Comissão Julgadora, Prof. Dr. Nilson Augusto Villa Nova (ESALQ/USP) e Prof. Dr. Dirceu Brasil Vieira (UNICAMP), que, junto com os demais, contribuíram incisivamente na melhoria e no engrandecimento deste trabalho.

Ao Prof. Paulo C. Sentelhas e funcionários do Departamento de Física e Meteorologia da ESALQ/USP.

Aos funcionários Gilmar, Hélio. César, Lino e Davilmar, pela valiosa colaboração.

Aos companheiros do curso de pós-graduação da ESALQ/USP, e a todos os meus familiares pelo incentivo e apoio no decorrer do curso.

Finalmente, a todos aqueles que, de uma forma ou de outra, contribuíram para a concretização deste trabalho. 


\section{SUMÁRIO}

\section{PÁGINA}

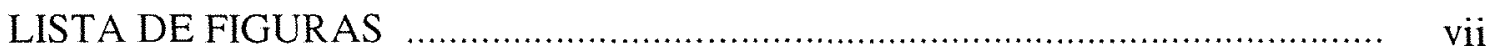

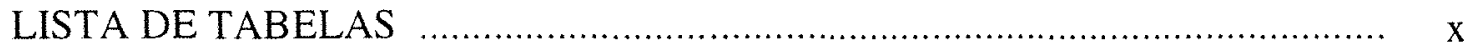

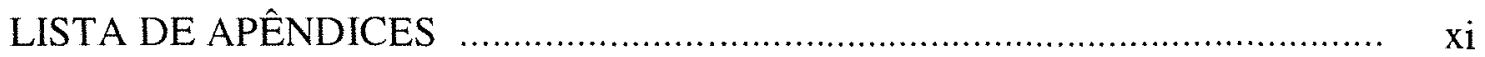

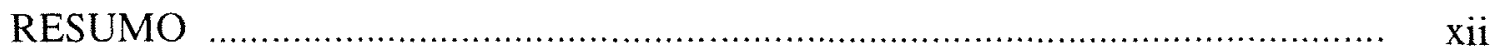

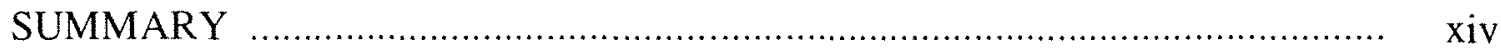

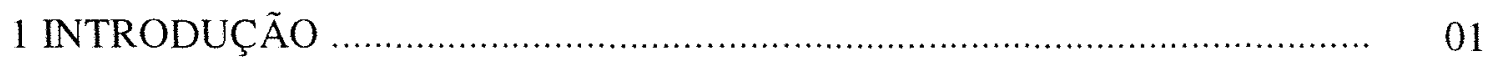

2 REVISÃO DE LITERATURA …………………...................................... 03

2.1 Considerações gerais sobre a cultura da lima ácida 'Tahiti' ........... 03

2.2 Importância do porta-enxerto ......................................................... 04

2.3 O sistema radicular das plantas cítricas ………………………..... 04

2.4 Absorção de água pelas plantas cítricas ....................................... 08

2.5 Interação água-solo-planta-atmosfera ……………………........... 09

2.6 Irrigação localizada ………….............................................. 12

2.6.1 Porcentagem de área molhada pelo sistema de irrigação . 14

2.6.2 Adaptação do sistema radicular à irrigação localizada .... 16

3 MATERIAL E MÉTODOS ....................................................................... 20

3.1 Localização e caracterização da área experimental............................. 20

3.2 Caracterização do solo ................................................................ 20

3.3 Histórico do pomar ..................................................................... 21

3.4 Escolha das plantas a utilizar nos experimentos ............................... 21

3.5 Distribuição espacial do sistema radicular do limão 'Cravo' em lima ácida 'Tahiti', por meio de imagens digitalizadas...................................... 22

3.6 Atividade espacial do porta-enxerto limão 'Cravo' em lima ácida 'Tahiti', por meio da variação do conteúdo de água no solo ...................... 26

3.7 Análise da absorção de água pela planta em diferentes áreas de umedecimento ....................................................................... 32

3.7.1 Estimativa do consumo de água pelas plantas do pomar ................ 37 


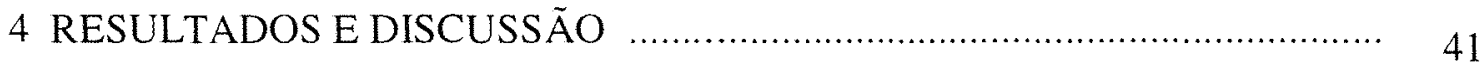

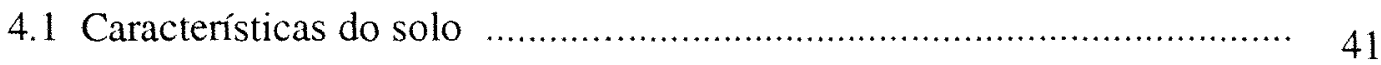

4.2 Distribuição espacial do sistema radicular do limão 'Cravo' em lima ácida 'Tahiti', por meio de imagens digitalizadas ............................... 44

4.3 Atividade espacial do sistema radicular do limão 'Cravo' em lima ácida 'Tahiti', por meio da variação do conteúdo de água no solo.

4.4 Análise da absorção de água pela planta em diferentes áreas de umedecimento

5 CONCLUSÕES 65

6 SUGESTÕES 67

REFERÊNCIAS BIBLIOGRÁFICAS 68 


\section{LISTA DE FIGURAS}

Página

1. Esquema experimental de amostragem utilizado para a quantificação da distribuição radicular através da filmagem. Disposição da tela e suas dimensões.

2. a - vista do perfil de solo a filmar; $b$ - imagem original; $c$ - imagem recortada com a escala $(25 \times 25 \mathrm{~cm}) ; \mathrm{d}$ - raízes selecionadas; e - processo de binarização da imagem e f - raízes esqueletizadas.

3. Metodologia dos anéis concêntricos utilizados na quantificação do volume de solo dos respectivos anéis. em função da distância do tronco e das profundidades analisadas para o estudo da distribuição espacial das raízes.

4. Vista superior das subáreas de estudo das respectivas baterias de tensiômetros. Anéis espaçados em $0,5 \mathrm{~m}$.

5. a- valetas onde foram instaladas lonas pretas até $60 \mathrm{~cm}$ de profundidade; b- lona preta já instalada e tensiômetros de punção; c- estrutura de madeira utilizada para sustentar a lona de polietileno e d- planta isolada.

6. Esquema de funcionamento da metodologia proposta para medir o consumo de água pela planta.

7. a- detalhe do cap superior: b- supertensiômetro de carga constante: cdetalhe da saída do reservatório e d- tubos reservatórios instalados no campo.

8. a- planta 1, 64 supertensiômetros de carga constante, $100 \%$ projeção da copa e b- planta 2.32 supertensiômetros de carga constante, $50 \%$ da projeção da copa.

9. a- posição dos tensiômetros de punção ao redor do supertensiômetro de carga constante e b- visualização gráfica do bulbo molhado. através das leituras dos tensiômetros de punção.

10. Curvas de retenção para as quatro camadas de solo em estudo. 
11. Curvas da condutividade hidráulica do solo, em função do módulo do potencial mátrico (cmc.a.), para as diferentes camadas de solo (Medeiros, 1998)

12. Isolinhas de comprimento de raiz em $\mathrm{cm}$ de raiz $/ 625 \mathrm{~cm}^{3}$ de solo, na planta 1 .

13. Isolinhas de comprimento de raiz em $\mathrm{cm}$ de raiz $/ 625 \mathrm{~cm}^{3}$ de solo, na planta 2.

14. Isolinhas do comprimento medido de raízes da planta 1, extrapolados para todo o volume de solo da planta $(\mathrm{cm}$ de raiz/volume de solo do anel correspondente).

15. Isolinhas do comprimento medido de raízes da planta 2 , extrapolados para todo o volume de solo da planta $(\mathrm{cm}$ de raiz/ volume de solo do anel correspondente).

16. Distribuição percentual do sistema radicular, em função da distância do tronco.

17. Distribuição percentual do sistema radicular, em função das camadas de solo em análise.

18. Perfil de distribuição percentual das raízes medidas no perfil de solo, valor médio das duas plantas amostradas, sem a extrapolação.

19. Perfil de distribuição percentual das raízes estimadas no volume de solo da planta, valor médio das duas plantas amostradas, com a extrapolação para todo o volume de solo.

20. Perfil de distribuição percentual da atividade radicular, em função da ETc da planta 1.

21. Perfil de distribuição percentual da atividade radicular, em função da ETc da planta 2.

22. Perfil de distribuição percentual da atividade radicular, em função do consumo de solução do solo, da planta 1 .

23. Perfil de distribuição percentual da atividade radicular. em função do consumo de solução do solo, da planta 2. 
24. Volume de água absorvido pelas plantas 1 e 2 (supertensiômetro de carga constante) e volume de água estimado pela equação de PenmanMonteith, para o primeiro período analisado.

25. Volume de água absorvido pelas plantas 1 e 2 (supertensiômetro de carga constante) e volume de água estimado pela equação de PenmanMonteith, para o segundo período analisado.

26. Análise comparativa entre a \% ideal de irrigação (vol. estimado) e os volumes percentuais absorvidos pelas plantas 1 e 2 , no $1^{\circ}$ período.

27. Análise comparativa entre a \% ideal de irrigação (vol. estimado) e os volumes percentuais absorvidos pelas plantas 1 e 2 , no $2^{\circ}$ período.

28. Análise comparativa entre a \% ideal de irrigação (vol. estimado) e os volumes percentuais absorvidos pelas plantas 1 e 2 , nos três períodos sem precipitações naturais.

29. Volume requerido na planta 1 como $100 \%$ e a porcentagem requerida pela planta 2, em relação à planta 1 .

30. Aumento percentual da atividade radicular da planta 2 , referente à planta 1. 


\section{LISTA DE TABELAS}

\section{Página}

1. Distâncias do centro de cada subárea até o tronco da árvore.

2. Valores de $n, m, \theta_{S}, \theta_{R}, \alpha$ e coeficiente de ajuste da curva de retenção de água no solo, para as diferentes profundidades.

3. Composição granulométrica e densidade aparente da área experimental.

4. Parâmetros da equação de condutividade hidráulica em função do módulo do potencial mátrico da água do solo, para as profundidades de $20,40 \mathrm{e}$ $60 \mathrm{~cm}$.

5. Resultados da evapotranspiração da cultura $(\mathrm{mm} /$ dia $)$, do consumo de solução ( $\mathrm{L} / \mathrm{dia}$ ) e coeficientes de cultura determinados para os períodos em análise.

6. Resultados do primeiro ciclo na planta 1.

7. Valores de PW e $\mathrm{P}$ em porcentagem e a área molhada pelo sistema proposto.

8. Volumes acumulados da água absorvida pelas plantas 1 e 2 e estimados pela equação de Penman-Monteith. 


\section{LISTA DE APÊNDICES}

Página

1. Vista do sistema radicular de tangor 'Murcote' na trincheira aberta paralelamente às linhas de plantio.

76

2. Descrição do perfil de solo representativo da área experimental.

78

3. Foto área do pomar de lima ácida 'Tahiti'.

80

4. Análise da atividade espacial do sistema radicular do porta-enxerto limão 'Cravo', por meio da variação do conteúdo de água no solo; resultados originais de todos os ciclos analisados. 


\title{
INFLUÊNCIA DA IRRIGAÇÃO LOCALIZADA NA ABSORÇÃO DE ÁGUA DO PORTA-ENXERTO LIMÃO 'CRAVO', EM PLANTAS ADULTAS DE LIMA ÁCIDA 'TAHITI'.
}

\author{
Autor: CARMELLO CRISAFULLI MACHADO \\ Orientador: RUBENS DUARTE COELHO
}

\section{RESUMO}

O presente trabalho foi desenvolvido na Área Experimental de Irrigação do Departamento de Engenharia Rural da ESALQ/USP (Fazenda Areão), Piracicaba-SP, em um pomar de lima ácida 'Tahiti' com 6 anos de idade. $O$ trabalho de pesquisa teve dois objetivos básicos: 1) estudar a distribuição espacial e a atividade radicular do portaenxerto limão 'Cravo' em plantas adultas de lima ácida 'Tahiti', conduzido em condição de sequeiro e 2) estudar a adaptação fisiológica à irrigação localizada do mesmo portaenxerto em plantas adultas, em função de diferentes porcentagens de área molhada no solo, visando a quantificar o aumento da atividade radicular, à medida que se reduz a porcentagem de área molhada no solo. em condições tropicais e sem o uso de fertirrigação. Desenvolveu-se o trabalho em três etapas distintas: a) mensuração da distribuição espacial do sistema radicular do porta-enxerto limão 'Cravo', através da abertura de trincheiras no campo: b) quantificação da atividade radicular. em função da 
variação de umidade no perfil de solo proveniente de irrigação ou chuva em $100 \%$ da área de projeção da copa da planta e c) quantificação da atividade radicular com irrigação localizada em $24,4 \%$ e $12,25 \%$ da área de projeção da copa através de uma nova metodologia proposta: o supertensiômetro de carga constante. Os resultados mostraram que, aproximadamente, entre 44 e 52\% do comprimento total de raízes do porta-enxerto limão 'Cravo', em condição de sequeiro, encontram-se na camada de 0 a $25 \mathrm{~cm}$ da superfície do solo. A extrapolação do comprimento total de raízes, medidas para o volume tridimensional, evidencia que a maior quantidade de radicelas se encontra do meio para o final da projeção da copa da planta, em condição de sequeiro. Isso indica que qualquer descuido por parte do citricultor, no controle das ervas daninhas, induzirá uma forte competição por água e nutrientes. com provável redução de produtividade do pomar. A atividade de absorção de água do porta-enxerto limão 'Cravo', em condição de sequeiro, na camada de $0-25 \mathrm{~cm}$ de profundidade, foi responsável por 68 a $74 \%$ do volume de solução absorvida. valor superior, em aproximadamente $24 \%$, ao do comprimento total de raízes nesta camada ( 44 a $52 \%$ ), evidenciando que as raízes mais rasas apresentam maior capacidade de absorção e de condutividade hidráulica. A adaptação do porta-enxerto limão 'Cravo', de uma planta adulta, à irrigação localizada, sem o uso de fertirrigação e nas condições climáticas do Estado de São Paulo, demorou aproximadamente 100 dias; para aumentar entre 30 e $40 \%$ a sua capacidade de absorção de água, se comparada uma planta com $24,2 \%$ e a outra com $12,2 \%$ da projeção da copa irrigada. 


\title{
INFLUENCE OF THE LOCALIZED IRRIGATION IN THE WATER UPTAKE OF THE ROOTSTOCK LEMON 'CRAVO' IN ADULT PLANTS OF LIME 'TAHITI'.
}

\author{
Author: CARMELLO CRISAFULLI MACHADO \\ Adviser: RUBENS DUARTE COELHO
}

\section{SUMMARY}

This work was carried out at the experimental area of irrigation at the Departamento de Engenharia Rural-ESALQUSP ("areão" farm); in Piracicaba - SP, in a six-years old 'Tahiti' lime orchard. The research focused on two basic objectives: 1) study the spatial distribution and the root's activity of rootstock lemon 'Cravo' in adult plants of lime 'Tahiti', non-irrigated and 2) study the physiologycal adaptation at the localized irrigation of the same rootstock under different percentages of wetted area in the soil aimming to measure the increase of the root's activity under tropical conditions without fertirrigation. The work was developed in three different stages: a) the spatial distribution measurement of the root's system at rootstock lemon 'Cravo' openning trenchs in the field: $\mathbf{b})$ root's activity measurement in function of the moisture variation in the soil profile under irrigation or rain at $100 \%$ of the canopy projection area and $\mathbf{c}$ ) root's activity measurement with localized irrigation in $24,4 \%$ and $12,25 \%$ of the canopy projection area through the new proposed methodology: supertensiometer with constant head. The results showed that approximately between 44 and $52 \%$ of the total length of the roots of the rootstock lemon 'Cravo' in a non-irrigated condition is situated in the 
layer between 0 and $25 \mathrm{~cm}$ at the soil surface. The total length extrapolated of the roots measured to the three-dimensional volume shows that the greastet quantity of roots is situated from the middle to the end of the canopy projection in a non-irrigated condition, showing that any farmer carelessness in the weeds control, it will prompt to a hard competition by water and nutrients, with probable reduction in the orchard productivity. The water uptake activity by the rootstock lemon 'Cravo' non-irrigated, in the layer between 0 to $25 \mathrm{~cm}$ depth has been the responsible by 68 to $74 \%$ in the absorbed solution volume. This value is greater in approximately $24 \%$ to the total length of the roots in this layer $(44-52 \%)$ showing that the shallow roots exhibit higer water uptake capacity and hydraulic conductivity. The rootstock lemon 'Cravo' adaptation of the adult plant at the localized irrigation, without the fertirrigation in the climatic conditions of the São Paulo state, demanded approximately 100 days to increase between 30 and $40 \%$ yours water absorption capacity comparing a plant with $24,2 \%$ and the other with $12,2 \%$ of the irrigated canopy projection. 


\section{INTRODUÇÃO}

A cultura dos citros no Brasil possui importância tanto pela área implantada, quanto pela quantidade produzida. O país ocupa posição de destaque no panorama internacional como o principal produtor de frutas cítricas e de suco concentrado, representando o Estado de São Paulo $80 \%$ da produção nacional, com 760.000 ha cultivados (FNP Consultoria e Comércio, 2000).

Para aumentar a rentabilidade de tal atividade, o citricultor irrigante poderá atuar tanto no incremento da produção física diretamente, quanto na redução dos custos operacionais da cultura, se ele tiver consciência da importância dos parâmetros de produção, tais como: densidade de plantio, controle de pragas, doenças, plantas invasoras, manejo da irrigação e adubação.

Considerando que há três mercados distintos para o fruto (suco concentrado, suco fresco e consumo in natura), o citricultor deverá definir niveis de insumos, em função do preço de venda e das exigências de qualidade em cada um desses mercados. Como os citros são frutas de produção sazonal, sua colheita deve ser programada para ocorrer nas épocas de melhor preço histórico, podendo a irrigação suprir eventuais deficiências hídricas nos períodos de floração e de crescimento dos frutos.

A irrigação sistemática de pomares cítricos é uma realidade instalada em aproximadamente 40.000 ha no Estado de São Paulo, sendo 27.000 ha em irrigação por aspersão (autopropelido e convencional) e 13.000 ha em irrigação localizada (gotejamento e microaspersão). No ano de 1999. cerca de 3000 ha de irrigação localizada por gotejamento foram implantados nas tradicionais áreas citrícolas do Estado de São Paulo, irrigando uma fração reduzida do sistema radicular de pomares adultos, visando a um menor custo de instalação do sistema (1 linha de gotejadores por linha de 
planta); essa recomendação de irrigação de citros, baseada na experiência bem-sucedida de israelenses em condição de deserto (área irrigada de 10 a $15 \%$ da projeção da copa), ainda não foi adotada em larga escala nas tradicionais áreas citrícolas irrigadas: Espanha (Valência), EUA (Flórida) e África do Sul. Não existe relato, na literatura nacional, e nem experiência prática registrada do comportamento fisiológico de um pomar adulto com a irrigação de uma fração reduzida de solo, nas condições climáticas do Estado de São Paulo, o que despertou o interesse para a realização do estudo.

O presente trabalho de pesquisa teve dois objetivos básicos: 1) estudar a distribuição espacial e a atividade radicular do porta-enxerto limão 'Cravo' em plantas adultas de lima ácida 'Tahiti' . conduzido em condição de sequeiro e 2) estudar a adaptação físiológica à irrigação localizada do mesmo porta-enxerto em plantas adultas, em função de diferentes porcentagens de área molhada no solo, visando a quantificar o aumento da atividade radicular, à medida que se reduz a porcentagem de área molhada no solo, em condições tropicais, sem o uso de fertirrigação.

Para que os objetivos traçados pudessem ser alcançados, desenvolveu-se uma metodologia de trabalho baseada em três etapas distintas: a) mensuração da distribuição espacial do sistema radicular do porta-enxerto limão 'Cravo', conduzido em condição de sequeiro, através da abertura de trincheiras no campo; b) quantificação da atividade radicular do porta-enxerto limão 'Cravo', em função da variação de umidade no perfil do solo proveniente de irrigação ou chuva em $100 \%$ da área de projeção da copa da planta e c) quantificação da atividade radicular com irrigação localizada em $24,40 \%$ e $12,25 \%$ da área de projeção da copa, através de uma nova metodologia proposta: o supertensiômetro de carga constante. 


\section{REVISÃO DE LITERATURA}

\subsection{Considerações gerais sobre a cultura da lima ácida 'Tahiti'}

Os citros são plantas nativas de uma larga região asiática que se estende do nordeste da Índia até as Filipinas e a Indonésia (Chapot, 1975). Embora originários dos trópicos úmidos, com características mesofíticas, apresentam uma ampla área de dispersão no mundo. Como cultivo comercial de expressão econômica, essa superfície é reduzida, restringindo-se às regiões subtropicais. entre $20^{\circ}$ e $40^{\circ}$ de latitude nos dois hemisférios (Ortolani et al., 1991).

Progenitores dos citros certamente estão localizados em sub-bosque de florestas de baixa latitude. Kriedemann \& Barrs (1981) relatam que, mesmo hoje, os cultivares contêm muitos atributos apropriados àquela situação como: a) o crescimento vegetativo dominante em relação ao reprodutivo. Isso se manifesta em fluxos de crescimento vegetativo, mesmo em detrimento da fixação dos frutos. Tal dominância parece ser importante para a sobrevivência da árvore nos espaços do sub-bosque; b) o desenvolvimento foliar exuberante (acima de $25 \%$ da massa fresca da árvore) e as folhas como maior reserva de carboidratos; c) a alta capacidade de transpiração, associada a uma baixa condutividade hidráulica do sistema radicular, formado por raízes suberizadas, equipadas com pêlos radiculares vestigiais. Conseqüentemente, a transpiração, sob alta demanda atmosférica. excede a capacidade de absorção de água. 


\subsection{Importância do porta-enxerto}

A propagação da cultura é feita principalmente por enxertia, existindo várias combinações de porta-enxertos e de copas na citricultura mundial. A enxertia é vantajosa, na medida que pode proporcionar às plantas uniformidade e precocidade da produção, qualidade e uniformidade dos frutos, bem como rusticidade a diversas enfermidades ou tolerância às condições adversas. No entanto, apesar da grande variedade de combinações de porta-enxertos e de copas, a citricultura brasileira está praticamente apoiada no limoeiro 'Cravo' (Pompeu Jr., 1991).

O uso de porta-enxertos pode ser vantajoso, na medida que pode conferir às plantas caracteres agronômicos interessantes. Os porta-enxertos afetam o vigor e a produtividade das plantas (Wutscher \& Bistline, 1988); a absorção de nutrientes minerais (Castle \& Kresdornm, 1975); o balanço hormonal (Stevens \& Westwood, 1984); a qualidade dos frutos (Albrigo,1977); a taxa de assimilação de gás carbônico e a transpiração (Yelenoski, 1991); a tolerância a doenças (Pompeu Jr., 1991) e à seca (Yelenoski, 1991). Observa-se que o limoeiro 'Cravo' induz as diversas copas utilizadas no Brasil a uma maior tolerância à seca (Pompeu Jr.,1991).

As diferentes combinações de porta-enxerto versus copa apresentam comportamentos diversos em relação às trocas gasosas e às relações hídricas (Castle et al., 1989). As raízes do porta-enxerto podem manter o estado de hidratação na parte aérea, em conseqüência de sua arquitetura; maior relação raíz-parte aérea; maior condutividade hidráulica ou ainda pela produção de hormônios indutores de alterações metabólicas, que garantem a absorção de água em solos mais secos (Hale \& Orcutt, 1987).

\subsection{O sistema radicular das plantas cítricas}

Geralmente o sistema radicular é formado por uma ou duas raízes pivotantes, de onde saem as raízes pioneiras. estas são firmes e fortes. Das pioneiras, saem as raízes 
fibrosas e destas, as radicelas, que, como o próprio nome diz, são flexíveis, maleávéis, como as fibrosas, ou seja, estas e as radicelas são as que absorvem água.

O sistema radicular é uma estrutura física, que dá suporte às plantas, funcionando como fundação para que o vegetal possa permanecer sobre o solo. Além disso, desempenha importantes atividades fisiológicas, tanto na síntese de fitohormônios, como na absorção da solução do solo. Tais atividades são moduladas pelos fatores que afetam a respiração, tais como a taxa de difusão do oxigênio e a temperatura do solo, que também atuam como reguladores na disponibilidade de íons, na toxidez e na presença de patógenos no solo. Por outro lado. tanto a temperatura quanto a taxa de difusão de oxigênio e a sua quantidade são influenciadas pela umidade do solo (Magalhães, 1988).

A disponibilidade de oxigênio no solo está diretamente relacionada com o acúmulo de matéria seca nas plantas, atuando sobre a emissão de radicelas; nesse sentido, é substancialmente menor a concentração de radicelas, quanto menos oxigênio estiver disponível. Se, por um lado, a umidade excessiva no solo, durante períodos de curta duração, causa redução na disponibilidade de oxigênio, isso não chega a prejudicar o sistema radicular das plantas cítricas, pois simplesmente induz a uma redução na atividade de absorção e na taxa de crescimento das raízes, à medida que a deficiência hídrica aumenta, voltando, todavia, aos níveis normais com o reumedecimeto do solo (Marsh, 1968).

A temperatura do solo também afeta diretamente o crescimento das raízes das plantas, particularmente do gênero Citros, sendo de $20^{\circ} \mathrm{C}$ a $34^{\circ} \mathrm{C}$ o intervalo adequado para o crescimento das raízes e $20^{\circ} \mathrm{C}$ a temperatura ideal (Giriton, 1927). Fora desse intervalo, o crescimento é insignificante.

As radicelas dos citros encontram-se num extrato muito superficial do solo: segundo Moreira (1988), 45,46\% da radicelas de árvores de citros adultas estão distribuídos em até $15 \mathrm{~cm}$ de profundidade: $59,36 \%$. em até $30 \mathrm{~cm}$ e $73,12 \%$, em até 60 $\mathrm{cm}$.

A água é o elemento fundamental para o desenvolvimento das raízes das plantas de citros; no entanto a extensão do seu efeito no crescimento das raízes e da 
planta, como um todo, depende de como é aplicada, da permeabilidade do solo regularmente molhado, de suas condições físicas relacionadas com o movimento da água, da temperatura do solo e da água e da interação entre aeração e disponibilidade de água para a planta, e ainda da necessidade hídrica da planta nos diferentes estádios fenológicos (March, 1968).

A manutenção das atividades fisiológicas e metabólicas dos tecidos que compõem o sistema radicular depende, também, do funcionamento harmônico das diferentes partes das plantas, principalmente das folhas, responsáveis pelos processos de produção de carboidratos, aminoácidos e outros compostos carbônicos sintetizados na fotossíntese, dos quais dependem a manutenção e o crescimento das plantas (Magalhães. 1988).

Havendo água disponível, o sistema radicular dos citros cresce continuamente, devido à absorção e à acumulação da água nos vacúolos das células, promovendo o alongamento das raízes e, assim, o crescimento, em volume, desse órgão. Simultaneamente, compostos carbônicos metabolizados são transportados das folhas e depositados como macromoléculas, constituindo os elementos estruturais dos tecidos radiculares. Além disso, os carboidratos que chegam às raízes são utilizados como substratos para a manutenção dos processos de respiração e de produção de energia metabólica. essenciais para sustentar a absorção ativa dos elementos do solo (Hilgeman. 1977).

Os maiores problemas encontrados nas técnicas de estudo da atividade e da distribuição do sistema radicular são o tempo de amostragem, a destruição do sistema exigida pelos métodos, assim como a acentuada variabilidade espacial encontrada. Tais inconvenientes têm levado ao desenvolvimento de métodos indiretos, como a variação temporal do conteúdo de água do solo, método que se baseia na hipótese de que a taxa de decréscimo de água no solo se correlaciona com a quantidade de raizes, permitindo inferir sobre a atividade do sistema radicular no perfil do solo (Bohm, 1979).

Pearson (1974) avalia que a principal vantagem desse método, além de não ser destrutivo, é que o resultado expressa diretamente a habilidade da planta em retirar água das diferentes camadas do solo. Segundo o autor, algumas condições devem ser 
assumidas: a) durante o período de medidas, não deve existir fluxo significativo de água no solo de uma camada para outra, admitindo-se perda de água unicamente por transpiração; b) no início do periodo de medidas, o perfil encontre-se igualmente molhado em profundidade.

Savage et al. (1945) encontraram diferenças na arquitetura das raízes da laranjeira 'Parson Brown', com diferentes porta-enxertos. O limão 'Rugoso' teve o mais extensivo sistema radicular; o calamodin, o mais profundo e a lima doce ou pomelo, maior abundância de raízes fibrosas finas. Ford (1952) verificou que a laranja 'Caipira' apresentou enraizamento menos profundo que o limão 'Rugoso' ou a tangerina 'Cleópatra'. Posteriormente, Ford (1964) encontrou, em plântulas de limão 'Rugoso', maior produção de raízes profundas que nas da tangerina 'Cleópatra' e o Poncirus trifoliata apresentou raízes mais esparsas que essas espécies. Castle e Krezdorn (1975) encontraram dois tipos extremos de sistema radicular, o intenso e o extensivo, com formas intermediárias entre eles. Ainda a profundidade do enraizamento foi correlacionada com o porte da planta. O limão 'Rugoso' exibiu extensivo desenvolvimento radicular, tanto lateral quanto verticalmente. Ford (1952) sugeriu que o enraizamento mais profundo do limão 'Rugoso' poderia permitir tolerância superior à seca.

Estudos com laranjeiras no Estado de São Paulo indicam que a maioria das raízes encontra-se na camada mais superficial do solo, até $60 \mathrm{~cm}$ de profundidade. Constataram, ainda, que a distribuição horizontal das raízes ocorreu num raio de $2 \mathrm{~m}$, a partir do tronco onde se encontravam de 75 a $94 \%$ das radicelas e que, em plantas com dez anos de idade. $90 \%$ das raízes se localizavam no perfil de 0 a $60 \mathrm{~cm}$ de profundidade (Montenegro, 1960).

As raízes laterais dos citros formam uma manta horizontal de raízes adventícias. com pêlos radiculares pouco vigorosos. O desenvolvimento do sistema radicular depende, em grande parte, do tipo de cavalo utilizado e das características do perfil do solo. A profundidade de enraizamento varia entre 1,2 e 2,0 m. Geralmente, 60 $\%$ das raízes encontram-se no primeiro $0.5 \mathrm{~m} ; 30 \%$, no $0.5 \mathrm{~m}$ seguinte e $10 \%$, abaixo de $1,0 \mathrm{~m}$. Quando o suprimento de água é suficiente, normalmente $100 \%$ da água são 
extraídos da primeira camada do solo, situada entre 1,2 e 1,6 m. Porém, em condições de seca, a profundidade de extração aumenta além desta distância. Durante períodos prolongados de déficit hídrico e quando o solo for profundo e bem drenado, sua água pode ser utilizada numa profundidade de 2 a 3 m (Doorenbos e Kassam, 1979).

Rodriguez et al. (1978) constataram que o sistema radicular de três portaenxertos de citros se localiza na camada de 0 a $10 \mathrm{~cm}$ na proporção: 41,33 e $28 \%$, respectivamente, para o Trifoliata, o limão Cravo e a laranja Caipira. Observaram, ainda, que, para a profundidade de $50 \mathrm{~cm}$, a proporção era a seguinte: $91 \%, 81 \%$ e $79 \%$.

Apesar da importância do tema. tem sido pouco estudada a influência de práticas de manejo da irrigação no desenvolvimento do sistema radicular das plantas cítricas. De acordo com Castle et al. (1989), o conhecimento sobre as taxas de crescimento, e sobre a extensão e a distribuição do sistema radicular é essencial à produção de citros, pela sua importância na nutrição e na absorção de água e porque tal sistema é diretamente afetado por tratos culturais, por adubação e por irrigação. Segundo esses autores, produzir bem significa manejar bem o sistema radicular.

\subsection{Absorção de água pelas plantas cítricas}

Segundo Reichardt (1990), são inúmeros os fatores que afetam a absorção de água pelas plantas, sendo a importância de cada um relativa, dependendo de cada caso em particular. Tais fatores, sem obedecer a uma ordem preferencial, são: a) referentes à planta: extensão e profundidade do sistema radicular, superfície e permeabilidade radicular, idade das raízes e atividade metabólica da planta; b) referentes à atmosfera: umidade relativa do ar, disponibilidade de radiação solar, vento e temperatura do ar; c) referentes ao solo: umidade, capacidade de água disponível, condutividade hidráulica, temperatura, aeração e salinidade da solução do solo.

Embora a arquitetura e a condutividade hidráulica das raizes possam melhorar a capacidade de absorção de água e manter a copa mais hidratada, também podem levar ao secamento mais rápido do solo. Laborem et al. (1991) observaram, em cultivo irrigado de laranjeira 'Valência'. que o porta-enxerto limão 'Volkameriano', devido à 
sua grande capacidade de absorver água, promoveu o secamento mais rápido do solo, exigindo uma frequêencia maior de irrigação que os porta-enxertos citrange 'Carrizo' e tangerina 'Cleópatra'.

A melhor forma de se medir a absorção de água pelas plantas é através da transpiração. Em culturas agrícolas, torna-se, porém, difícil a medição da transpiração em separado, porque o solo também perde água por evaporação através de sua superfície. A absorção de água pelas plantas pode também ser estimada através da variação de armazenamento de água no solo, para um período sem chuva, no qual o movimento descendente de água no perfil é desprezível. Se a cultura cobrir totalmente o solo, a evaporação deste pode ser desprezada e a perda total de água é igual à absorção radicular das plantas (Reichardt. 1990).

\subsection{Interação água-solo-planta-atmosfera}

A condutividade hidráulica do sistema radicular constitui um dos fatores determinantes do movimento da água no sistema planta-atmosfera. Uma maior condutividade pode permitir melhor hidratação das folhas e maior abertura dos estômatos, facilitando as trocas gasosas e mantendo as folhas mais hidratadas (Sinclair \& Allen Jr.. 1982).

O conceito de disponibilidade de água no solo, em algumas circunstâncias, baseia-se na transmissividade hidráulica do meio poroso em direção às raízes. Quando a demanda de água da planta e da atmosfera é suprida pela intensidade de fluxo de água do solo para a raiz, diz-se que a água está disponível para a planta. No entanto a planta entra em condição de déficit hídrico, quando o fluxo deixa de suprir essa demanda. $O$ efeito do déficit hídrico no vegetal é um processo que envolve os efeitos hidráulicos dentro de cada um dos seus órgãos, particularmente na condutância das folhas. Combinam-se eles com alterações químicas, que intensificam a síntese do etileno, o qual irá determinar a queda de folhas. Havendo a abscisão, ocorrerá uma redução da superfície foliar, minorando-se, assim, a perda de água pelo vegetal, por 
evapotranspiração, e causando um aumento do potencial hídrico das folhas remanescentes (Castro, 1994).

A grande variabilidade temporal das chuvas, principalmente no outono e no inverno, determina a desuniformidade de ocorrência de eventos fenológicos que afetam a produção e a qualidade dos frutos das plantas cítricas (Giorgi, 1991).

Estas não respondem ao fotoperíodo para a floração, sendo o regime termopluviométrico responsável pela ocorrência de floradas, o que leva, muitas vezes, a ocorrer mais de uma florada por ano. A interação dos fatores temperatura e disponibilidade hídrica para a planta desencadeia reações metabólicas relacionadas com balanço entre carboidratos e nitrogênio, que são os substratos para a síntese metabólica, juntamente com os hormônios vegetais (Giorgi et al., 1991).

Os efeitos tanto de temperaturas baixas, como de seca, podem desencadear o processo de indução floral, que culmina com a floração. No entanto, na ausência de deficiência hídrica, é a temperatura que atua predominantemente na sensibilização da planta (Tubelis e Sabile, 1991).

Após o término da floração, inicia-se o crescimento dos frutos. Nesse período, a planta apresenta alta taxa respiratória (meses de agosto a janeiro), e tanto na fase de início de frutificação, como na fase final de formação dos frutos, a queda desses (abortamento de chumbinhos), decorrente de choques térmicos e principalmente de déficit hídrico no solo, pode ser determinante para a produção (Tubelis e Salibe, 1991).

Uma das maneiras de se avaliar como as plantas se adaptam às condições adversas é verificar a eficiência de assimilação de $\mathrm{CO}_{2}$, para a síntese de carboidratos necessários ao crescimento e ao desenvolvimento. Para o $\mathrm{CO}_{2}$ atmosférico atingir os cloroplastos, nas células do mesófilo foliar, e ser reduzido a carboidrato, é necessário que penetre na folha pelos estômatos e se difunda entre os espaços inter e intracelulares. A abertura estomática, entretanto, permite que ocorra perda de água, devido ao gradiente de potencial hídrico estabelecido entre a superfície interna hidratada e a atmosfera. Condições naturais propícias à fixação de carbono favorecem a abertura dos estômatos, enquanto condições propícias à perda de água favorecem o seu fechamento. Ou seja, se, por um lado, a queda da condutância estomática diminui a perda de água. no período de 
maior demanda hídrica pela atmosfera, por outro, há queda da assimilação de $\mathrm{CO}_{2}$. $\mathrm{O}$ movimento estomático é o meio mais rápido de que a planta dispõe para ajustar-se às variações ambientais a que as folhas são submetidas. A regulagem da abertura estomática ocorre por mecanismos complexos, que parecem agir no sentido de minimizar as perdas de água e de maximizar a assimilação de gás carbônico, de modo a otimizar as trocas gasosas (Cowan, 1982). Esses processos são determinados geneticamente. Parte das respostas ao estresse ocorre no nível foliar, em resposta ao estímulo gerado nas próprias folhas, ou em outra parte da planta.

É comum a ocorrência da depressão da taxa de assimilação de $\mathrm{CO}_{2}$ entre as 12:00 e as 14:00 devido a um fechamento parcial do estômato (Dowton et al. 1988), o que causa redução simultânea da perda de água. Em geral, a queda da assimilação está associada ao aumento do déficit de pressão de vapor d'água no ar, que frequientemente ocorre com o aumento da temperatura nas horas de maior intensidade de radiação solar (Khairi \& Hall, 1976). Para Kaufmann (1977), a condutância estomática diminui durante o dia, mas não proporcionalmente ao déficit de pressão de vapor; foi de $0,2 \mathrm{~cm} . \mathrm{s}^{-1} \mathrm{o}$ valor máximo de condutância estomática encontrado na laranjeira 'Valência.'

Se, por um lado, a queda da condutância diminui a perda de água, no período de maior demanda hídrica pela atmosfera, economizando água, por outro, há queda da assimilação de gás carbônico. Isto significa que o potencial fotossintético não está sendo realizado. A manutenção da taxa de assimilação de gás carbônico, nos horários de maior quantidade de energia disponível, seria vantajosa, uma vez que os fotoassimilados constituem a única fonte de substrato orgânico para o crescimento e a produção em plantas. Quando se objetiva a alta produtividade, talvez o ideal fosse que a planta economizasse água somente quando as condições hídricas do solo fossem inadequadas, procurando manter, em condições hídricas favoráveis, altas taxas de transpiração e de assimilação de $\mathrm{CO}_{2}$ (Machado \& Lagôa. 1994).

A depressão na assimilação de $\mathrm{CO}_{2}$ pode também relacionar-se à temperatura. Temperaturas ideais para a atividade fotossintética do citros ocorrem entre 25 e $31{ }^{\circ} \mathrm{C}$. Nos limites de 38 a $40^{\circ} \mathrm{C}$, ou abaixo de $12{ }^{\circ} \mathrm{C}$, a atividade fotossintética é praticamente nula. Temperaturas altas aumentam a taxa de respiração, diminuem a taxa de 
fotossíntese e podem reduzir a atividade de enzimas e até desnaturá-las (Hale \& Orcutt, 1987).

\subsection{Irrigação localizada}

As áreas de produção de citros no Estado de São Paulo estendem-se do sudeste úmido até o noroeste seco. Geralmente, a estação seca coincide com os meses mais frios do ano, o que constitui um contraste com o clima das regiões mediterrâneas de produção de citros, onde a estação seca ocorre nos meses quentes de verão e as chuvas, no inverno. Essas diferenças climáticas refletem-se no desenvolvimento do sistema radicular: sob as condições do Mediterrâneo, o sistema radicular desenvolve-se de acordo com o bulbo molhado pelo emissor do sistema de irrigação, nos meses quentes e secos do verão, enquanto, sob as condições do Estado de São Paulo, as precipitações ocorridas nos meses quentes é que podem estar condicionando o desenvolvimento do sistema radicular. A situação é diferente nos pomares supridos pelas chuvas e que necessitam somente de irrigações suplementares, relativamente pequenas, e apenas nos períodos críticos (de 2 a 3 meses). No Estado de São Paulo, caso o sistema radicular dos citros venha a desenvolver-se basicamente em função das precipitações naturais, a dúvida que surge é se o sistema de irrigação muito localizado será capaz de suprir as quantidades de água e nutrientes requeridas para o florescimento e para a frutificação da planta (Spieler $\left.{ }^{1}\right)$

No Estado de São Paulo, a cultura do limão 'Tahiti' tem adaptabilidade, praticamente em todas as regiões, com exceção daquelas onde a carência térmica limita seu desenvolvimento, como nas serras. O período de maior produção concentra-se entre janeiro e julho, quando os preços oscilam entre $\mathrm{R} \$ 1.50$ e $\mathrm{R} \$ 2,00$ por caixa de $27,7 \mathrm{~kg}$. A partir de agosto, os preços por caixa começam a subir, devido à entressafra, chegando ao preço máximo de aproximadamente $\mathrm{R} \$ 20,00 \mathrm{em}$ novembro, a partir de quando voltam a cair (Boteon, 1997). Devido a essa curva estacional de preços bem definida, a

\footnotetext{
'SPIELER G. ( Dan Sprinklers, Irrigation Equipment) Comunicação pessoal (1999)
} 
obtenção da maturação dos frutos na entressafra torna-se altamente vantajosa.

A indução floral na cultura do limão 'Tahiti' é pratica comum entre os produtores mais tecnificados, seja através da irrigação após um período de estresse hídrico, seja por meio da aplicação de hormônios vegetais associados à adubação nitrogenada, ou ainda, da derriça. Essa prática visa à obtenção de florada uniforme e ao controle do período de colheita. Sentelhas et al. (1997), utilizando um método agrometeorológico de estimativa da época mais adequada para a indução floral do limão 'Tahiti' no Estado de São Paulo, identificaram diversos períodos médios de tempo de antecedência com que a indução floral deve ser feita no limão 'Tahiti', para que a colheita coincida com a entressafra. A duração média entre o florescimento e a maturação variou de 127 a 327 dias, para as colheitas em 15 de outubro, e de 107 a 294 dias, para as colheitas em 15 de novembro, o que difere da recomendação de uma antecedência fixa de 120 dias (Marcondes, 1991).

Tubelis (1995) recomenda que os pomares sejam irrigados, principalmente nos meses de seca, com o propósito de concentrar a florada e, conseqüentemente, a produção. Salienta que, quanto mais uniforme forem as floradas, menor será o custo de manejo e maior será a produção de frutos viáveis, além de se uniformizarem as condições dos frutos na colheita.

Para uma planta adulta, os processos que causam a maior demanda por nutrientes e água são o florescimento e a frutificação, fazendo com que haja um aumento das atividades metabólicas das folhas. responsáveis pela produção dos compostos orgânicos. Principalmente nessa fase, a preservação do sistema radicular em pleno funcionamento é importante para se conseguir tanto a geração, como a fixação de um maior número de frutos (Giorgi et al., 1991).

Dentre os sistemas de irrigação utilizados nos pomares cítricos, destaca-se a utilização da irrigação localizada. Arruda et al. (1994) comentam que, na fruticultura. em virtude do maior espaçamento entre as plantas. há possibilidade de maior economia de água com a irrigação localizada.

Pomares irrigados por gotejamento ou por microaspersão, em geral, são menos sujeitos a problemas de Phytophora que aqueles irrigados por aspersão convencional. 
Nos sistemas de irrigação localizada, o solo permanece por mais tempo a uma umidade alta, dificultando a frutificação do fungo. Também um menor volume de solo fica saturado e, com isso, um menor volume de propágulos passa a ser produzido devido à irrigação (Feichtenberger, 1990).

Os benefícios da irrigação para a citricultura são indiscutíveis, porém, em regiões cujas condições climáticas não são bem definidas, e onde ocorrem variações anuais, principalmente no que se refere à distribuição temporal e à altura total precipitada, os rendimentos econômicos da citricultura irrigada comparada à de sequeiro, devem ser quantificados a médio e longo prazos ( 5 a 10 anos).

\subsubsection{Porcentagem de área molhada pelo sistema de irrigação}

O efeito da irrigação localizada é o umedecimento de apenas uma parte do solo. O fato remete a uma questão fundamental: qual porcentagem do volume de solo deve ser irrigada, para que a planta consiga suprir suas necessidades hídricas, ou até que ponto podemos reduzir o volume de solo úmido, comparado com os métodos convencionais de irrigação (Pizarro, 1996)?

Um dos fatores mais importantes a considerar, no cálculo de uma instalação, é a proporção de superfície, ou de volume de solo, que deve ser umedecida, com respeito à superfície total, ou ao volume de solo que pode estar ocupado pelas raízes (projeção da copa), normalmente designado por $\mathrm{P}$ e expresso em porcentagem. Não se tem estabelecido um valor "mínimo absoluto" para P. Black (1971), em ensaio de curto prazo, observou que as maçãs jovens continuam crescendo, normalmente, mesmo que só se aplique água à quarta parte do sistema radicular $(\mathrm{P}=25 \%)$. Cerca de 50 por cento $(\mathrm{P}=50 \%)$ parecem ser suficientes. Uma média razoável para o cálculo de um projeto é umedecer pelo menos um terço $(\mathrm{P}=33 \%)$ do conjunto da zona radicular potencial, no caso de um pomar onde as plantas estejam espaçadas. Se as plantas estão juntas, deve-se umedecer todo o volume do solo para assegurar, a cada planta. água em quantidade suficiente. Em áreas com chuvas intermitentes intensas durante o ciclo e onde a irrigação 
tem caráter suplementar, $\mathrm{P}=20 \%$ parece ser uma base razoável de cálculo (Vermeiren et al., 1980).

Segundo Bernardo (1995), a fração de área molhada (PW) depende do espaçamento entre os gotejadores, ou entre os pontos de descarga nos gotejadores de múltipla saída; da vazão dos gotejadores; do tempo ou da lâmina aplicada por irrigação e do tipo de solo. Na determinação do valor de $\mathrm{PW}$, há dois casos a considerar: o primeiro, quando se irriga uma faixa contínua do solo utilizado nos cultivos em fileira, e com menores espaçamentos entre as plantas ao longo das fileiras; o outro, quando se irriga por árvore, ou seja, não se formará uma faixa molhada contínua, mas sim áreas molhadas. distintas por árvore.

A porcentagem de área molhada ( $\mathrm{PW}$ ) é calculada em função do espaçamento de plantio do pomar e da área molhada. já a relação entre à área de projeção da copa da planta e a área molhada $(\mathrm{P})$ é calculada da seguinte forma:

$$
\begin{aligned}
& \mathrm{Pw}=\frac{\text { Área molhada por planta }}{\text { Área total (espaçamento de plantio) }} \\
& \mathrm{P}=\frac{\text { Área molhada por planta }}{\text { Área de projeção da copa }}
\end{aligned}
$$

A escolha do valor de $\mathrm{P}$ tem muita importância, pois altos valores de $\mathrm{P}$ aumentam a segurança do sistema, principalmente nos períodos de altas taxas de evapotranspiração. É que um maior volume de solo explorado pela raízes permite maior absorção de água e contém maior volume de água disponível no solo, aumentando sua disponibilidade, caso aconteça algum problema no equipamento de irrigação. Com relação aos custos do projeto, quanto maior o valor de $\mathrm{P}$, maior o custo de instalação (maior número de emissores por planta). Já quanto maior o intervalo entre irrigações, maior o risco, para valores de $\mathrm{P}$ próximos ao mínimo (Pizarro, 1996). 


\subsubsection{Adaptação do sistema radicular à irrigação localizada}

A irrigação de pomares, com microaspersor ou gotejador, é uma técnica em expansão em todo mundo. Essa prática levou a vários experimentos, com diferentes frações de áreas molhadas, notando-se mudanças no desempenho das raizes das árvores monitoradas. A aplicação freqüente de quantidades de água para uma área de menor superfície molhada correspondeu a uma melhora na eficiência de absorção, com pequeno impacto no crescimento de plantas cítricas (Bielorai,1982; Moreshet et al., 1983). Tais estudos revelam não ser necessário o suprimento de água em todo o sistema radicular da planta, para que ocorra um aumento da produtividade, porque as plantas têm a capacidade de se adaptar a mudanças drásticas na fração de área molhada pela irrigação (Poni et al., 1992). Quando a zona radicular é inteiramente provida de água, as raízes têm o potencial de transferi-la a taxas muito maiores que as normalmente obtidas.

Moreshet et al. (1983) constataram que as raízes das árvores parcialmente irrigadas contribuíram com aproximadamente $90 \%$ para a transpiração total da temporada, considerando que os $10 \%$ restantes vieram das raízes que residem na terra mais seca.

Tan \& Buttery (1982) verificaram que as exigências do pêssego por água poderiam ser satisfeitas irrigando-se somente a metade da zona radicular. Poni et al. (1992) obtiveram resultados semelhantes, com experiências ao dividir ao meio as raízes de maçã, de uva, de pêssego e de pêra. Perceberam uma retenção de água na metade do sistema radicular, onde o efeito foi pequeno em relação ao total de água utilizado pela planta. Assim. Poni et al. (1992) verificaram um efeito compensatório na área molhada do sistema radicular, concluindo que a irrigação de uma parte desse sistema é melhor para a absorção de água, como resposta aos diferentes níveis de água disponível na zona radicular da planta.

Green e Clothier (1995) observaram maior absorção de água na porção do sistema radicular de kiwi molhada pela irrigação localizada, concluindo que o fato se relaciona com maiores distribuição. comprimento e densidade radicular. Observaram-se, ainda, uma atividade irregular perto da superfície do solo. camada onde ocorreu maior 
absorção de água. Como as plantas de kiwi são capazes de mudar rapidamente o modelo de absorção, nas regiões secas, quando irrigadas, passam a extrair água já com facilidade. bastando tê-la disponível para que o processo de absorção funcione bem.

Em cinco anos estudando a produção da laranja 'Valência' e sua resposta à quantidade de água aplicada pelo método de irrigação por gotejamento, Koo e Smajstrla (1984) basearam suas irrigações em 100\%, 50\% e 25\% do potencial de evapotranspiração, calculado a partir do resultado da evaporação. Os pomares de citros mais antigos não foram influenciados pela quantidade de água aplicada, ou seja, todos os tratamentos receberam água para evitar o "stress hídrico". A produtividade resultante dos diferentes métodos de irrigação estudados foi relatado: no sistema do tipo microaspersão, com cobertura de $28 \%$ a $51 \%$ da área debaixo da copa da árvore, observou-se uma majoração, no rendimento, de $65 \%$, quando comparado à testemunha não irrigada; já o sistema de irrigação por gotejamento, com cobertura de 5 a $10 \%$ da área debaixo da copa da árvore, aumentou o rendimento em $44 \%$.

De acordo com Green et al. (1997), o fluxo de seiva na raiz de macieira irrigada aumenta em $50 \%$ após a irrigação por gotejamento, com um bulbo molhado de aproximadamente $0,6 \mathrm{~m}$ de diâmetro e $0,25 \mathrm{~m}$ de profundidade. O fluxo de seiva nas raízes irrigadas foi-se elevando por um período de dez dias, até que a maioria da água disponível tivesse sido consumida. Tais resultados demonstram que as raízes das macieiras têm a capacidade de transferir água em grande quantidade de pequena área molhada. se comparada com o padrão que normalmente ocorre quando toda zona radicular é suprida de água. E ainda são capazes de substituir rapidamente o modelo de absorção de água e de começar a absorvê-la das regiões onde a mesma esteja mais disponível.

Segundo Goell (1992), algumas indagações surgiram com o aparecimento da necessidade de se determinar o volume de solo a ser irrigado. Nesse sentido, conclui que um volume molhado de 50 a $70 \%$ do solo é tão eficiente para o suprimento de água, quanto os $100 \%$ exigidos no contexto teórico da irrigação até então utilizada. Descobriu que o sistema radicular das plantas cítricas adapta-se às condições de irrigação parcial do solo, e que o crescimento extra de radicelas compensa esse menor volume molhado. 
Segundo o autor, a fase de adaptação é mais difícil em solos arenosos e para plantas cítricas adultas; neles, porém, a manutenção constante de um volume com nível adequado de umidade, por meio de irrigações de alta frequência, favorece o ajuste das raízes à nova condição.

O volume de solo molhado na irrigação por gotejamento é muito menor, quando comparado com outros métodos de irrigação. Entretanto o desenvolvimento de um sistema radicular bastante ativo compensa a redução do volume de solo explorado, através do uso mais eficiente da água e dos nutrientes no volume molhado (Olitta, 1984).

Em regiões áridas e semi-áridas, quando a irrigação tem papel decisivo no fornecimento de água à cultura. o desenvolvimento do sistema radicular pode ser manipulado em função da irrigação. Nessas condições, o sistema radicular das plantas vai se desenvolver e ficar limitado à parte úmida do solo, quando irrigado. Por outro lado, em condições de irrigação suplementar, as chuvas interferem no desenvolvimento do sistema radicular, sendo mais difícil a determinação precisa da distribuição.

Sob o aspecto da irrigação suplementar, Vieira (1988) relatou que ela deve ser iniciada quando as plantas cítricas ainda estão jovens, até no máximo três anos de idade. Isso porque a irrigação, durante a fase em que a planta é jovem, tem grande influência no crescimento vegetativo, levando ao desenvolvimento de plantas adultas com maior vigor e maior capacidade produtiva. A implantação de irrigação em plantas adultas pode ser realizada, porém o sistema radicular da cultura terá que se adaptar à nova situação para beneficiar-se da irrigação, o que pode levar cerca de três anos.

Em pomares de tangor 'Murcote', localizados no Estado de Sergipe, Lourenço et al. (1999) constatou a perfeita adaptação do sistema radicular à irrigação localizada implantada em pomares jovens. O Apêndice 1, mostra o sistema radicular de tangor 'Murcote' já adaptado à irrigação por gotejamento. As fotos indicam que o perfil de solo foi aberto paralelamente às mangueiras de irrigação por gotejamento do pomar. No Estado de Sergipe as precipitações são distribuídas em oito meses do ano e nos outros quatro os pomares são irrigados, muito parecidas com as precipitações no Estado de São Paulo, porém defasadas em seis meses no tempo. 
A irrigação suplementar realizada no Estado de São Paulo tem a duração aproximada de 4 meses. Durante 8 meses do ano, o sistema radicular tem água disponível em $100 \%$ da área. devido à ocorrência de precipitações; dessa forma, os sistemas de irrigação que utilizam uma pequena fração de área molhada poderão não suprir adequadamente a necessidade hídrica da cultura, no período de irrigação.

A maioria das experiências relatadas na literatura, com as diferentes culturas, indicam que, irrigando-se uma área de 50\% da projeção da copa, a planta irá se adaptar rapidamente a esse novo padrão de absorção de água. Do ponto de vista econômico, levando em conta a redução dos custos com as tubulações de polietileno e o número de emissores por planta, o ideal seria projetar sistemas de irrigação localizada irrigando entre 10 e 15\% da projeção da copa, nos pomares cítricos do Estado de São Paulo. Outro detalhe a considerar é que, normalmente, os pomares em que se faz a opção pela irrigação apresentam um índice de cobertura do solo de 30\%, na condição de sequeiro, o que deverá passar a $60 \%$ com a irrigação, diminuindo a área molhada (P) para 5 a 7,5\% da projeção da copa. Na literatura disponível, o relato de pesquisas de irrigação localizada na faixa de 5 a $15 \%$ de P é escassa e, especificamente para citros, inexistente. 


\section{MATERIAL E MÉTODOS}

\subsection{Localização e características da área experimental.}

$O$ experimento foi conduzido na área experimental de irrigação do Departamento de Engenharia Rural, na fazenda Areão, pertencente à Escola Superior de Agricultura "Luiz de Queiroz" - USP, no município de Piracicaba, SP, situado nas coordenadas geográficas de $22^{\circ} 42^{\circ}$ de latitude sul e $47^{\circ} 38^{\circ}$ de longitude oeste e altitude de $540 \mathrm{~m}$. O clima da região, na classificação climática de Köppen, é do tipo Cwa, isto é, subtropical úmido, com três meses mais secos (junho, julho e agosto), chuvas de verão, seca de inverno, temperatura média do mês mais quente superior a $22^{\circ} \mathrm{C}$ e a do mês mais frio inferior a $18^{\circ} \mathrm{C}$ (Bezerra,1995).

\subsection{Caracterização do solo.}

O solo da área é classificado como Terra Roxa Estruturada. No Apêndice 2, é apresentada a descrição de um perfil representativo da área.

A densidade global do solo foi determinada mediante a amostragem volumétrica para as quatro camadas de solo em estudo. Para o cálculo da capacidade de retenção, foram determinadas, com o auxílio do extrator de placas de Richards, as curvas características da água no solo para as quatro camadas. Amostras deformadas também foram coletadas nas quatro profundidades em estudo, para determinar-se a composição granulométrica do solo. 


\subsection{Histórico do pomar.}

O pomar de sequeiro foi instalado em 1993, no espaçamento de $8 \mathrm{~m} \times 7 \mathrm{~m}$, no final do ano de 1995, instalou-se um sistema de irrigação localizada, utilizando microaspersores DAN 2001, com vazão de $22 \mathrm{~L}$ h e bailarina preta. O sistema de irrigação era operado esporadicamente, com finalidades didáticas, não se conduzindo a irrigação de maneira contínua e nem com fertirrigação, caracterizando o desenvolvimento do pomar em condição de sequeiro. O manejo de solo, realizado no pomar, segue esta lógica: nas entrelinhas do pomar, o solo é mantido com vegetação natural, com controle mecânico quando necessário, e, nas saias das plantas, o controle da vegetação se faz com herbicidas ou por capina manual. As adubações do pomar são realizadas no período de chuva e parceladas em três aplicacões, totalizando $250 \mathrm{~g}$ de uréia e $170 \mathrm{~g}$ de $\mathrm{KCl}$ (cloreto de potássio) por planta do pomar. As aplicações se fazem manualmente, distribuindo-se os adubos na área de projeção da copa da planta.

\subsection{Escolha das plantas a serem utilizadas nos experimentos.}

A escolha das plantas baseou-se no trabalho de Coelho Filho (1998), que estudou a variabilidade e a dependência espacial dos componentes granulométricos do solo, a densidade do solo, o potencial mátrico do solo e a retenção de água; além disso mapeou e identificou as zonas com baixa variabilidade, por meio do processo de interpolação por "krigagem", visando a definir um manejo racional da irrigação, de modo a associar as propriedades físicas do solo com o consumo hídrico das plantas do pomar de lima ácida 'Tahiti'. A subdivisão que melhor expressou o comportamento de consumo no pomar foi a de 4 regiões diferenciadas. com Kc variando de 0,56 a 1,2. Com isso, escolheram-se duas plantas, com diâmetro de copa de $5,6 \mathrm{~m}$., que pertenciam à mesma zona com baixa variabilidade de consumo: para a realização das etapas b e c. Outras duas plantas com o mesmo diâmetro foram escolhidas para a realização da etapa a (Anexo 3). 


\subsection{Distribuição espacial do sistema radicular do limão 'Cravo' em lima ácida 'Tahiti', por meio de imagens digitalizadas.}

Para o estudo da distribuição do sistema radicular, utilizaram-se duas plantas selecionadas para a abertura das trincheiras: uma retroescavadeira abriu-as até a profundidade de 1,80 metro, a partir da superfície do solo, e 3,5 metros de comprimento a partir do tronco da planta, no sentido da linha de plantio da cultura, distante do tronco 0,5 metro. Após a abertura das trincheiras, foram realizados os seguintes passos: a) exposição das raízes, por meio de lavagem do solo com água. de apenas $1 \mathrm{~cm}$ de profundidade, de tal forma que a parede da trincheira permanecesse em nível com a vertical; como a imagem a ser adquirida representa um volume de solo conhecido $(25 \mathrm{~cm}$ altura $\times 25 \mathrm{~cm}$ comprimento $\times 1 \mathrm{~cm}$ de profundidade), foi possível a aquisição da imagem com a quantidade de raízes presente no volume de solo desejado; b) pintura localizada das raízes com tinta spray de coloração branca, visando a aumentar o contraste em relação ao solo para facilitar a aquisição das imagens (com o auxílio de uma espátula, retirou-se o excedente de tinta do perfil do solo); c) o perfil de solo foi dividido com barbantes pintados de azul anil, para evitar reflexo na hora da filmagem, em quadrados de 25 por 25 centímetros $\left(625 \mathrm{~cm}^{2}\right)$, para a aquisição das imagens, através de um quadro de $3,5 \mathrm{~m}$ de comprimento e $1,5 \mathrm{~m}$ de altura, como mostra a Figura 1. 


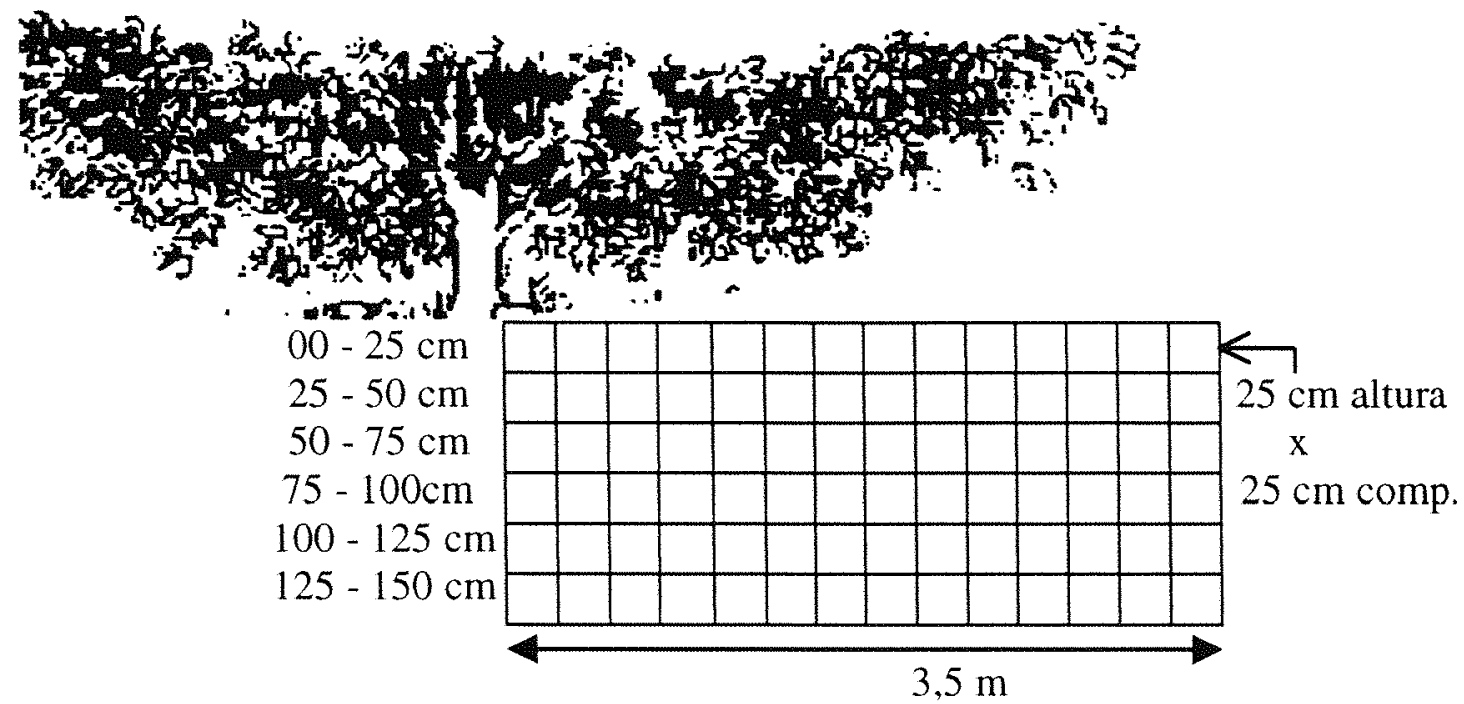

Figura 1. Esquema experimental de amostragem utilizado para a quantificação da distribuição radicular através da filmagem. Disposição da tela e suas dimensões.

Para a realização das filmagens, os perfis de solo foram umedecidos com uma piceta para realçar melhor as raízes pintadas. Foi escolhido o período da manhã, para evitar a incidência direta do sol no perfil. As imagens foram feitas com filmadora de vídeo comum, à distância de um metro do perfil. Digitalizaram-se as imagens obtidas para cada quadrícula, utilizando-se uma placa digitalizadora, com resolução espacial igual a 512 x 512 pixels. Em seguida, tais imagens foram tratadas no programa COREL DRAW, regulando-se contraste e brilho e convertendo-as para 256 cores ( 8 bits).

Para o processamento das imagens, foi utilizado o "software" SIARCS (Sistema Integrado para Análise de Raízes e Cobertura do Solo), desenvolvido pela EMBRAPA/ CNPDIA - São Carlos/SP (Crestana et al., 1994), que permite avaliar a distribuição do sistema radicular da cultura quanto à porcentagem de área e ao comprimento de raízes. Após digitalizadas e tratadas, as imagens foram abertas no SIARCS, para a devida seleção das áreas internas dos quadrados demarcados pelo barbante e, ainda. para a criação da escala 25 por 25 centímetros na imagem digitalizada. Em seguida. as raízes foram selecionadas com o auxílio dos filtros de cores TRESHOLDING, presentes no software. O passo seguinte foi a "binarização", que consiste na transformação dos 256 
tons em apenas dois (preto e branco), permitindo, assim. a identificação dos pixels que representam as raízes (em preto) e o restante da imagem (em branco). A quantificação da imagem foi feita por meio de um levantamento de seu histograma, a frequência das regiões claras e escuras em uma imagem. Assim, o cálculo da densidade de raízes foi efetuado dividindo-se o número de "pixels" correspondente às raízes (em preto) pelo total de "pixels" da imagem. Para os cálculos do comprimento das raízes, as imagens passam pelo processo de esqueletização que. para permitir que o comprimento das raízes seja medido, consiste em afiná-las à espessura de uma linha, conforme Figura 2. O resultado final foi expresso em comprimento de raízes, presentes em $625 \mathrm{~cm}^{3}$ de solo.

A análise da distribuição espacial do sistema radicular da lima ácida 'Tahiti' utilizou um esquema de anéis concêntricos, para calcular as áreas dos respectivos anéis de solo e o volume de solo para as diferentes distâncias e profundidades analisadas. Como as imagens digitalizadas também representam um volume de solo $(25 \mathrm{~cm} \times 25 \mathrm{~cm}$ $\mathrm{x} 1 \mathrm{~cm}=625 \mathrm{~cm}^{3}$ ), pode-se estimar a distribuição espacial do sistema radicular. $\mathrm{O}$ esquema dos anéis de solo, adotado nos cálculos, é mostrado na Figura 3. 


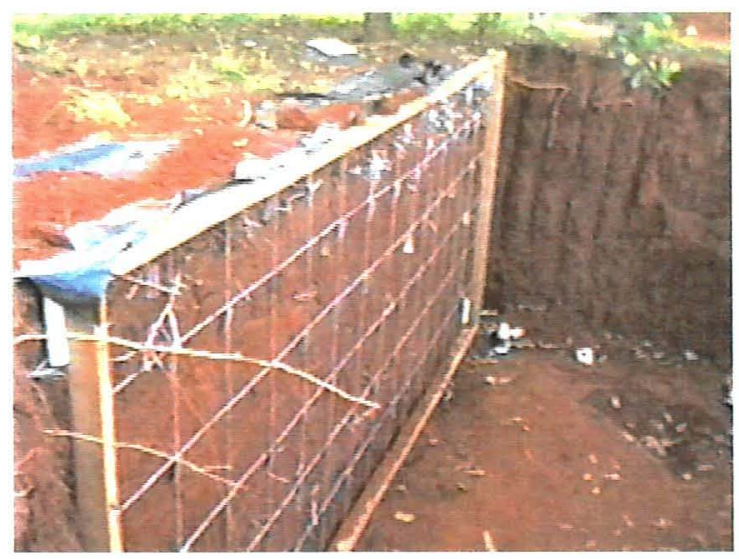

(a)

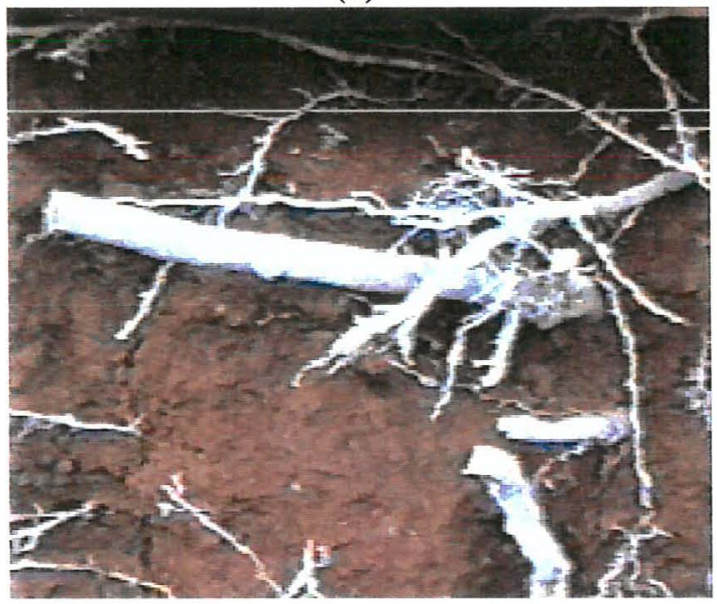

(c)

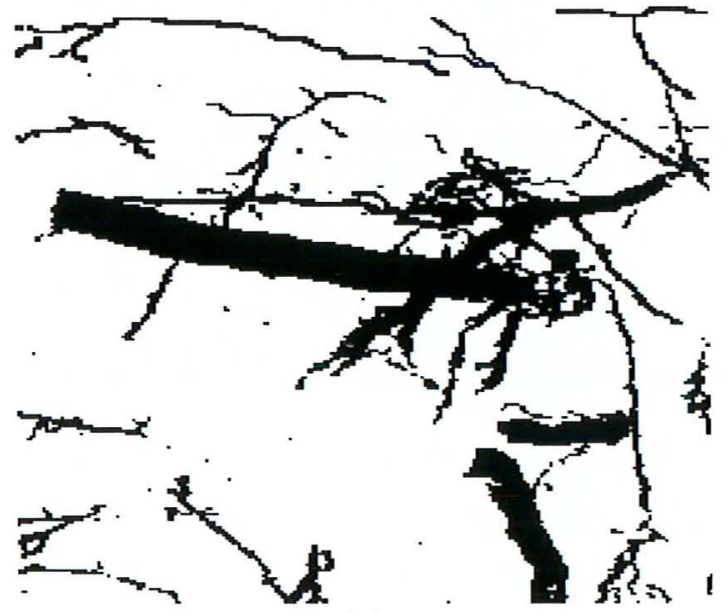

(e)

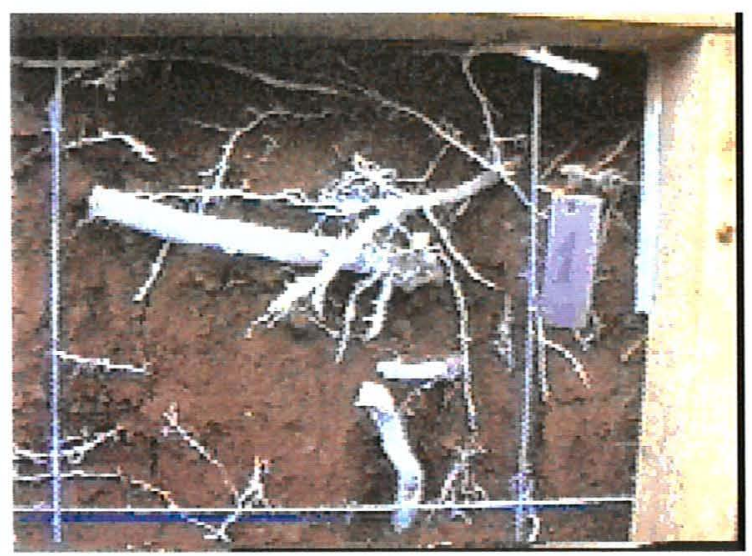

(b)

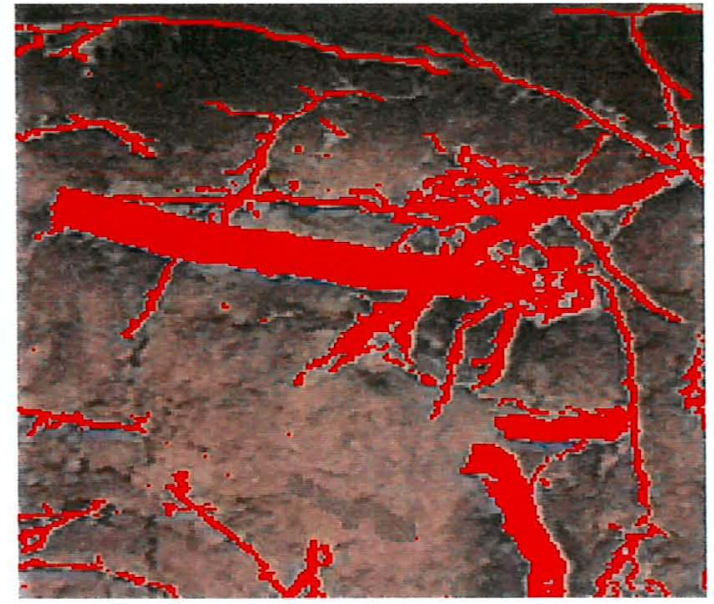

(d)

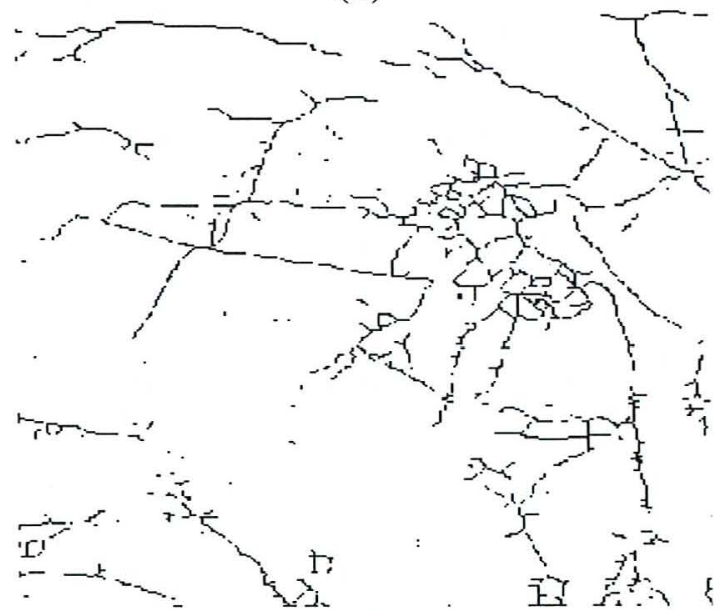

(f)

Figura 2. . a - vista do perfil de solo a ser filmado; b - imagem original; c - imagem recortada com a escala $(25 \times 25 \mathrm{~cm})$; $\mathrm{d}$ - raízes selecionadas; e - processo de binarização da imagem e f - raízes esqueletizadas. 


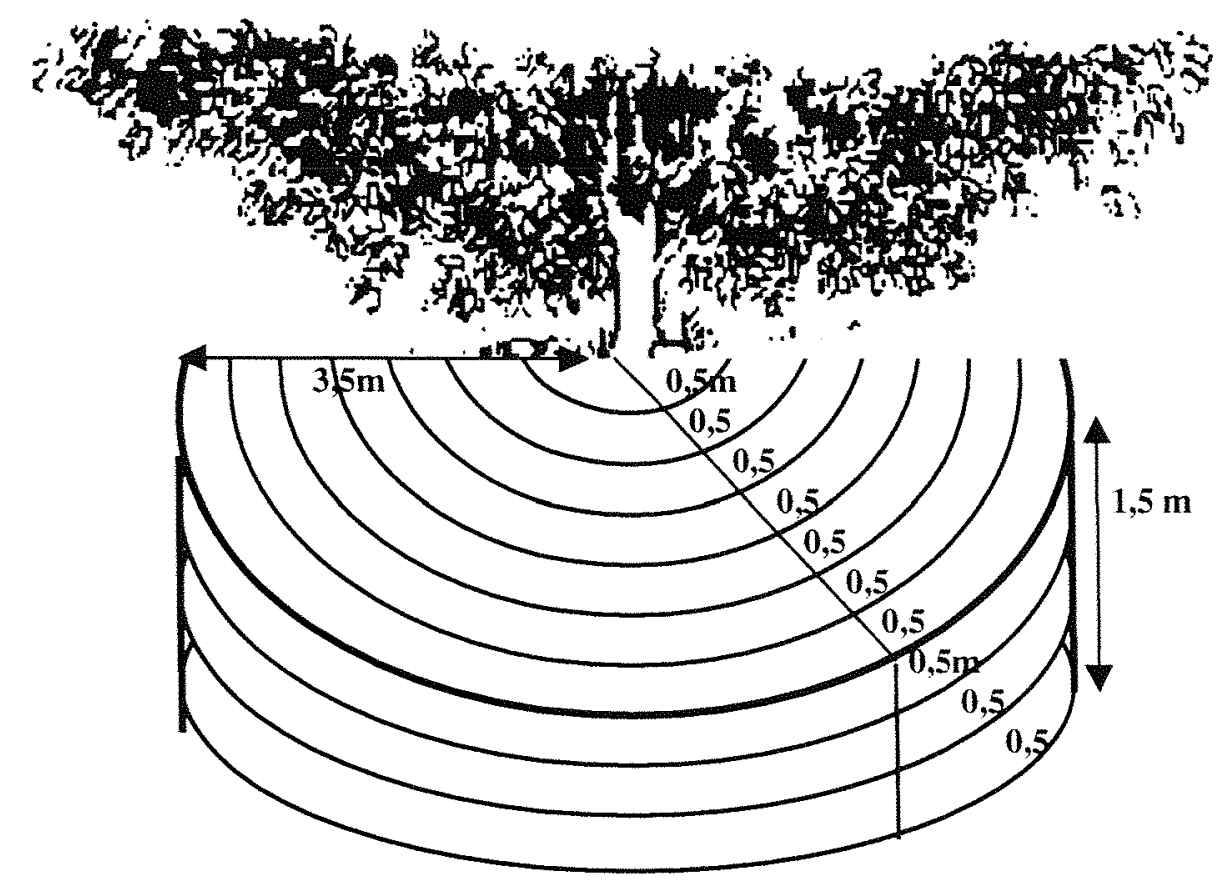

Figura 3. Metodologia dos anéis concêntricos, utilizados na quantificação do volume de solo dos respectivos anéis, em função da distância do tronco e das profundidades analisadas para o estudo da distribuição espacial das raízes.

3.6 Atividade espacial do sistema radicular do limão 'Cravo' em lima ácida 'Tahiti', por meio da variação do conteúdo de água no solo.

Nas duas plantas referentes ao monitoramento da umidade, foram instaladas 13 baterias de tensiômetros, representando $50 \%$ do sistema radicular da planta. A disposição das respectivas áreas de estudo de cada bateria, em relação ao tronco da árvore, é mostrada na Figura 4. Cada bateria é formada por quatro tensiômetros, estando o primeiro a 12,5 centímetros de profundidade, representando a camada de 0 a 25 centímetros; o segundo, a 37,5 centímetros de profundidade, representando a camada de 25 a 50 centímetros; o terceiro. a 62,5 centímetros de profundidade, representando a camada de 50 a 75 centímetros; o quarto, a 87,5 centímetros de profundidade. representando a camada de 75 a 100 centímetros. As distâncias em relação ao tronco da planta foram calculadas em função do centro de cada área, com sua respectiva bateria de tensiômetros. Os valores das respectivas distâncias estão apresentados na Tabela 01. 


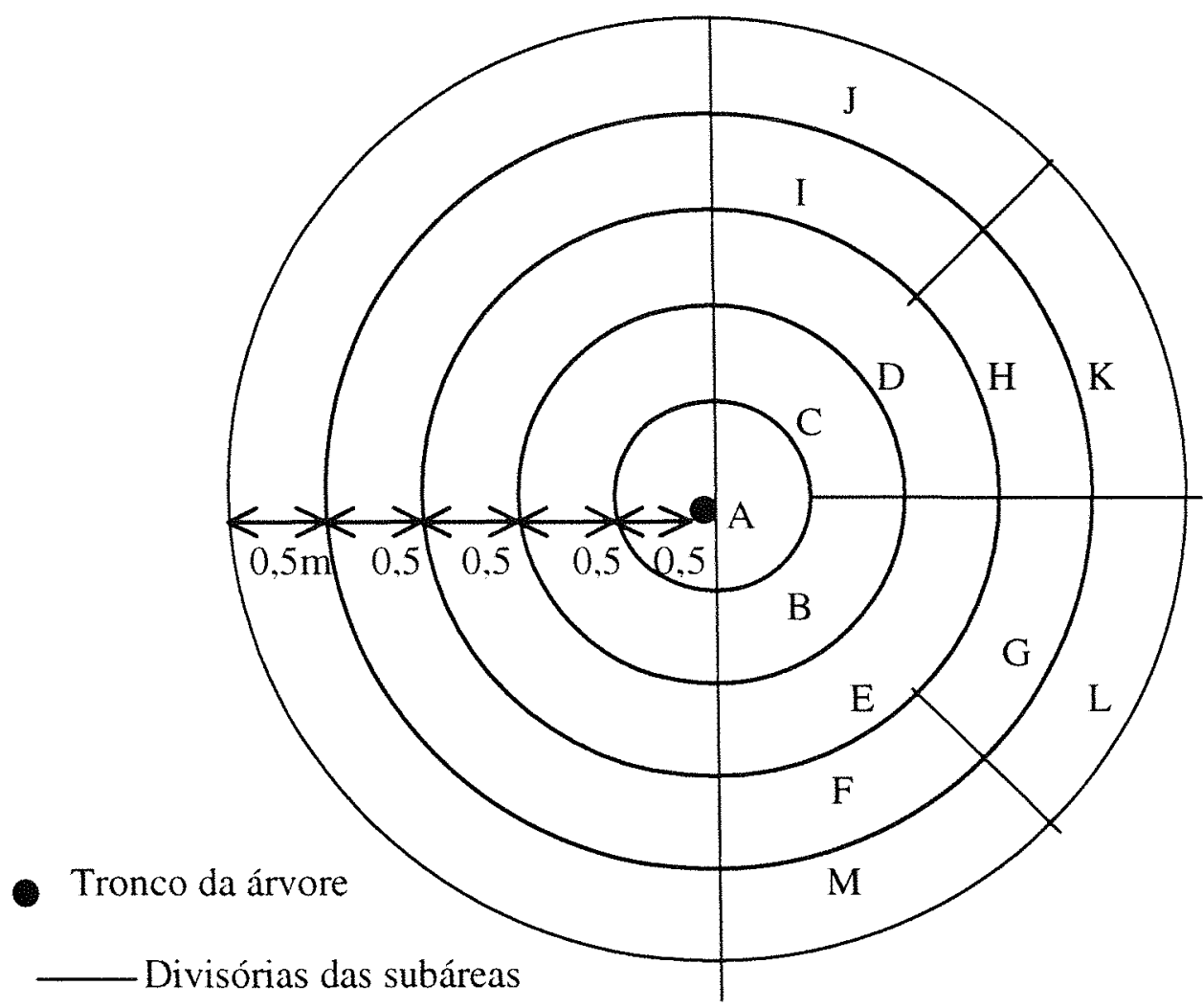

Figura 4. Vista superior das subáreas de estudo das respectivas baterias de tensiômetros. Anéis espaçados em $0.5 \mathrm{~m}$.

Tabela 01: Distâncias do centro de cada subárea até o tronco da árvore.

\begin{tabular}{ccc}
\hline Subáreas & $\begin{array}{c}\text { Distância do centro da } \\
\text { subárea até o tronco da planta }\end{array}$ & $\begin{array}{c}\text { Área das respectivas } \\
\text { subáreas }\left(\mathrm{m}^{2}\right)\end{array}$ \\
\hline A & $0,25 \mathrm{~m}$ & 0,393 \\
B e C & $0,75 \mathrm{~m}$ & 0,589 \\
D e E & $1,25 \mathrm{~m}$ & 0,982 \\
F, G, H e I & $1,75 \mathrm{~m}$ & 0,687 \\
J, L. K e M & $2,25 \mathrm{~m}$ & 0,884 \\
\hline
\end{tabular}


As áreas correspondentes à cada bateria foram calculadas da seguinte forma:

Área $\mathrm{A}$

$$
\begin{array}{lll}
\text { Área A } & \left(\pi * 0,5^{2}\right) / 2 & =0,393 \mathrm{~m}^{2} \\
\text { Área B e C } & \left(\left(\pi * 1^{2}\right)-\left(\pi * 0,5^{2}\right)\right) / 4 & =0,589 \mathrm{~m}^{2} \\
\text { Área D e E } & \left(\left(\pi * 1,5^{2}\right)-\left(\pi * 1^{2}\right)\right) / 4 & =0,982 \mathrm{~m}^{2} \\
\text { Área F, G, H e I } & \left(\left(\pi * 2^{2}\right)-\left(\pi * 1,5^{2}\right)\right) / 8 & =0,687 \mathrm{~m}^{2}
\end{array}
$$$$
\text { Área D e E } \quad\left(\left(\pi * 1,5^{2}\right)-\left(\pi * 1^{2}\right)\right) / 4=0,982 \mathrm{~m}^{2}
$$$$
\text { Área } J, L, K \text { e M } \quad\left(\left(\pi * 2,5^{2}\right)-\left(\pi * 2^{2}\right)\right) / 8=0,884 \mathrm{~m}^{2}
$$

Para selecionar os tensiômetros utilizados no experimento, analisaram-se 173 cápsulas porosas. Foram realizados os testes de condutância e de pressão de borbulhamento. O primeiro mostra a habilidade da cápsula em conduzir líquidos, ou seja, o tempo de resposta do equipamento; já o segundo diz respeito à capacidade da cápsula em suportar pressões próximas a $100 \mathrm{kPa}$.

As cápsulas dos tensiômetros foram previamente saturadas. Em seguida, uniram-se por meio de um tubo flexível os tensiômetros a uma mangueira com 1,10 metro de altura cheia de água. A seguir, as cápsulas foram imersas numa bandeja com água. Com o auxílio de um compressor, aplicou-se uma pressão de ar de 10 mca sobre o menisco superior da mangueira. O equipamento utilizado permitia que 4 tensiômetros fossem testados simultaneamente. Fixaram-se as mangueiras em uma régua de madeira, onde se marcaram dois pontos, tendo o superior, o ponto $1\left(\mathrm{H}_{1}\right)$, altura de 1 metro e o inferior, o ponto $2\left(\mathrm{H}_{2}\right)$, de 0,5 metro. Em seguida, cronometrou-se o tempo que a água demorou para percorrer esse espaço.

De posse desses dados, calculou-se a condutância da cápsula porosa pela seguinte eq. (1).

$$
C=\frac{a * \ln \left(\frac{1000 c c a+H_{1}}{1000 c c a+H_{2}}\right)}{t_{2}-t_{1}}
$$

onde C - condutância hidráulica da cápsula $\left(\mathrm{m}^{2} / \mathrm{s}\right)$

a - área da seção transversal da mangueira de plástico $\left(\mathrm{m}^{2}\right)$

$\mathrm{H}_{1}$ e $\mathrm{H}_{2}$ - carga hidraúlica na cápsula nos tempos $\mathrm{t}_{1}$ e $\mathrm{t}_{2}$ (cm c.a.) 
$t_{1}$ e $t_{2}$ - tempo marcado durante o percurso da água na mangueira (s)

1000 - pressão de ar proveniente do compressor na coluna de água (cm c.a.).

Para a determinação do ponto de borbulhamento, os tensiômetros foram conectados a uma fonte de pressão regulável (compressor). A seguir, a cápsula foi imersa em água, aumentando-se gradualmente a pressão até o início das bolhas de ar. Anotou-se a pressão nesse momento. Para o bom funcionamento do equipamento, a pressão de borbulhonamento não deve ser menor que $100 \mathrm{kPa}$.

De posse dos resultados obtidos, selecionaram-se 120 tensiômetros com o valor da condutância entre $1,0 \times 10^{-4} \mathrm{a} 1,9 \times 10^{-4} \mathrm{~m}^{2} / \mathrm{s}$ e que borbulharam com pressão superior a 100kPa. Logo após, foram cortados e colados novamente nos tamanhos preestabelecidos e novamente testados para verificar a presença de algum tipo de vazamento. Os tensiômetros foram instalados durante o mês de fevereiro de 1999, iniciando-se a coleta dos dados no dia 27/02/99.

No experimento referente à distribuição do sistema radicular, através da variação do conteúdo de água no solo, realizou-se a contabilidade das quantidades de entrada e de saída de água de uma camada de solo que vai da sua superfície até uma profundidade L (balanço de água no solo). Através do plano da superfície do solo, têmse as adições da chuva (P) e/ou irrigação (I), e as perdas por evapotranspiração (ET) e Runoff (RO). Na profundidade L, que deve estar abaixo da zona radicular, podem ocorrer perdas por drenagem profunda (DP) e ganhos por ascensão capilar (AC) da água. A contabilidade de todos esses "componentes" do balanço reflete a quantidade de águà contida na camada de solo, medida através do seu armazenamento (AL). Quando as perdas são maiores que os ganhos, AL diminui e, em caso contrário. AL aumenta. Portanto o balanço de água no solo é importante para o acompanhamento da quantidade de água armazenada. Ela deve ser mantida em níveis ótimos, para maximizar a produtividade agrícola. O balanço hídrico real dá-se conforme a eq. (2).

$$
\mathrm{P}+\mathrm{I}-\mathrm{ET}-\mathrm{RO}-\mathrm{DP}+\mathrm{AC}=\Delta \mathrm{AL}
$$


O balanço real da água no solo é a contabilidade de todas as adições e retiradas de água que realmente ocorrem em dada área utilizada na produção agrícola. Esse balanço mostra a situação hídrica pela qual uma cultura realmente passa e fornece critérios para definir quando e quanto irrigar.

Os períodos foram analisados entre precipitações, para garantir o mesmo teor de água no solo em todo o sistema radicular da planta; verificou-se, que não houve entrada de água (por precipitação ou por irrigação), nem drenagem profunda e ascensão capilar, resultando a eq. (3).

$$
\mathrm{ET}=-\Delta \mathrm{AL}
$$

As leituras do potencial matricial da água no solo foram realizadas nos tensiômetros a cada 24 horas, durante o período da manhã. A leitura no tensiômetro digital de punção é fornecida em milibar (mbar); por isso deve ser transformada em centímetros de coluna de água, para se estimar a umidade atual do solo por subáreas e por camadas de estudo, através da metodologia proposta por van Genüchten (1980) eq. (4).

$$
\theta=\theta_{r} \frac{\theta_{s}-\theta_{r}}{\left(1+\left(\left|\psi_{m}\right| \alpha\right)^{n}\right)^{m}}
$$

onde $\theta$ é a umidade do solo no momento da leitura do potencial mátrico no tensiômetro, $\theta_{\mathrm{s}}$ e $\theta_{\mathrm{r}}$ são umidades volumétricas de saturação e residual, respectivamente, $\psi_{\mathrm{m}}$ módulo potencial matricial $\mathrm{e} \alpha$, m e n são constantes empíricas.

Para a determinação do armazenamento de água no perfil, utilizou-se a metodologia proposta por Saad 1991, conforme a eq. (5).

$$
\mathrm{AL}=\left(\theta_{12,5} \times 250\right)+\left(\theta_{37,5} \times 250\right)+\left(\theta_{62.5} \times 250\right)+\left(\theta_{87,5} \times 250\right)
$$

onde AL é o armazenamento de água no perfil de solo de 0 a $100 \mathrm{~cm}$ de profundidade em milímetros, $\theta_{12.5}, \theta_{37.5}, \theta_{62.5}$ e $\theta_{87.5}$ são os valores de umidade volumétricas a 12,5 ; 
37,$5 ; 62,5$ e $87,5 \mathrm{~cm}$ de profundidade, respectivamente, sendo 250 a faixa de atuação em milímetros, dos respectivos tensiômetros.

$O$ cálculo da variação de armazenamento foi feito em períodos entre precipitações, para a manutenção do mesmo teor de água no solo em todo o sistema radicular da planta. A variação foi calculada com os dados de umidade para cada camada e cada distância em relação ao tronco, utilizando-se a eq. (6).

$$
\Delta \mathrm{AL}=\left(\theta_{\mathrm{f}}-\theta_{\mathrm{i}}\right) \cdot \mathrm{z}
$$

onde $\triangle \mathrm{AL}$ é a variação do armazenamento de água na camada correspondente, $\theta_{\mathrm{f}}$ e $\theta_{\mathrm{i}}$ são umidade final e inicial do respectivo tempo de análise $\left(\mathrm{cm}^{3}\right.$ de água/ $\mathrm{cm}^{3}$ de solo) e $\mathrm{z}$ é a espessura da camada, em milímetros.

A estimativa da atividade radicular (EAR) foi calculada através da razão entre a evapotranspiração da camada ( $E T_{\text {camada }}$ ) e o somatório das evapotranspirações de todas as camadas $\left(\sum \mathrm{ET}_{\text {das camadas }}\right)$ consideradas no estudo, eq. (7).

$$
\operatorname{EAR}(\%)=\frac{E T_{\text {camada }}}{\sum E T_{\text {das camadas }}} \cdot 100
$$

O consumo em litros por camada e subárea foi calculado multiplicando-se a evapotranspiração ( $\mathrm{mm} / \mathrm{dia})$ pela área que cada bateria de tensiômetros representa. 


\subsection{Análise da absorção de água pela planta em diferentes áreas de umedecimento.}

As plantas utilizadas no experimento foram devidamente isoladas, para garantir que as mesmas só tenham recebido água do sistema de irrigação, como pode ser visto na Figura 5 .

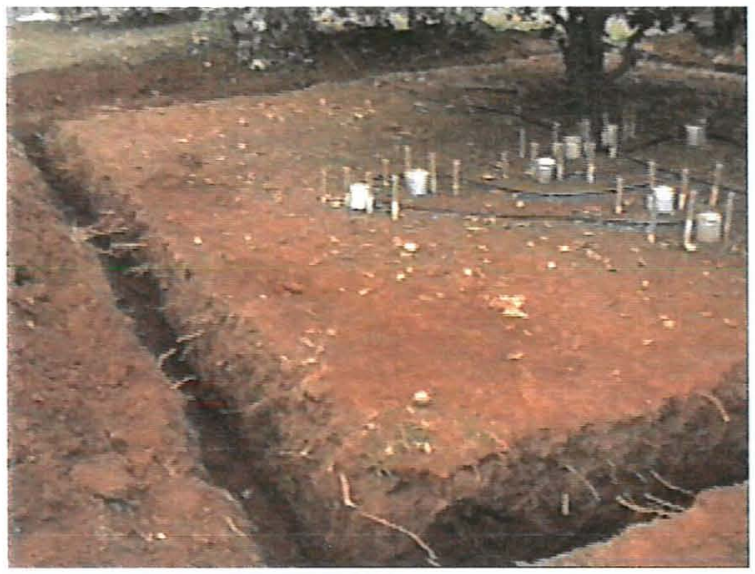

(a)

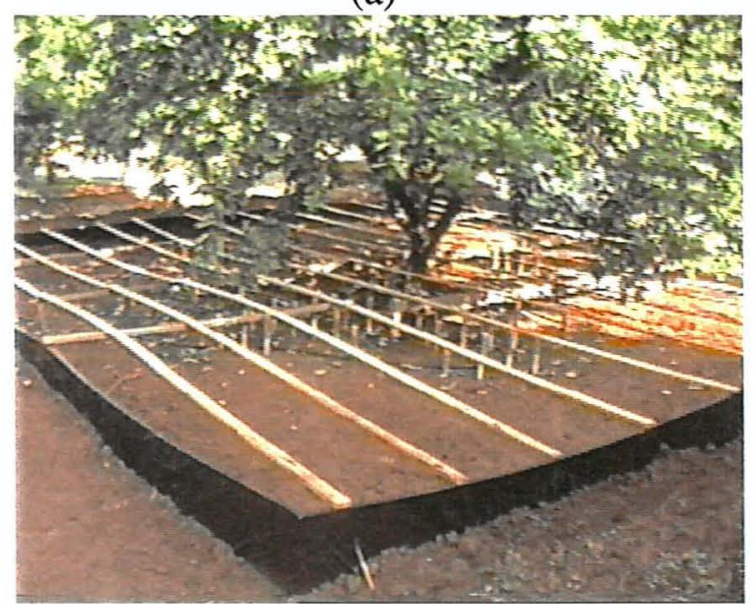

(c)

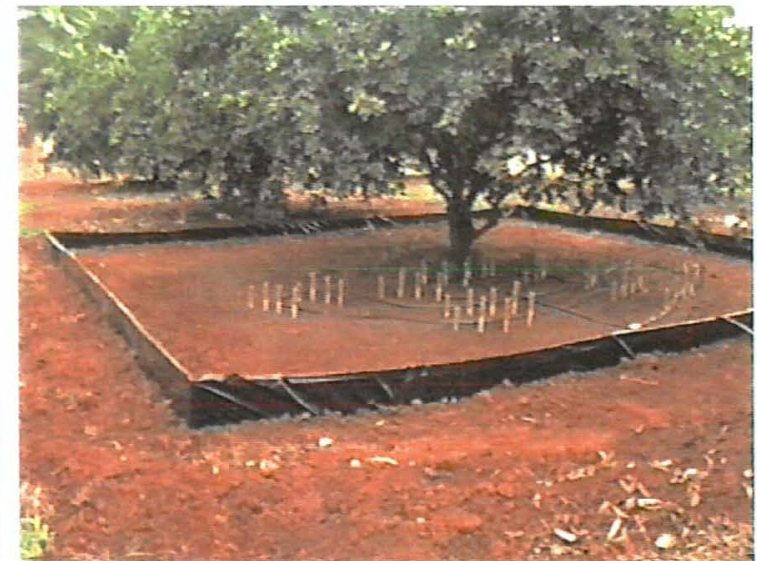

(b)

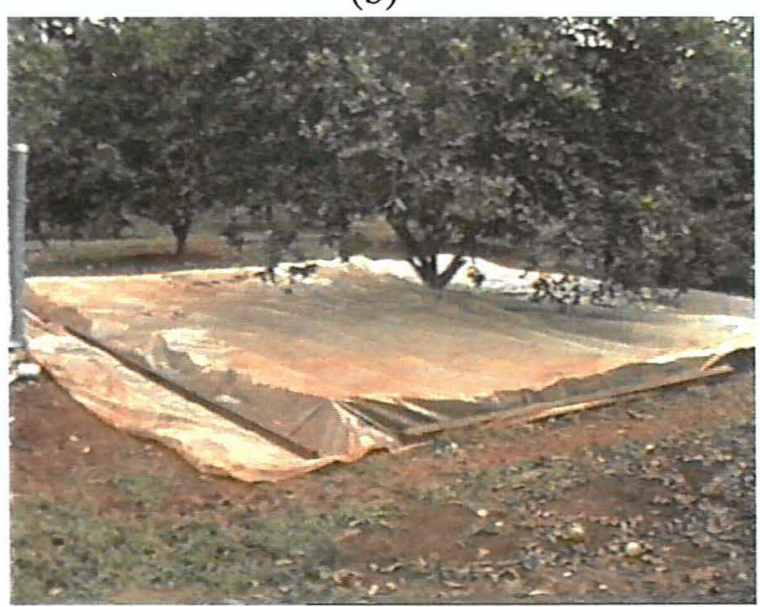

(d)

Figura 5. a- valetas onde foram instaladas lonas pretas até $60 \mathrm{~cm}$ de profundidade; blona preta já instalada e os tensiômetros de punção; c- estrutura de madeira utilizada para sustentar a lona de polietileno e d- planta isolada.

Para medir o consumo de água pela planta, desenvolveu-se úma metodologia que utilizou cápsulas porosas, usadas comumente em filtros caseiros de água potável. Selecionou-se uma cápsula porosa (Pozani), com pressão de borbulhamento de 2 mca e com as seguintes dimensões: $5 \mathrm{~cm}$ de diâmentro por $14 \mathrm{~cm}$ de altura. Com as cápsulas, porosas construíram-se os supertensiômetros de carga constante, cuja função foi fornecer 
água para as plantas. Eles foram ligados a um reservatório de água, construído com tubo de pvc azul, de $100 \mathrm{~mm}$ de diâmetro; tais reservatórios tiveram que funcionar como um tubo de Mariotte, para que fosse possível controlar a carga hidráulica exercida no centro da cápsula porosa do supertensiômetro de carga constante.

As barras de pvc de $100 \mathrm{~mm}$ foram cortadas em barras de $2 \mathrm{~m}$ de comprimento e a parte inferior do reservatório foi vedada com um cap. A saída de água do reservatório para o supertensiômetro de carga constante foi instalada a $30 \mathrm{~cm}$ de altura. $\mathrm{Na}$ face externa do tubo, instalou-se uma mangueira cristal, desde a parte superior até a inferior do tubo, para monitorar o nível da água no reservatório. No cap da parte superior do reservatório, colaram-se dois tubos de acrílico de $1,4 \mathrm{~cm}$ de diâmetro, utilizados para encher o reservatório de água: para o funcionamento do tubo de Mariotte, são vedados com rolhas de borracha, utilizadas em tensiômetros de punção. Furou-se, ainda, o cap e colocou-se uma mangueira cristal no interior do tubo, fazendo com que ela fosse o nível de referência para o tubo de Mariotte, (Figuras 6 e 7).

A saída de água e as conexões para a instalação da mangueira de monitoramento foram feitas com tubo de cobre e coladas com cola araldite 24 horas. A vedação do tubo que fez funcionar o Mariotte foi feita com silicone, para, quando fosse necessário mudar a carga hidráulica, facilitar o seu funcionamento, retirando o silicone e colocando a mangueira na posição correta. vedando-se novamente o tubo com silicone.

O consumo de água foi medido diretamente no reservatório: enchia-se o tubo com água até um determinado ponto demarcado; em seguida. fechava-se o reservatório com as rolhas de tensiômetros de punção e, com uma seringa de $60 \mathrm{ml}$ de volume, retirava-se o ar de dentro do tubo pelas rolhas de tensiômetros de punção, acionando o tubo de Mariotte. No dia seguinte, uma certa quantidade de água saía para o solo, abaixando o nível dentro do reservatório; pela mangueira cristal, instalada na lateral do tubo. marcava-se o nível da água no dia. Media-se a distância entre o ponto anteriormente demarcado e o nível da água no dia seguinte. e calculava-se o volume de água fornecido para a planta em cada dia. 


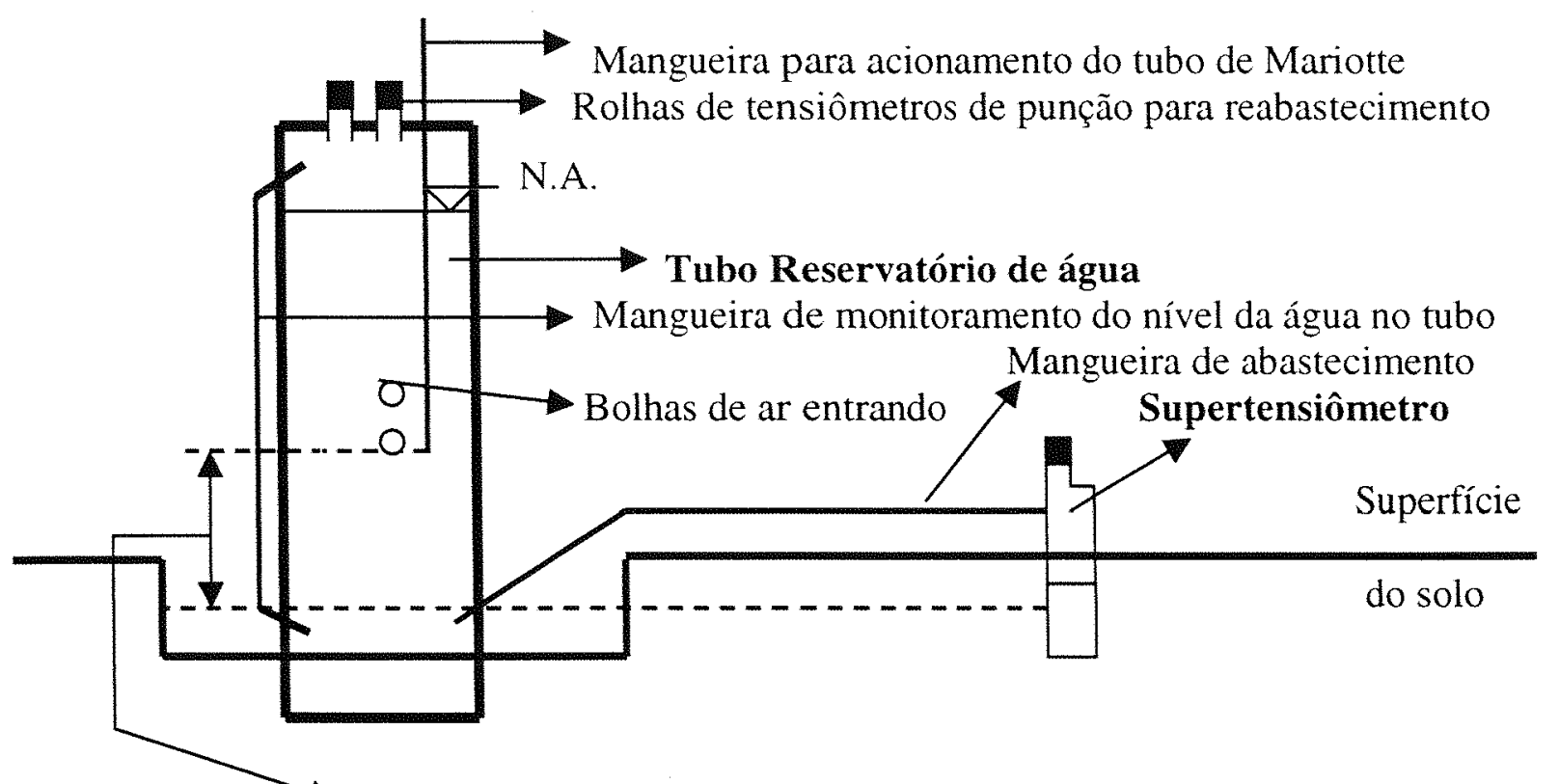

Carga hidráulica exercida no centro da cápsula

Figura 6. Esquema de funcionamento da metodologia proposta para medir o consumo de água pela planta.

Em testes preliminares com a metodologia. colocou-se o equipamento para funcionar, porém com carga hidráulica negativa, ou seja, o tubo que fazia o Mariotte funcionar estava $10 \mathrm{~cm}$ abaixo do centro da cápsula do supertensiômetro de carga constante. Dessa forma, se fez o monitoramento do tamanho do bulbo molhado, percebeu-se ser ele pequeno (diâmetro aproximado de $10 \mathrm{~cm}$ ) e que seria necessário um número maior de supertensiômetros de carga constante para que a área molhada pelo sistema fosse a ideal. Com isso, passou-se a operar o sistema com uma determinada carga hidráulica positiva nas cápsulas, visando a aumentar o tamanho do bulbo molhado.

Para o experimento, foram construídos e testados 30 tubos reservatórios e 100 supertensiômetros de carga constante, estes últimos foram instalados em anéis eqüidistantes de 0.7 metro uns dos outros, ou seja, nas distâncias de 0,70;1,40;2.10 e 2,80 metros do tronco, e espaçados em 0,60 metro entre os supertensiômetros na linha. Na planta 1. instalaram-se 63 supertensiômetros, distribuídos em toda a área de projeção da copa. segundo o critério preestabelecido. Já na planta 2, instalaram-se 32 supertensiômetros, distribuídos em $50 \%$ da área de projeção da copa. 


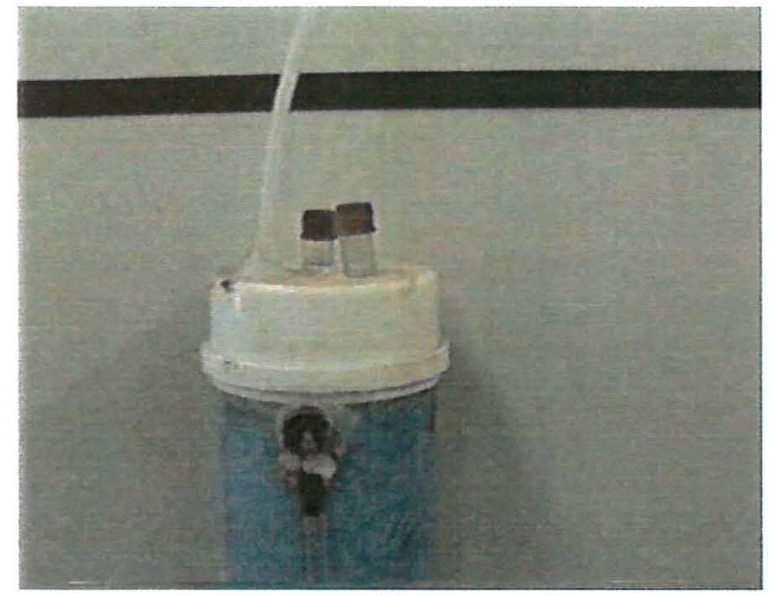

(a)

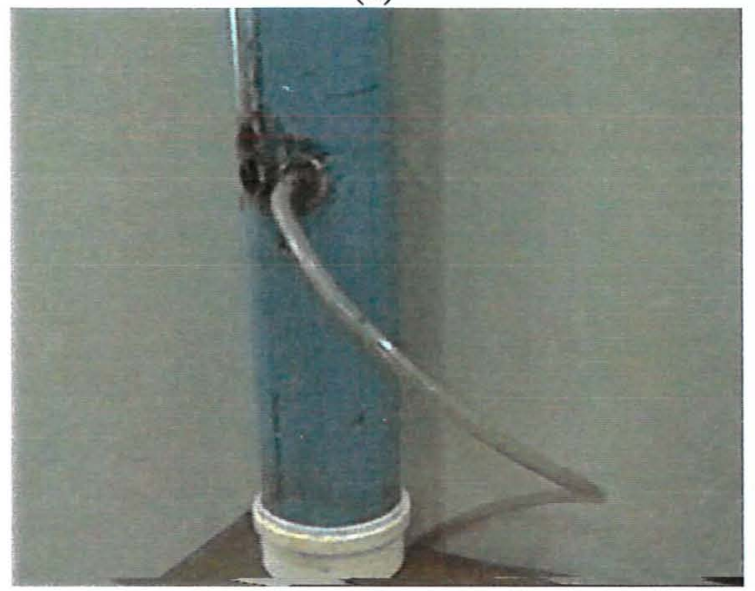

(c)

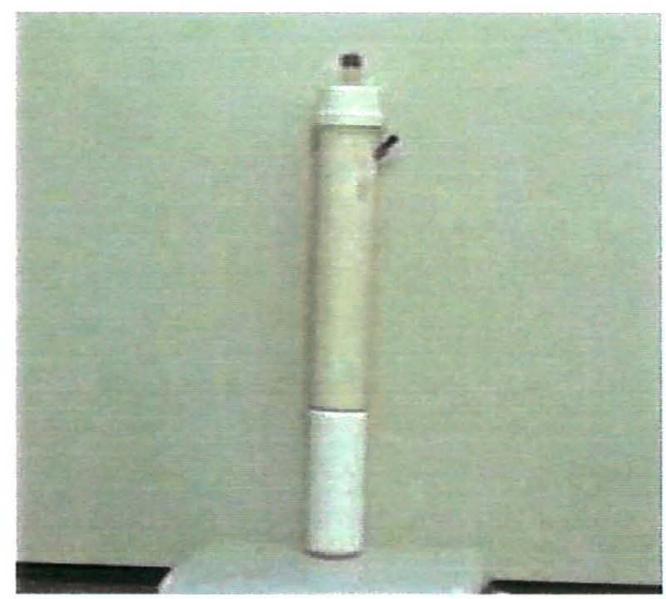

(b)

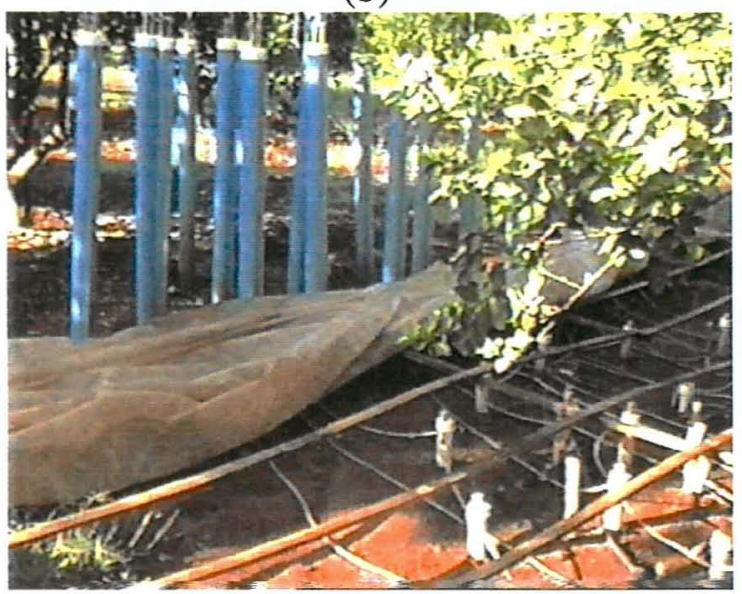

(d)

Figura 7. a- detalhe do cap superior; b-supertensiômetro de carga constante; c- detalhe da saída do reservatório e d- tubos reservatórios instalados no campo.

Foram instalados 15 tubos reservatórios em cada planta. Os supertensiômetros de carga constante foram ligados em série, ou seja, de 3 até 5 unidades em cada tubo reservatório, mantendo-se a mesma distância dos supertensiômetros, pertencentes ao mesmo grupo, em relação ao tronco da planta (Figura 8).

O monitoramento do tamanho do bulbo molhado foi feito com tensiômetros de punção, instalados da seguinte forma: distância do supertensiômetro de carga constante de 10, 20, 30 e 40 cm; para cada distância, instalaram-se em 6 profundidades, a saber10, 20, 30, 40, 50 e $60 \mathrm{~cm}$. (Figura 9). Esse monitoramento foi realizado em apenas um 
bulbo molhado, pois não estava previsto que haveria necessidade de se efetuar essa medição. Analisando-se o consumo de água no bulbo monitorado, verificou-se que era semelhante ao consumo das demais cápsulas; daí concluiu-se que os bulbos molhados não deviam estar variando de tamanho.

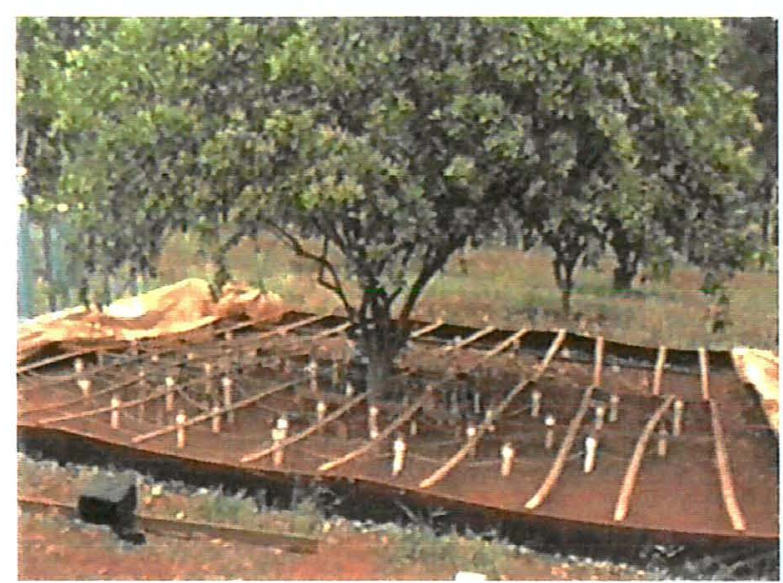

(a)

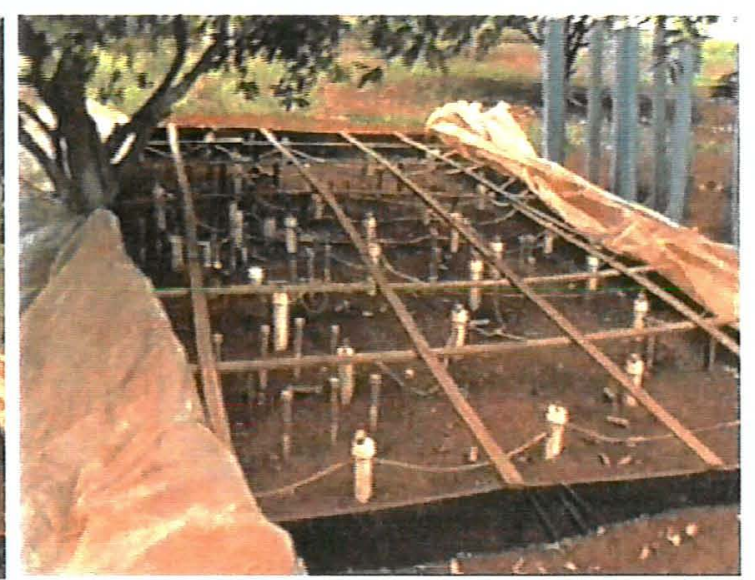

(b)

Figura 8. a- planta 1, 64 supertensiômetros de carga constante, $100 \%$ projeção da copa e b- planta 2, 32 supertensiômetros de carga constante, $50 \%$ projeção da copa.

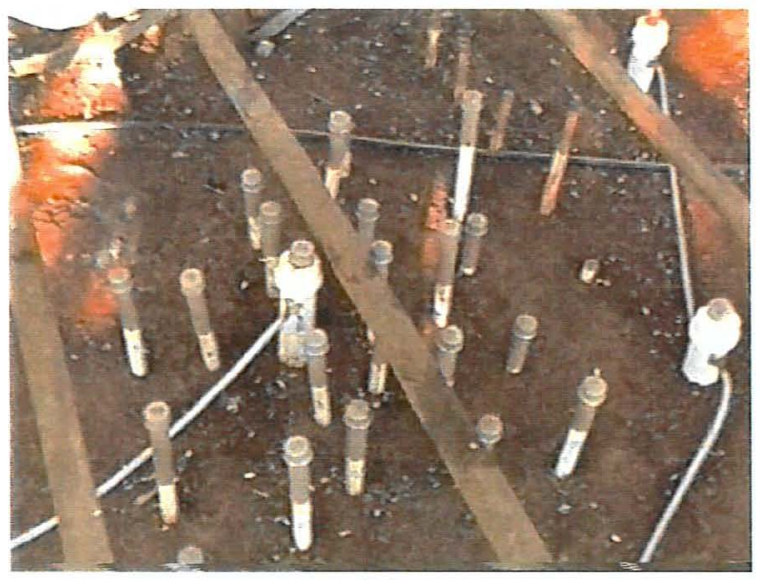

(a)

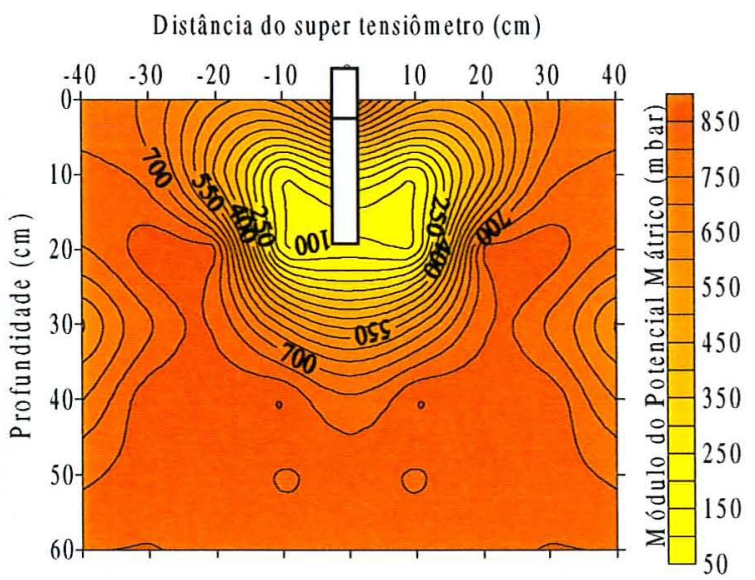

(b)

Figura 9. a- posição dos tensiômetros de punção ao redor do supertensiômetro de carga constante e b- visualização gráfica do bulbo molhado, através das leituras dos tensiômetros de punção. 
Observando-se os resultados obtidos nas análises de distribuição do sistema radicular, verificou-se que a maior parte da extração de água pela planta estava na primeira camada de solo $(0-25 \mathrm{~cm})$, resultado confirmado pelas imagens digitalizadas, segundo elas cerca de $60 \%$ das raízes se concentraram na primeira camada de solo. Com isso instalaram-se os supertensiômetros de carga constante, com o centro da cápsula porosa a $12,5 \mathrm{~cm}$ de profundidade, ou seja, no centro da camada de solo que apresentou maior quantidade de raízes.

O experimento foi instalado no dia 25 de agosto, e, até o dia 7 de setembro, o sistema operou com carga hidráulica negativa; a partir de desta data até 7 de outubro, o equipamento trabalhou com carga hidráulica positiva de $10 \mathrm{~cm}$. Já para o período de 7 de outubro a 3 de dezembro, a carga hidráulica foi de $40 \mathrm{~cm}$. Analisando os resultados, observou-se que, mesmo com carga hidráulica de $40 \mathrm{~cm}$, o bulbo molhado continuou pequeno (diâmetro aproximado de $30 \mathrm{~cm}$ ).

\subsubsection{Estimativa do consumo de água pelas plantas do pomar.}

Quando se avalia a necessidade hídrica de uma dada cultura, há que se pensar na determinação da evapotranspiração da cultura (ETm), devido à sua grande importância nos projetos e no manejo da irrigação. Um dos métodos mais utilizados é o proposto pela FAO, Boletim 24, o qual relaciona a evapotranspiração de referência a um grupo de coeficientes empíricos de cultura $(\mathrm{Kc})$. Como tal método se baseia em parâmetros ou dados relativamente fáceis de obter, ele é considerado uma técnica prática. Uma das suas principais limitações, todavia, é que no Brasil, ocorre uma falta de informações dos diferentes valores de Kc, para as diversas condições de solo, de clima, de manejo, cultura etc.. Os valores fornecidos pela FAO representam somente as regiões áridas, o que difere das principais regiões produtoras de limão no Brasil. Estudos realizados em Limeira-S.P., por Vieira e Ribeiro (1993), determinaram para as condições climáticas da região os coeficientes de cultura Kc, para a lima ácida 'Tahiti'. no espaçamento de $7 \times 5 \mathrm{~m}$,com 3,5 anos, nas diferentes épocas do ano. Utilizou o tanque classe A para a obtenção dos valores de evapotranspiração de referência ETo. Os 
Quadros 1 e 2 mostram os coeficientes de cultura citados pela FAO e por Vieira e Ribeiro (1993). Outros métodos vêm sendo utilizados em citros, para a determinação das necessidades hídricas das culturas, como o pulso de calor na determinação do fluxo de seiva, ou, indiretamente, a evapotranspiração da cultura, o balanço hídrico da água no solo. Usando modelos com base em elementos micrometereológicos e em parâmetros biométricos, o mais utilizado é o de Penman-Monteith.

Quadro 1. Coeficientes de cultura para citros para zonas subtropicais com chuva de inverno, citados por Doorenbos \& Kassam (1994).

Quadro 2. Coeficientes de cultura para os respectivos estados vegetativos da cultura do limão "Tahiti", para o Estado de São Paulo, citado por Vieira e Ribeiro (1993).

\begin{tabular}{ccc}
\hline Mês & Estado Vegetativo da cultura & Kc \\
\hline Jan. & Pomar em plena produção & 0,76 \\
Fev. & Final de produção & 0,77 \\
Mar. & Início da florada & 0,90 \\
Abr. & Fase de frutificação & 0,61 \\
mai. & Frutificação e produção & 0,90 \\
Jun. & Produção & 0,73 \\
Jul. & Produção & 0,70 \\
Ago. & Término da colheita & 0,72 \\
Set. & Brotação & 0,73 \\
Out. & Florada & 0,79 \\
Nov. & Florada e frutificação & 0,84 \\
Dez. & Produção & 0,80 \\
\hline
\end{tabular}

Em 1990, numa reunião da FAO. conclui-se que o método de Penman-Monteith é o mais adequado para estimar a evapotranspiração de uma cultura em escala diária. A partir daí. o consumo de água pelas plantas passou a ser calculado com base na 
evapotranspiração de referência, estimada pelo método de Penman-Monteith. Concluiuse, ainda, que o método necessitava de algumas parametrizações, o que foi executado, permitindo que o mesmo fosse apresentado na forma abaixo citada (Pereira et al., 1997). Utilizaram-se os dados da estação meteorológica automática do Departamento de Física e Meteorologia da ESALQ, para os cálculos da ETo.

Pressão de saturação: es $(\mathrm{kPa})=0,6108 \cdot 10^{\left(\frac{7,5 . \mathrm{T}}{237.3+\mathrm{T}}\right)}$

sendo $\mathrm{T}$ - temperatura média diária ${ }^{\circ} \mathrm{C}$;

Pressão de vapor atual: ea $(\mathrm{kPa})=\frac{\text { UR.es }}{100}$

UR - umidade relativa média do dia \%;

Déficit de Saturação: $\Delta \mathrm{e}(\mathrm{kPa})=\mathrm{es}-\mathrm{ea}$

Declividade da curva de pressão de vapor: $\mathrm{s}=\frac{4098 . \mathrm{es}}{(\mathrm{T}+237,3)^{2}}$

Constante psicrométrica modificada: $\gamma_{\mathrm{M}}=\gamma\left(1+0,33 . \mathrm{U}_{2}\right)$

$\gamma$ - constante psicrométrica;

$\mathrm{U}_{2}$ - velocidade do vento a 2 metros de altura m.s ${ }^{-1}$;

Evapotranspiração de referência:

ETo $(\mathrm{mm} / \mathrm{dia})=\left(\frac{\mathrm{s}}{\mathrm{s}+\gamma_{\mathrm{M}}} \cdot \frac{0,574 \cdot \mathrm{Qg}}{\lambda}\right)+\left(\frac{\gamma}{\mathrm{s}+\gamma_{\mathrm{M}}} \cdot \frac{900}{\mathrm{~T}+275} \cdot \mathrm{U}_{2} \cdot \Delta \mathrm{e}\right)$

onde: $\gamma$ - coeficiente psicrométrico, $0,0622 \mathrm{kPa} .{ }^{\circ} \mathrm{C}^{-1}$;

$\lambda$ - calor latente de evaporação $2,45 \mathrm{MJ} . \mathrm{Kg}^{-1}$;

Qg - radiação global, MJ.m ${ }^{-2} \cdot \mathrm{d}^{-1}$. 
Para transformar os resultados de evapotranspiração de referência em evapotranspiração da cultura, utilizaram-se os coeficientes de cultura proposto por Vieira e Ribeiro (1993) (Quadro 2).

O procedimento utilizado para a correção da ETc pelo efeito da localização foi o proposto por Keller e citado por Pizarro (1996), que se baseia na fração da superfície de projeção da copa da planta pela superfície total disponível para a planta.

$$
\begin{aligned}
& \mathrm{A}=\frac{\text { Área de projeção da copa }}{\text { Área total do espaçamento de plantio }} \\
& \mathrm{Kr}=\mathrm{A}+0,15 \cdot(1-\mathrm{A})
\end{aligned}
$$

O diâmetro médio de copa das plantas do pomar estavam em torno de 5,6 metros e o espaçamento de plantio é de $8 \mathrm{~m} \times 7 \mathrm{~m}$. Aplicando estes valores nas equações acima encontra-se um valor de $\mathrm{Kr}$ de 0,52 . Com isso tem-se a equação para estimativa da evapotranspiração da cultura, eq. (15).

$$
\mathrm{ETc}(\mathrm{mm} / \mathrm{dia})=\mathrm{ETo} \cdot \mathrm{Kc} \cdot \mathrm{Kr}
$$

Como o sistema de medição do consumo de água pela planta, proposto no trabalho, fornece os dados em litros consumidos diariamente, o volume absorvido (L/dia), convertemos a ETc em volume de água demandado pela planta diariamente, multiplicando a ETc pela área de projeção da copa da planta. O resultado foi expresso em $L$ dia, ou seja. o volume estimado de irrigação. 


\section{RESULTADOS E DISCUSSÃO}

\subsection{Características do solo.}

As amostras de solo indeformadas foram coletadas nas árvores vizinhas às escolhidas para o experimento. Para cada camada de solo em estudo foram coletadas cinco amostras. Estas foram previamente saturadas e, em seguida. colocadas na mesa de tensão, passando pelos pontos de 1,2 e $4 \mathrm{kPa}$. Na seqüência, encaminharam-se as amostras para os extratores de placa, passando pelos pontos de 10, 30, 50, 100, $500 \mathrm{e}$ $1500 \mathrm{kPa}$. Com os resultados obtidos, ajustou-se a equação de van Genuchten (1980) para cada amostra, através do programa SWRC (Dourado Neto ,1996) cujos parâmetros são apresentados na Tabela 2; as curvas de retenção com melhor ajuste para cada profundidade constituem a Figura 10.

$\mathrm{Na}$ Tabela 3, encontram-se os resultados da composição granulométrica e da densidade aparente por camadas de solo. Observa-se que a classe textural, nas 4 profundidades analisadas, foi "argilosa" e a densidade média do solo, próxima de 14,0 $\mathrm{kg} / \mathrm{m}^{3}$, o que indica um ligeiro grau de compactação do terreno.

As equações de condutividade hidráulica, em função do módulo do potencial mátrico $(K(h))$, a partir de ensaios de campo, e usando o método do perfil instantâneo, foram realizadas na área vizinha ao pomar, por Medeiros (1998), utilizando baterias de tensiômetros, nas profundidades de 10,30,50 e $70 \mathrm{~cm}$. A equação de $\mathrm{K}(\mathrm{h})$ foi obtida por uma simplificação do procedimento de Hillel et al. (1972), sugerida por Libardi (1995), que utiliza a variação de armazenamento de água com o tempo de redistribuição. A umidade do solo foi estimada pelas curvas de retenção, obtidas para cada profundidade e cada local dos testes. Os parâmetros da equação de condutividade. 
obtidos para as profundidades de 20,40 e $60 \mathrm{~cm}$, estão apresentados na Tabela 4 e na Figura 11.

Tabela 2. Valores de $n, m, \theta_{S}, \theta_{R}, \alpha$ e coeficiente de ajuste da curva de retenção de água no solo, para as diferentes profundidades.

\begin{tabular}{|c|c|c|c|c|c|c|}
\hline \multirow{2}{*}{\multicolumn{2}{|c|}{ Camadas }} & \multicolumn{5}{|c|}{ Amostras } \\
\hline & & 1 & 2 & 3 & 4 & 5 \\
\hline \multirow{6}{*}{$0-25$} & $\mathrm{n}$ & 3,8000 & 3,5256 & 1,7522 & 1,8532 & 3,9058 \\
\hline & $\mathrm{m}$ & 0,0536 & 0,0778 & 0,0682 & 0.0176 & 0,0535 \\
\hline & $\theta_{\mathrm{S}}$ & 0.5220 & 0,5800 & 0.5160 & 0,6180 & 0,5160 \\
\hline & $\theta_{\mathrm{R}}$ & 0,2310 & 0.2500 & 0,1720 & 0,0005 & 0,2330 \\
\hline & $\alpha$ & 0,4443 & 0,6285 & 0.5504 & 0,1471 & 0,3268 \\
\hline & Coef. A just & 0.9950 & 0.9930 & 0.9960 & 0.9830 & 0,9960 \\
\hline \multirow{6}{*}{$25-50$} & $\mathrm{n}$ & 1,0409 & 1,0349 & 1,0360 & 1,0350 & 2,1550 \\
\hline & $\mathrm{m}$ & 0,0392 & 0,0337 & 0,0347 & 0,0338 & 0,0584 \\
\hline & $\theta_{\mathrm{s}}$ & 0.5381 & 0,5035 & 0.5346 & 0.5141 & 0,5430 \\
\hline & $\theta_{R}$ & 0,0002 & 0,0007 & 0,0007 & 0,0006 & 0,3300 \\
\hline & $\alpha$ & 0,3507 & 0,2270 & 0,1438 & 0,1017 & 0,9729 \\
\hline & Coef. A just & 0.9970 & 0,9910 & 0,9960 & 0.9950 & 0,9910 \\
\hline \multirow{6}{*}{$50-75$} & $\mathrm{n}$ & 1,0254 & 1,0444 & 1,0365 & 1,1396 & 1,0303 \\
\hline & $\mathrm{m}$ & 0,0248 & 0,0425 & 0,0352 & 0,1225 & 0,0294 \\
\hline & $\theta_{\mathrm{S}}$ & 0,5178 & 0,5431 & 0,5308 & 0,5606 & 0,5141 \\
\hline & $\theta_{\mathrm{R}}$ & 0,0008 & 0.0006 & 0,0005 & 0,3113 & 0,0006 \\
\hline & $\alpha$ & 0,2244 & 1,1269 & 0,0322 & 0.2448 & 0,1632 \\
\hline & Coef. A just & 0.9800 & 0,9950 & 0.9920 & 0.9860 & 0,9920 \\
\hline \multirow{6}{*}{$75-100$} & $\mathrm{n}$ & 1,0386 & 1.0404 & 1,0491 & 1.1117 & 1,1273 \\
\hline & $\mathrm{m}$ & 0,0372 & 0,0388 & 0,0468 & 0,1005 & 0,1129 \\
\hline & $\theta_{\mathrm{s}}$ & 0,5381 & 0,5320 & 0,5160 & 0,5591 & 0,5284 \\
\hline & $\theta_{\mathrm{R}}$ & 0,0003 & 0,0001 & 0,0008 & 0,2577 & 0,3393 \\
\hline & $\alpha$ & 0,1713 & 0.1288 & 0,0370 & 0,2668 & 0,3987 \\
\hline & Coef. A just & 0.9860 & 0.9980 & 0.9840 & 0,9930 & 0,9900 \\
\hline
\end{tabular}

Tabela 3. Composição granulométrica e densidade aparente da área experimental.

\begin{tabular}{ccccc}
\hline $\begin{array}{c}\text { Profundidades } \\
\mathrm{cm}\end{array}$ & $\begin{array}{c}\text { Argila } \\
\%\end{array}$ & $\begin{array}{c}\text { Silte } \\
\%\end{array}$ & $\begin{array}{c}\text { Areia } \\
\%\end{array}$ & $\begin{array}{c}\text { Densidade } \\
\mathrm{kg} / \mathrm{m}^{3}\end{array}$ \\
\hline $0-25$ & 47,60 & 20,59 & 31,81 & 14,4 \\
$25-50$ & 58,14 & 2,85 & 39,01 & 14,6 \\
$50-75$ & 61,62 & 15,01 & 23,37 & 14,1 \\
$75-100$ & 63.64 & 11.80 & 24.57 & 13.7 \\
\hline
\end{tabular}


Tabela 4. Parâmetros da equação ${ }^{*}$ de condutividade hidráulica, em função do módulo do potencial mátrico da água do solo, para as profundidades de 20, 40 e $60 \mathrm{~cm}$.

\begin{tabular}{ccccccc}
\hline & Prof.=20 & \multicolumn{3}{c}{ Prof.=40 } & Prof.=60 \\
Repetição & $\mathbf{a}$ & $\mathbf{b}$ & $\mathbf{a}$ & $\mathbf{b}$ & $\mathbf{a}$ & b \\
\hline $\mathbf{1}$ & 22000000 & $-3,8$ & 147000000 & $-3,86$ & 93300000 & $-3,68$ \\
$\mathbf{2}$ & 15300 & $-2,43$ & 17400 & $-2,23$ & 682000 & $-3,44$ \\
$\mathbf{3}$ & 139000 & $-3,11$ & 85200 & $-2,71$ & 6950000 & $-3,81$ \\
\hline
\end{tabular}

* $\mathrm{K}(\mathrm{h})=\mathrm{ah}^{\mathrm{b}}$ sendo $\mathrm{K}(\mathrm{h})$ - condutividade hidráulica $\left(\mathrm{mm} \cdot \mathrm{dia}^{-1}\right)$

a, b - constantes de ajuste

h - módulo do potencial mátrico (cm c.a.)

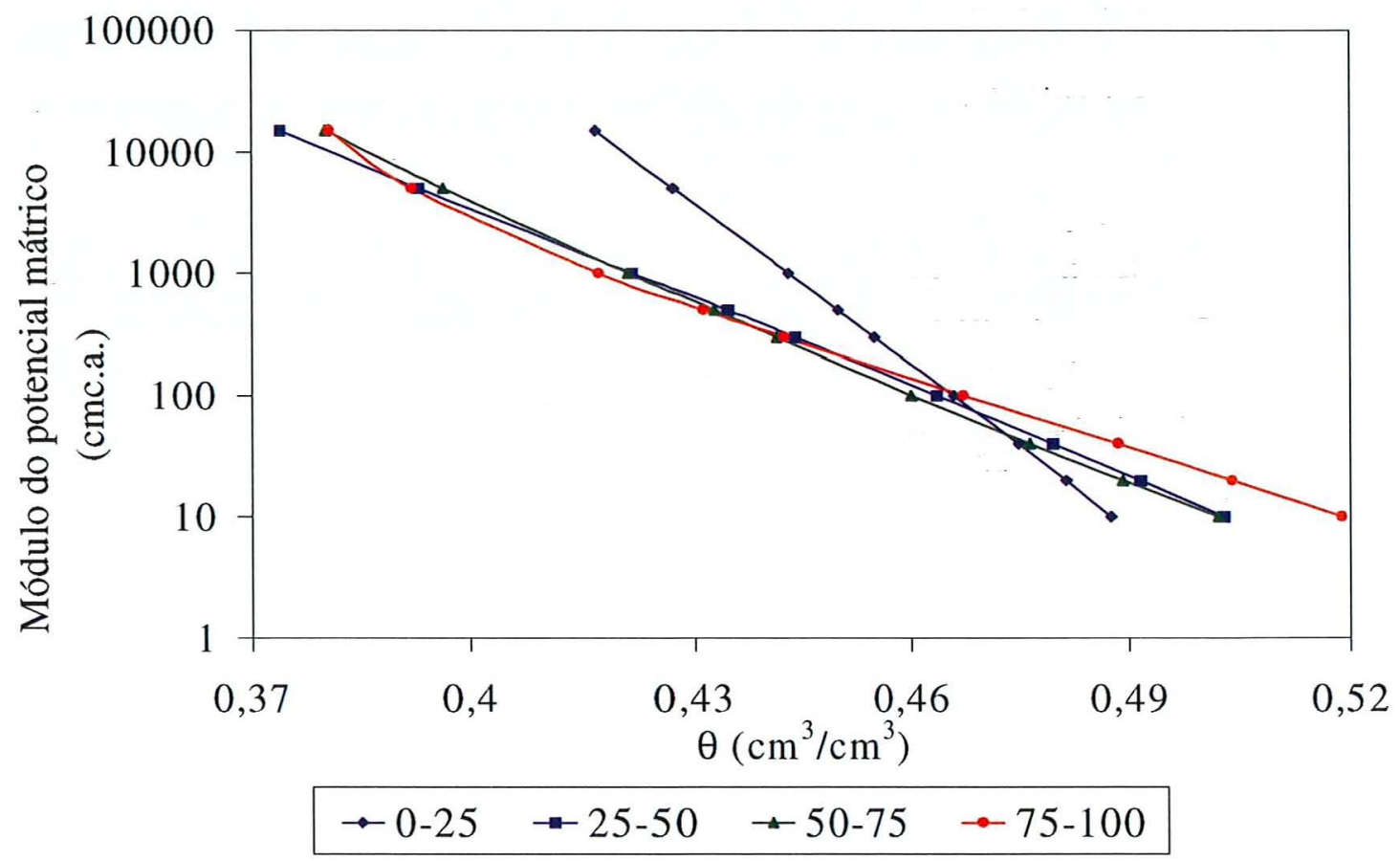

Figura 10. Curvas de retenção para as quatro camadas de solo em estudo. 


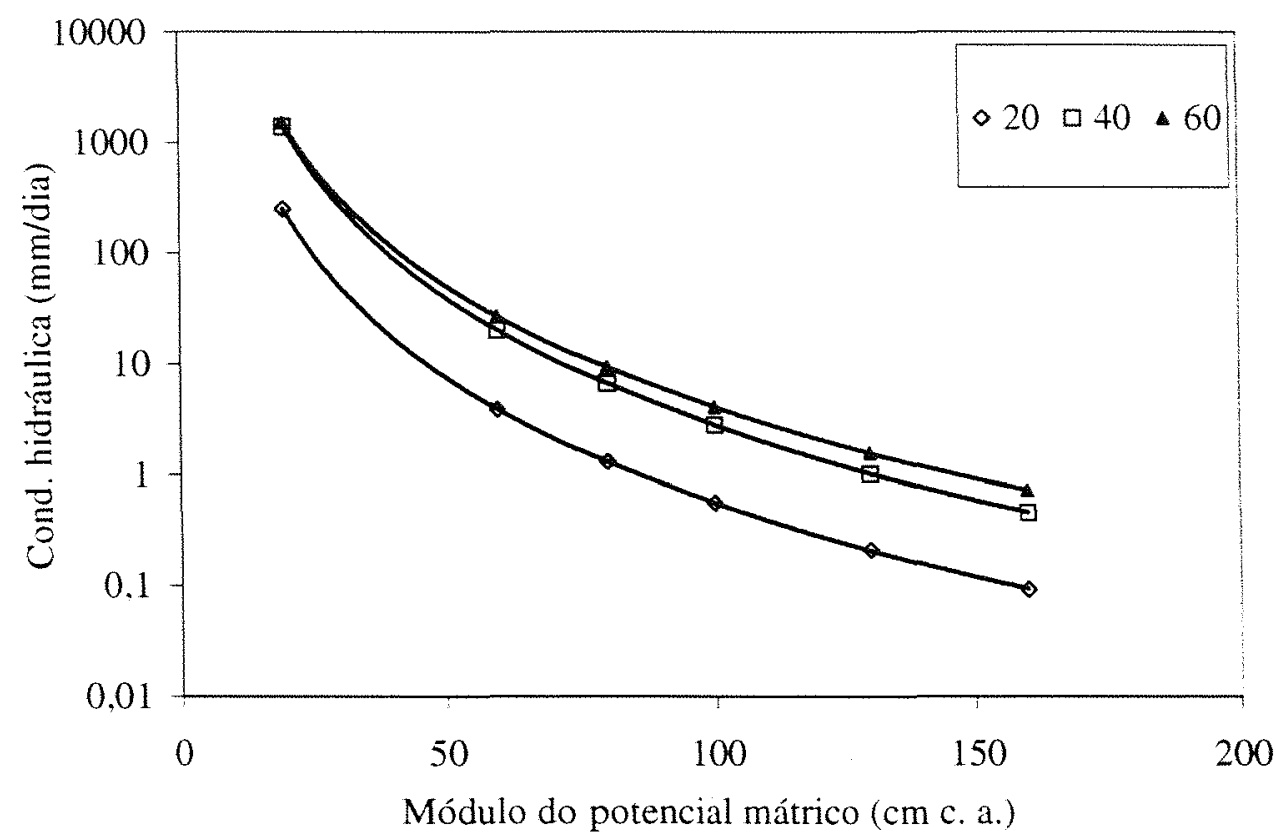

Figura 11. Curvas da condutividade hidráulica do solo, em função do módulo do potencial mátrico (cmc.a.), para as diferentes camadas de solo (Medeiros, 1998).

\subsection{Distribuição espacial do sistema radicular do limão 'Cravo' em lima ácida} 'Tahiti', por meio de imagens digitalizadas.

Para esta análise, utilizaram-se apenas os resultados de comprimento de raízes e não os de área, pois, de acordo com Weller (1971), a representação da quantidade de raízes, através do comprimento. expressa uma idéia melhor. De fato, o comprimento, ao contrário da massa, expressa melhor a ocorrência das raízes finas, mais importantes na absorção de água e de nutrientes. Os resultados, obtidos nas imagens digitais, são mostrados na forma de gráficos de contorno, onde o tronco da árvore está localizado sempre na coordenada $(0,0)$. Os resultados, obtidos com as análises do comprimento de raiz ( $\mathrm{cm}$ de raiz $/ 625 \mathrm{~cm}^{3}$ de solo) nas duas plantas amostradas, são apresentados nas Figuras 12 e 13.

Para os cálculos da estimativa da distribuição espacial do sistema radicular, utilizou-se um esquema de anéis concêntricos, mostrado na Figura 6. Primeiro. calculouse o volume de solo referente a cada quadrícula filmada no quadro instalado na trincheira; 
em seguida, extrapolaram-se os resultados para o volume do anel, como apresentado nas Figuras 14 e 15, em comprimento de raiz (cm), por volume de solo do anel correspondente.

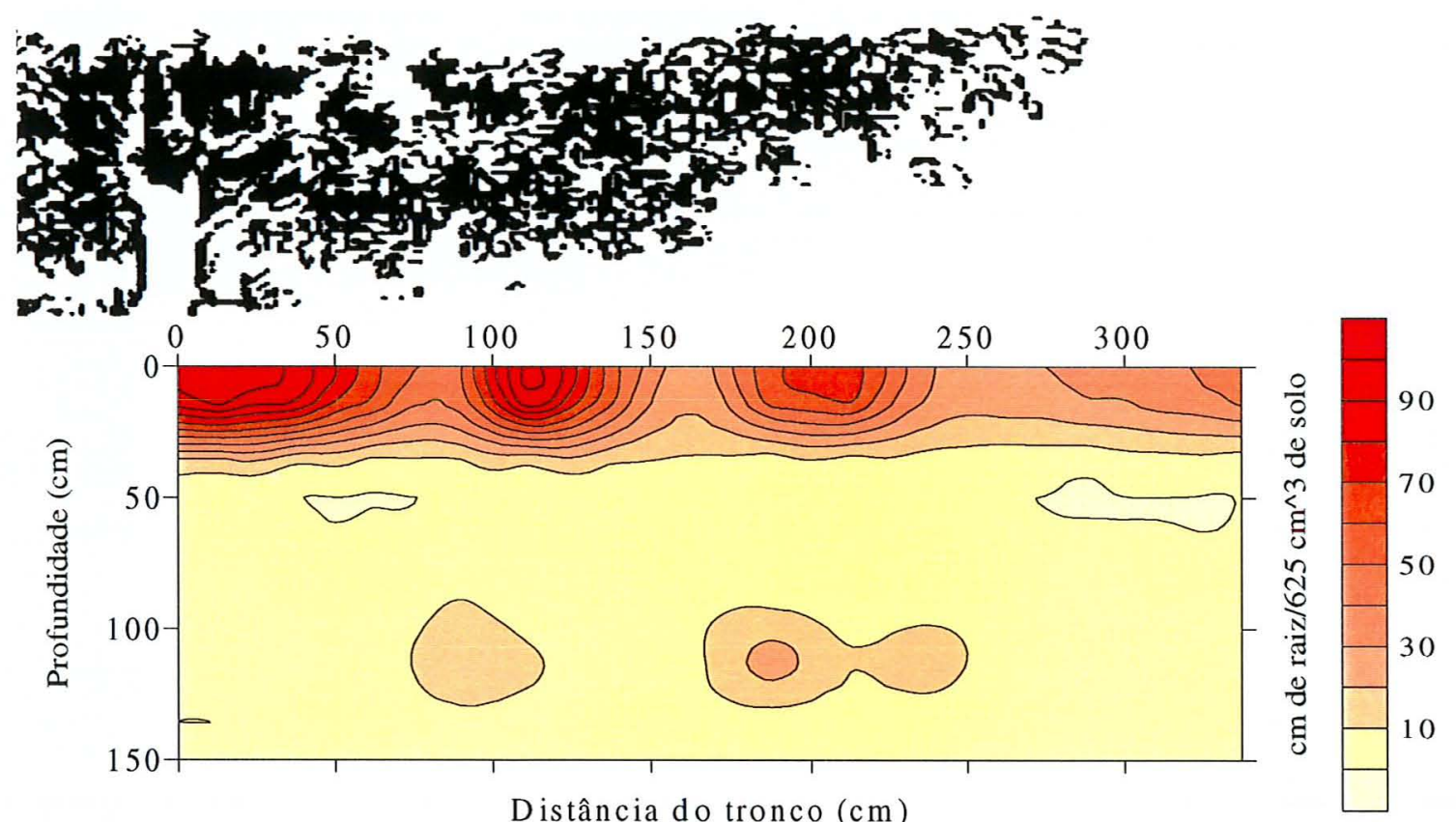

Figura 12. Isolinhas de comprimento de raiz em $\mathrm{cm}$ de raiz / $625 \mathrm{~cm}^{3}$ de solo, na planta 1 .

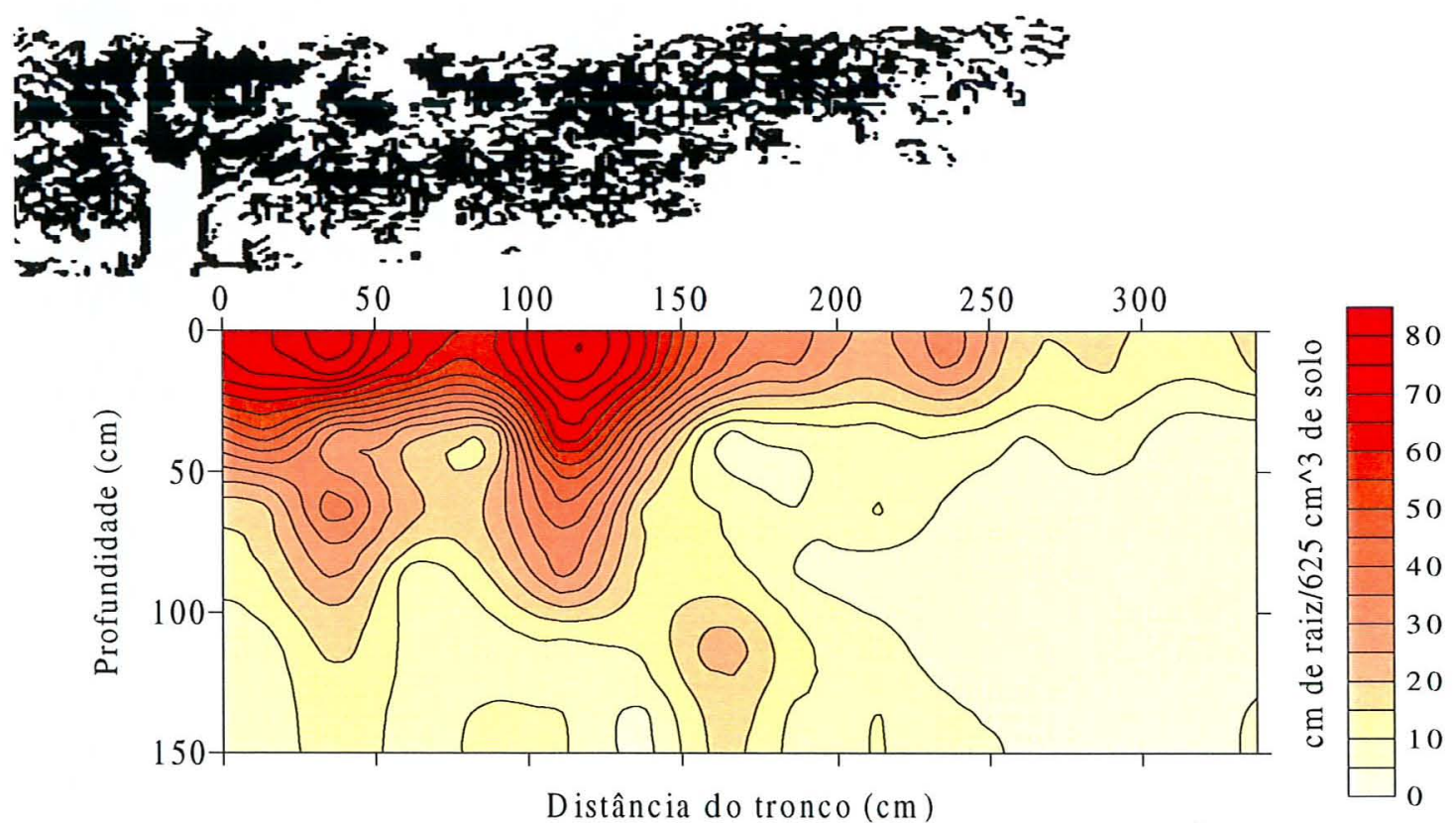

Figura 13. Isolinhas de comprimento de raiz em $\mathrm{cm}$ de raiz / $625 \mathrm{~cm}^{3}$ de solo, na planta 2 . 


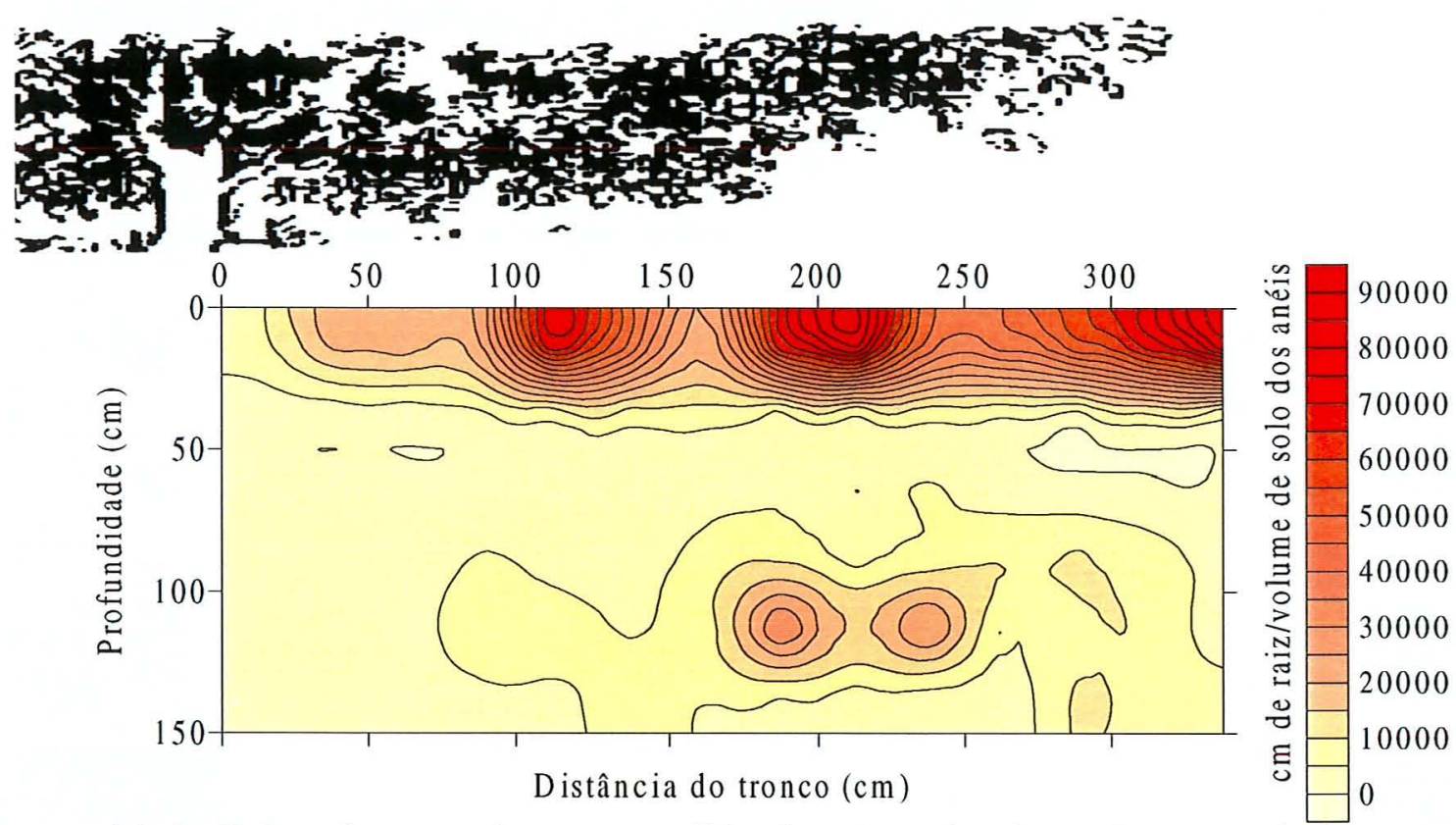

Figura 14. Isolinhas do comprimento medido de raízes da planta 1, extrapoladas para todo o volume de solo da planta ( $\mathrm{cm}$ de raiz/ volume de solo do anel correspondente).

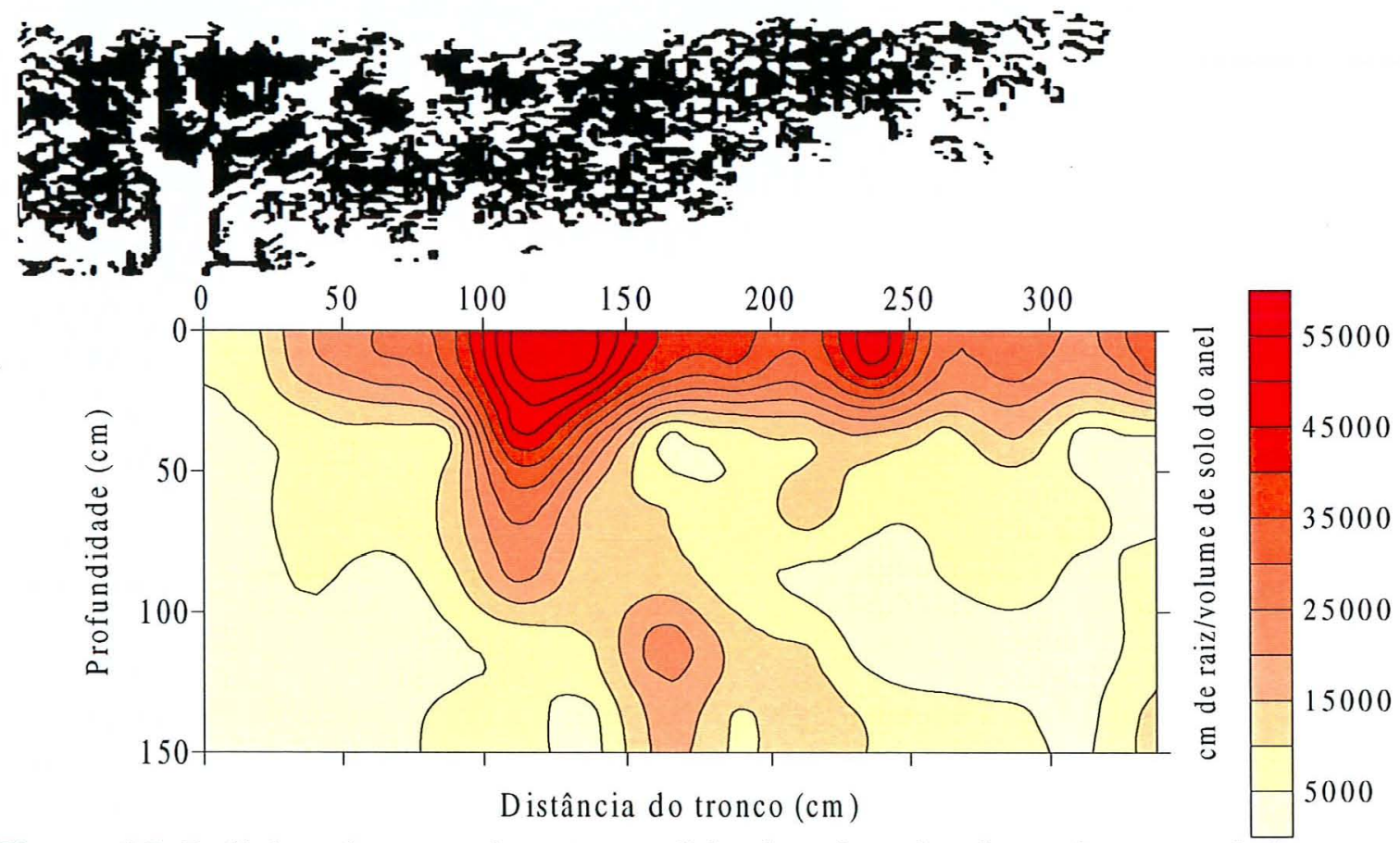

Figura 15. Isolinhas do comprimento medido de raízes da planta 2, extrapoladas para todo o volume de solo da planta ( $\mathrm{cm}$ de raiz/ volume de solo do anel correspondente). 
Analisando as Figuras 12 e 13, verificou-se uma certa variação na distribuição das raízes entre as plantas em estudo. Na Figura 12 (planta 1), as raízes concentraram-se em até $50 \mathrm{~cm}$ de profundidade, o que pode ter sido provocado por uma camada mais compactada de solo, ou mesmo por uma camada de impedimento químico, que não deixou que as raízes se aprofundassem. Analisando os resultados de densidade do solo, verificou-se que o maior valor se encontra na camada de $25-50 \mathrm{~cm}\left(14,6 \mathrm{~kg} / \mathrm{m}^{3}\right)$; porém, segundo Gregory (1988), a densidade limite, que permite o crescimento radicular para as culturas em geral, para solos argilo-siltosos, é de $15,5 \mathrm{~kg} / \mathrm{m}^{3}$. Os resultados aqui apresentados situaram-se abaixo desse valor. Castle (1980), em experimentos de densidade de plantio, observou, com o método do trado, a distribuição do sistema radicular da laranja 'Pineapple' enxertada sobre limão 'Rugoso', em três espaçamentos de plantio em solo arenoso, que as raízes se apresentavam em maior concentração e se aprofundavam mais nos plantios mais adensados, compensando, assim, a menor área de solo disponível. Já na Figura 13 (planta 2), mostram-se raízes chegando a $75 \mathrm{~cm}$ de profundidade.

Pôde-se observar que ocorre uma maior concentração de raízes próximo ao tronco da árvore. Porém, ao se extrapolarem os resultados obtidos para todo o volume de solo explorado pelas raízes da planta (Figura 14 e 15), verificou-se que, de 100 a $250 \mathrm{~cm}$ de distância do tronco, acontece a maior concentração de raízes, como pode ser observado nas Figuras 14 e 15.

Quanto às percentagens $(\%)$ de área e comprimento de raízes medidas e estimadas, elas se encontram apresentadas em relação à distância do tronco, na Figura 16, e em relação às profundidades, na Figura 17.

Para a construção do perfil de distribuição percentual das raízes, utilizou-se a média das duas plantas amostradas; dessa forma, construíram-se o perfil de distribuição percentual das raízes, sem a extrapolação (Figura 18), e o perfil de distribuição percentual das raízes, estimadas no volume de solo da planta. com a extrapolação para todo o volume de solo (Figura 19).

Analisando os resultados, observou-se que aproximadamente $75 \%$ do comprimento medido, encontram-se em profundidade de até $75 \mathrm{~cm}$. 


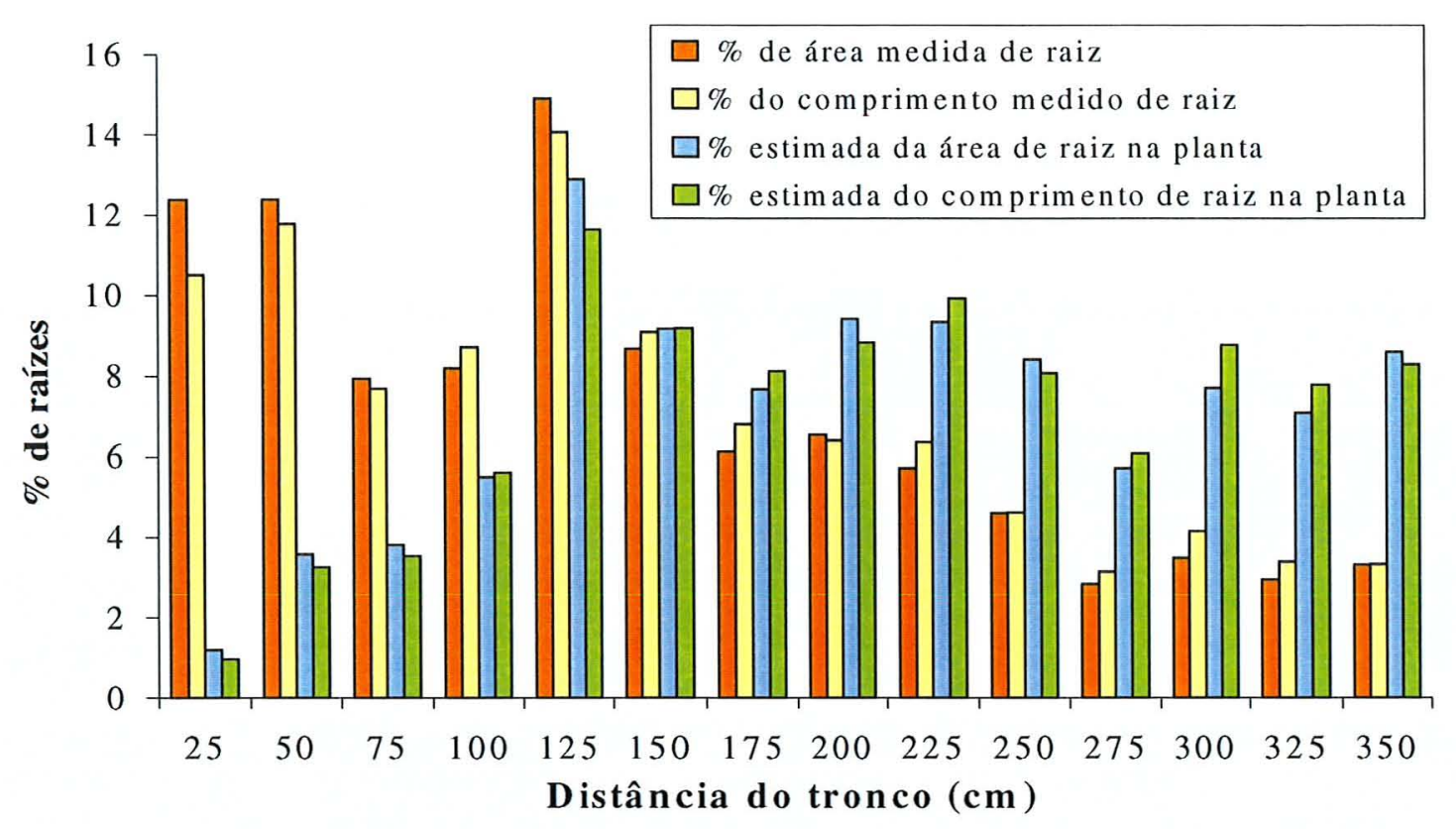

Figura 16. Distribuição percentual do sistema radicular, em função da distância do tronco.

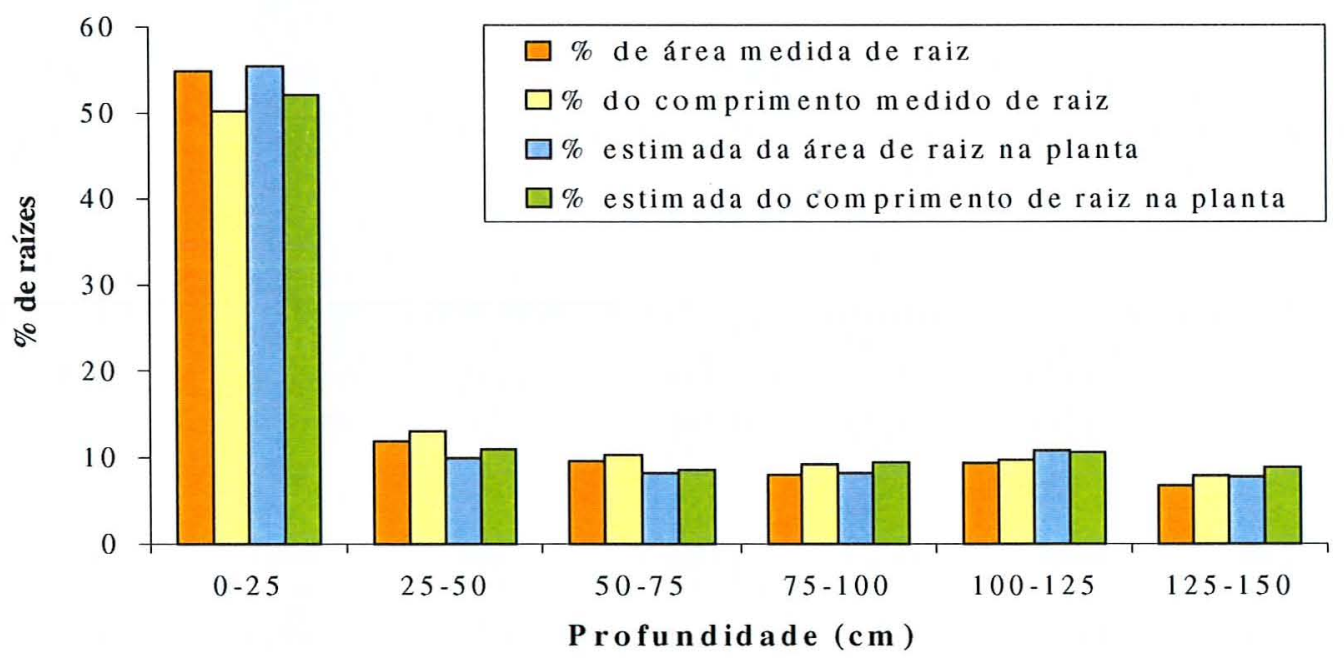

Figura 17. Distribuição percentual do sistema radicular, em função das camadas de solo em análise. 


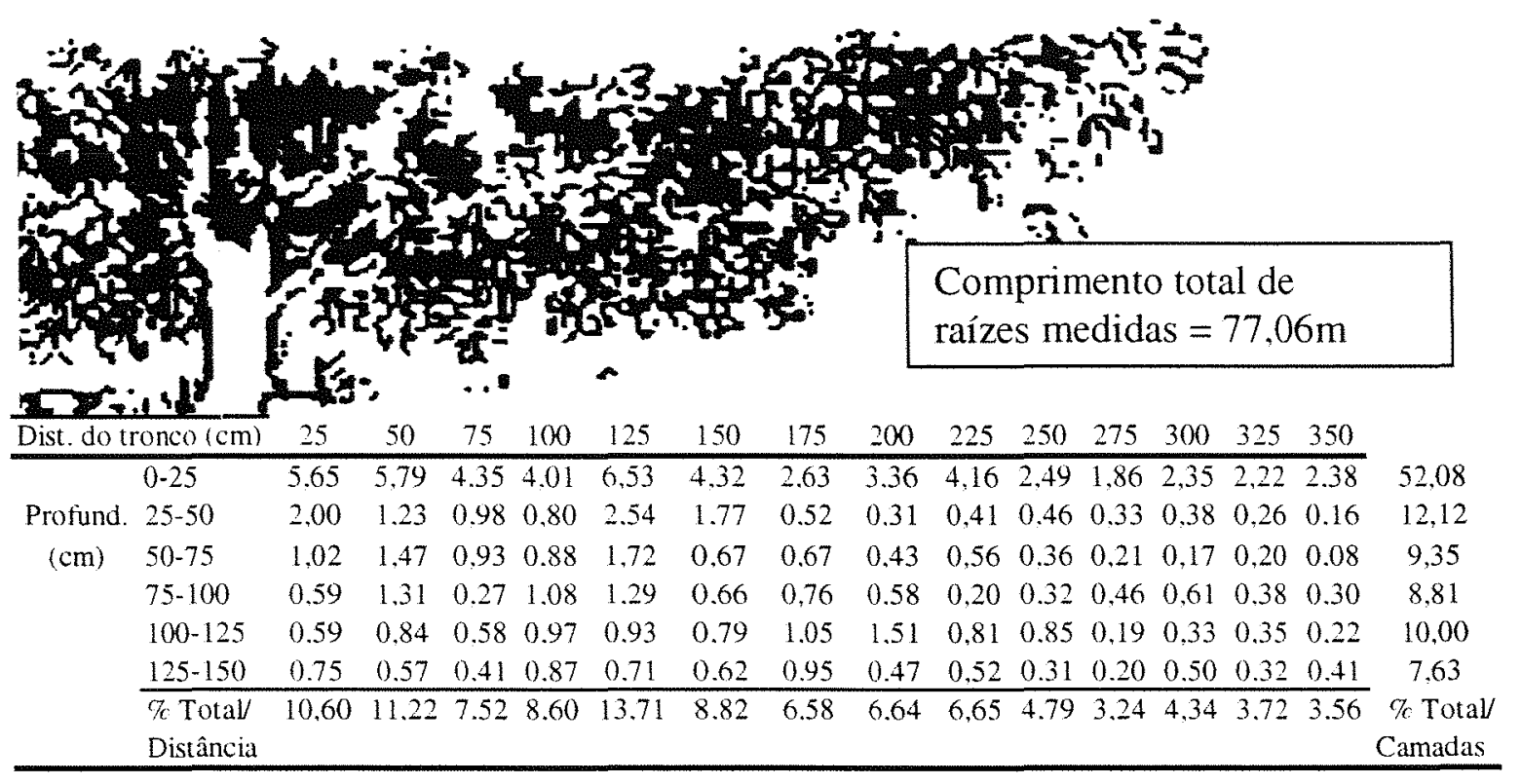

Figura 18. Perfil de distribuição percentual das raízes medidas no perfil de solo, valor médio das duas plantas amostradas, sem a extrapolação.

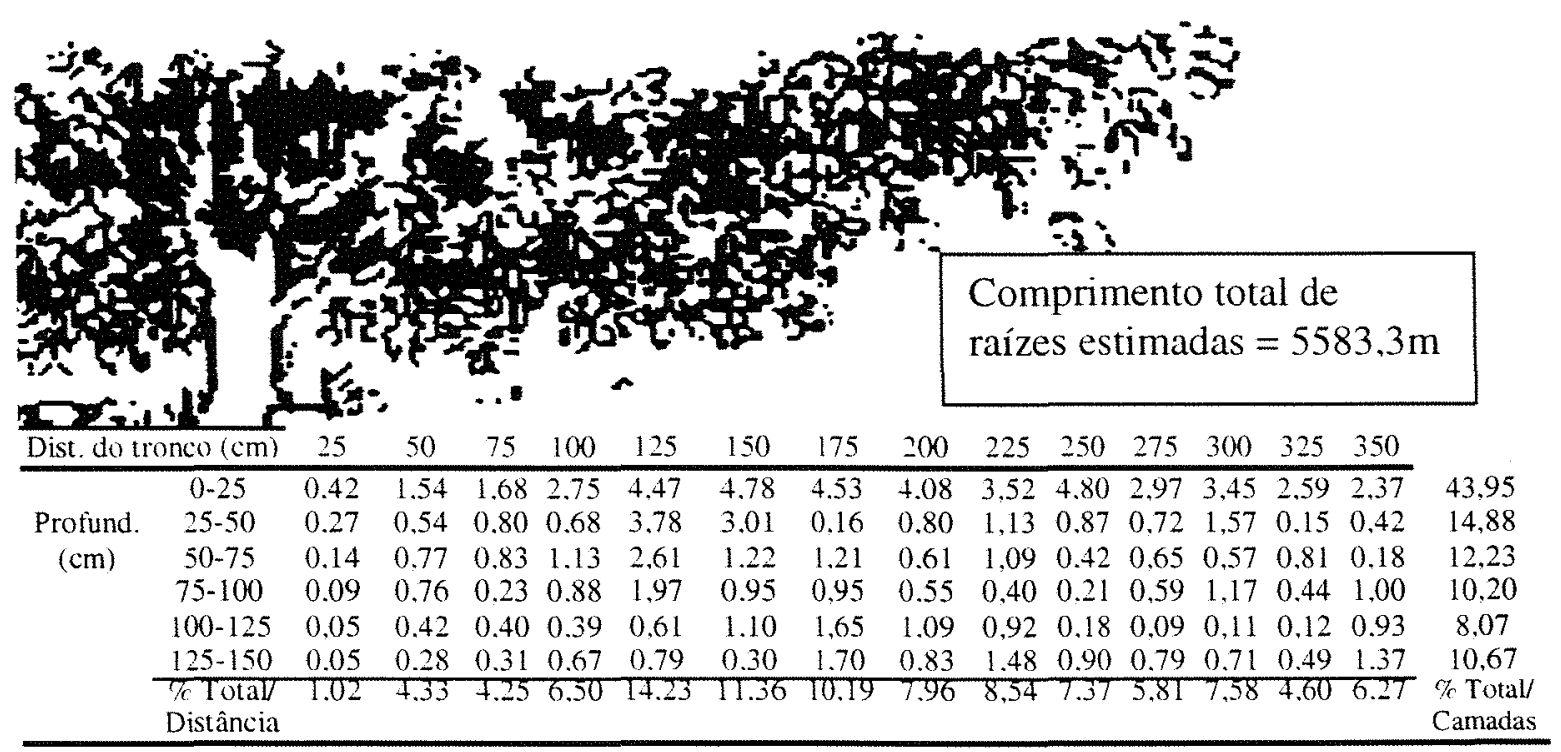

Figura 19. Perfil de distribuição percentual das raízes estimadas no volume de solo da planta, valor médio das duas plantas amostradas, com a extrapolação para todo o volume de solo. 
4.3 Atividade espacial do sistema radicular do limão 'Cravo' em lima ácida 'Tahiti', por meio da variação do conteúdo de água no solo.

A análise da atividade espacial do sistema radicular do porta-enxerto limão 'Cravo', por meio da variação do conteúdo de água no solo, foi realizada para três períodos diferentes, sendo o primeiro de 26/02 a 08/03, o segundo de 13/03 a 21/03 e o terceiro de 17/04 a 02/05. Os resultados da evapotranspiração e do consumo de solução dos três períodos analisados estão na Tabela 5 , encontrando-se os resultados originais de todos os ciclos no Apêndice 3 .

A Tabela 6 mostra a planilha de cálculo no primeiro ciclo e da planta 1; calculou-se a evapotranspiração da cultura pela variação do armazenamento de água no solo (eq. 6). Para o cálculo do consumo de água pela planta, multiplicou-se a evapotranspiração calculada pela área que cada bateria de tensiômetros representava. A estimativa do perfil percentual da atividade radicular foi calculada através da razão da evapotranspiração da subárea pelo somatório de todas as evapotranspirações das camadas consideradas e também pela razão do consumo de água na subárea pelo somatório de todo o consumo da planta. A área total, representada pelas 13 baterias de tensiômetros instaladas em cada planta, foi de 50\% da projeção da copa. Assim, os resultados de consumo de solução pela planta devem ser duplicados, pois $100 \%$ do sistema radicular da planta estava com a mesma disponibilidade hídrica no solo.

Tabela 5. Resultados da Evapotranspiração da cultura ( $\mathrm{mm} / \mathrm{dia})$, do consumo de solução ( $L$ dia) e coeficientes de cultura determinados para os períodos em análise.

\begin{tabular}{|c|c|c|c|c|c|c|c|c|c|}
\hline & \multicolumn{3}{|c|}{$\mathrm{ET}(\mathrm{mm} / \mathrm{dia})$} & \multicolumn{3}{|c|}{ Consumo (L/dia) } & \multicolumn{3}{|c|}{ Coef. Cultura (Kc) } \\
\hline & $1^{\circ}$ ciclo & $2^{\circ}$ ciclo & $3^{\circ}$ ciclo & $1^{\circ}$ ciclo & $2^{\circ}$ ciclo & $3^{\circ}$ ciclo & $1^{\circ}$ ciclo & $2^{\circ}$ ciclo & $3^{\circ}$ ciclo \\
\hline Planta $n^{\circ} 1$ & 1,86 & 2,44 & 1,88 & 43,00 & 58,21 & 44,93 & 0.58 & 0,60 & 0,60 \\
\hline Planta $n^{\circ} 2$ & 1.78 & 2.49 & 1.48 & 43.29 & 60.54 & 35.91 & 0.56 & 0.61 & 0.47 \\
\hline
\end{tabular}

Para a construção do perfil de distribuição percentual da atividade radicular, utilizaram-se os resultados da evapotranspiração da cultura e do consumo de solução do solo. Os perfis estão mostrados nas Figuras 20, 21.22 e 23. 


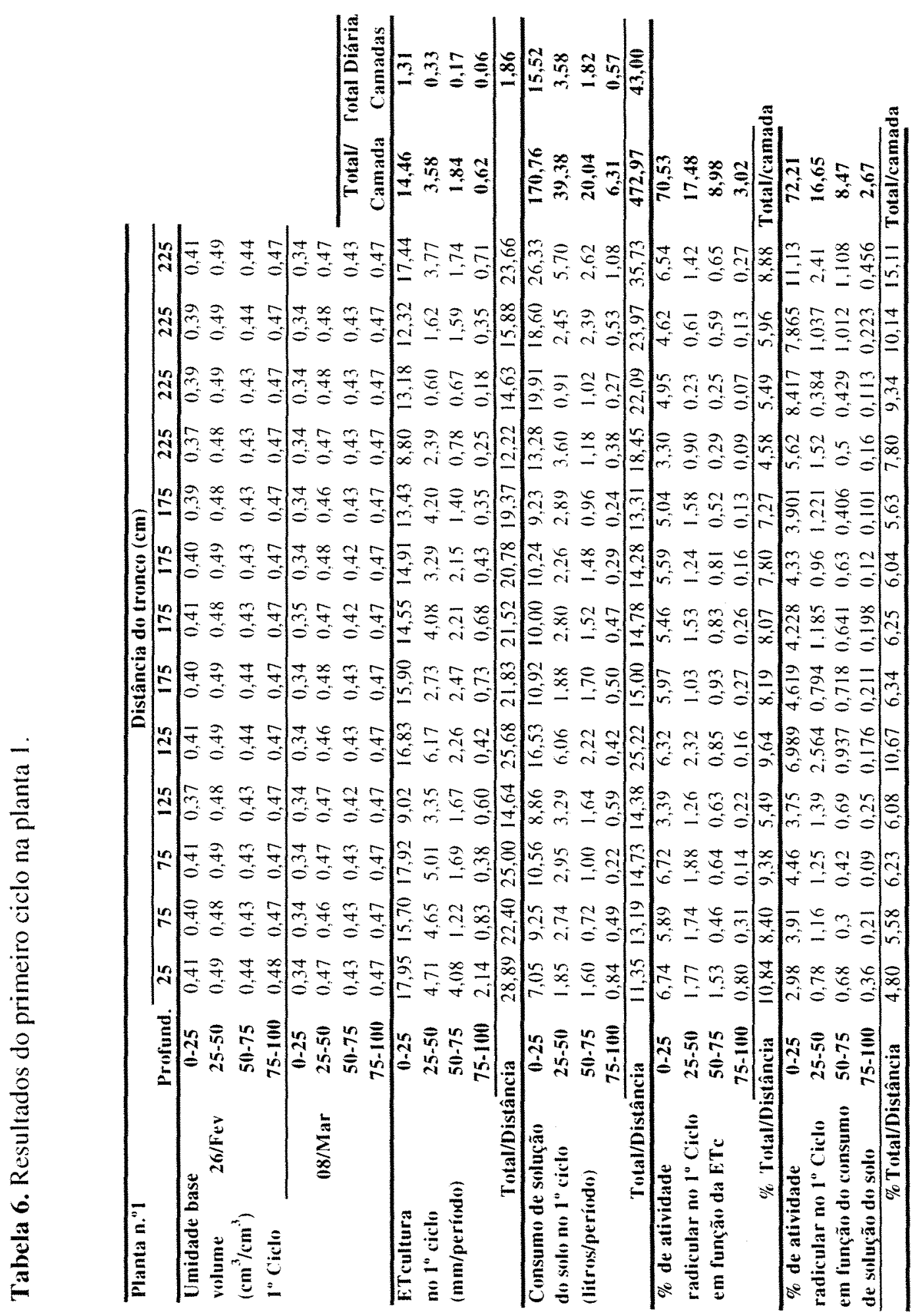




\begin{tabular}{|c|c|c|c|c|c|c|c|c|c|c|c|c|c|c|c|}
\hline & & & & & & & stância & do tror & $\mathrm{nco}(\mathrm{cr}$ & & & & & & FTotal / \\
\hline & Profund. & 25 & 75 & 75 & 125 & 125 & 175 & 175 & 175 & 175 & 225 & 225 & 225 & 2250 & Camadas \\
\hline \multirow{4}{*}{$26 / 02$ a $8 / 03$} & $0-25$ & 6,74 & 5,89 & 6.72 & 3,39 & 6.32 & 5.97 & 5,46 & 5.59 & 5.04 & 3.30 & 4,95 & 4,62 & 6.54 & 70.53 \\
\hline & $25-50$ & 1,77 & 1,74 & 1.88 & 1,26 & 2.32 & 1,03 & 1.53 & 1,24 & 1,58 & 0,90 & 0,23 & 0,61 & 1,42 & 17,48 \\
\hline & $50-75$ & 1.53 & 0,46 & 0,64 & 0,63 & 0.85 & 0,93 & 0,83 & 0,81 & 0,52 & 0,29 & 0,25 & 0.59 & 0,65 & 8.98 \\
\hline & $75-100$ & 0.80 & 0,31 & 0.14 & 0.22 & 0.16 & 0.27 & 0.26 & 0.16 & 0.13 & 0.09 & 0.07 & 0.13 & 0.27 & 3.02 \\
\hline \multicolumn{2}{|c|}{ \% Total/Distância } & 10.84 & 8.40 & 9.38 & 5.49 & 9.64 & 8.19 & 8.07 & 7.80 & 7.27 & 4.58 & 5.49 & 5.96 & 8.88 & \\
\hline \multirow{4}{*}{$\begin{array}{l}2^{\circ} \mathrm{Ciclo} \\
13 / 03 \text { a } 21 / 03\end{array}$} & $0-25$ & 5.49 & 4,90 & 5,32 & 5,36 & 5.47 & 5,25 & 5,38 & 5,44 & 5,10 & 5,10 & 5,52 & 5.70 & 5.48 & $\overline{69,49}$ \\
\hline & $25-50$ & 2,08 & 2,12 & 1.95 & 1,10 & 1,92 & 0,94 & 1,79 & 0,79 & 1,32 & 0.94 & 0,66 & 0,65 & 1,27 & 17,52 \\
\hline & $50-75$ & 1.51 & 0.15 & 0.89 & 1,05 & 0.80 & 0.88 & 1,23 & 1.07 & 0.56 & 0,10 & 0,42 & 0,75 & 0,05 & 9,47 \\
\hline & $75-100$ & 0.68 & 0.41 & 0.13 & 0.31 & 0.19 & 0.34 & 0.35 & 0.11 & 0.17 & 0.07 & 0.25 & 0.18 & 0.34 & 3.52 \\
\hline \multicolumn{2}{|c|}{ ?c Total/Distância } & 9.76 & 7.58 & 8.29 & 7.82 & 8.38 & 7.41 & 8.74 & 7.40 & 7.15 & 6.21 & 6.85 & 7.27 & 7.13 & \\
\hline \multirow{4}{*}{$\begin{array}{l}3^{\circ} \text { Ciclo } \\
17 / 04 \text { a 02/05 }\end{array}$} & $0-25$ & 5.23 & 4,93 & 5.09 & 4,31 & 5.93 & 5,28 & 4.97 & 5,31 & 4,96 & 4.44 & 4.66 & 4.67 & 4,86 & 64,65 \\
\hline & $25-50$ & 1.99 & 1,72 & 0.21 & 1,23 & 2.47 & 1.60 & 2.23 & 1,57 & 1,35 & 0,87 & 1,36 & 1,39 & 1.77 & 19,75 \\
\hline & $50-75$ & 1,60 & 0,47 & 1.25 & 1,70 & 0.84 & 1.37 & 0,62 & 1.21 & 0,62 & 0.02 & 0,41 & 0,20 & 1.96 & 12,28 \\
\hline & $75-100$ & 0.92 & 0.09 & 0.10 & 0.01 & 0.06 & 0.33 & 0.45 & 0.21 & 0.10 & 0.01 & 0.39 & 0.17 & 0.48 & 3.32 \\
\hline \multicolumn{2}{|c|}{ \% Total/Distância } & 9.75 & 7.21 & 6.64 & 7.25 & 9.30 & 8.58 & 8.27 & 8.30 & 7.03 & 5.34 & 6.83 & 6.42 & 9.07 & \\
\hline
\end{tabular}

Figura 20. Perfil de distribuição percentual da atividade radicular, em função da ETc da planta 1.

\begin{tabular}{|c|c|c|c|c|c|c|c|c|c|c|c|c|c|c|c|}
\hline & & & & & & Dist & ância & do tro & onco id & & & & & & \%Tota \\
\hline & Profund. & 25 & 75 & 75 & 125 & 125 & 175 & 175 & 175 & 175 & 225 & 225 & 225 & 225 & Camadas \\
\hline & $0-25$ & 6.95 & 6.50 & 4.47 & 2.37 & 5.86 & 6.27 & 6.31 & 5.01 & 5.83 & 5.32 & 5.62 & 6.59 & 6.30 & 73.40 \\
\hline Ciclo & $25-50$ & 2.32 & 2.20 & 1.86 & 1.43 & 1.23 & 0.65 & 0.79 & 1.03 & 1.17 & 3.17 & 1.14 & 0.98 & 0.38 & 18.34 \\
\hline$/ 02$ a $8 / 03$ & $50-75$ & 1.09 & 0.35 & 0.32 & 0.39 & 0.34 & 0.23 & 0.22 & 0.42 & 0.71 & 0.26 & 0.67 & 0.61 & 0.37 & 5.97 \\
\hline & $75-100$ & 0.54 & 0.39 & 0.18 & 0.11 & 0.06 & 0.05 & 0.18 & 0.14 & 0.07 & 0.16 & 0.19 & 0.10 & 0.11 & 2.29 \\
\hline \% Total/Dis & ância & 10.90 & 9.43 & 6.83 & 4.30 & 7.49 & 7.20 & 7.50 & 6.60 & 7.79 & 8.91 & 7.61 & 8.27 & 7.16 & \\
\hline & $0-25$ & 5.32 & 4.76 & 4.57 & 5.09 & 5.09 & 5.40 & 5.63 & 5.37 & 4.84 & 4.97 & 4.95 & 5.63 & 5.67 & 67.28 \\
\hline Ciclo & $25-50$ & 2.59 & 2.12 & 2.39 & 2.23 & 1.88 & 1.40 & 1.54 & 1.02 & 1.90 & 2.29 & 0.83 & 1.46 & 0.74 & 22.39 \\
\hline $3 / 03$ a $21 / 03$ & $50-75$ & 1.22 & 0.47 & 0.78 & 0.67 & 0.63 & 0.53 & 0.45 & 0.19 & 0.27 & 0.28 & 0.65 & 0.72 & 0.50 & 7.35 \\
\hline & $75-100$ & 0.59 & 0.36 & 0.13 & 0.28 & 0.05 & 0.05 & 0.21 & 0.25 & 0.22 & 0.42 & 0.15 & 0.01 & 0.25 & 2.98 \\
\hline \% Total/Dis & ância & 9.73 & 7.71 & 7.88 & 8.28 & 7.64 & 7.37 & 7.83 & 6.82 & 7.24 & 7.96 & 6.59 & 7.81 & 7.16 & \\
\hline & $0-25$ & 6.20 & 6.07 & 2.87 & 5.74 & 5.71 & 5.86 & 5.53 & 6.49 & 6.21 & 5.75 & 5.49 & 4.97 & 5.99 & 72.87 \\
\hline $3^{\circ}$ Ciclo & $25-50$ & 2.93 & 2.95 & 0.30 & 1.42 & 0.43 & 0.13 & 0.07 & 2.40 & 1.17 & 2.43 & 2.17 & 0.05 & 1.20 & 17.64 \\
\hline $17 / 04$ a $02 / 05$ & $50-75$ & 2.02 & 1.22 & 0.47 & 0.98 & 0.06 & 0.10 & 0.04 & 0.03 & 0.14 & 0.01 & 0.20 & 0.49 & 0.54 & 6.31 \\
\hline & $75-100$ & 0.88 & 0.10 & 0.12 & 0.27 & 0.24 & 0.16 & 0.25 & 0.07 & 0.30 & 0.22 & 0.26 & 0.06 & 0.24 & 3.17 \\
\hline$\% \mathrm{~T}$ & tância & 12.03 & 10.34 & 3.75 & 8.41 & 6.44 & 6.25 & 5.89 & 9.00 & 7.82 & 8.41 & 8.11 & 5.57 & 7.98 & \\
\hline
\end{tabular}

Figura 21. Perfil de distribuição percentual da atividade radicular, em função da ETc da planta 2. 


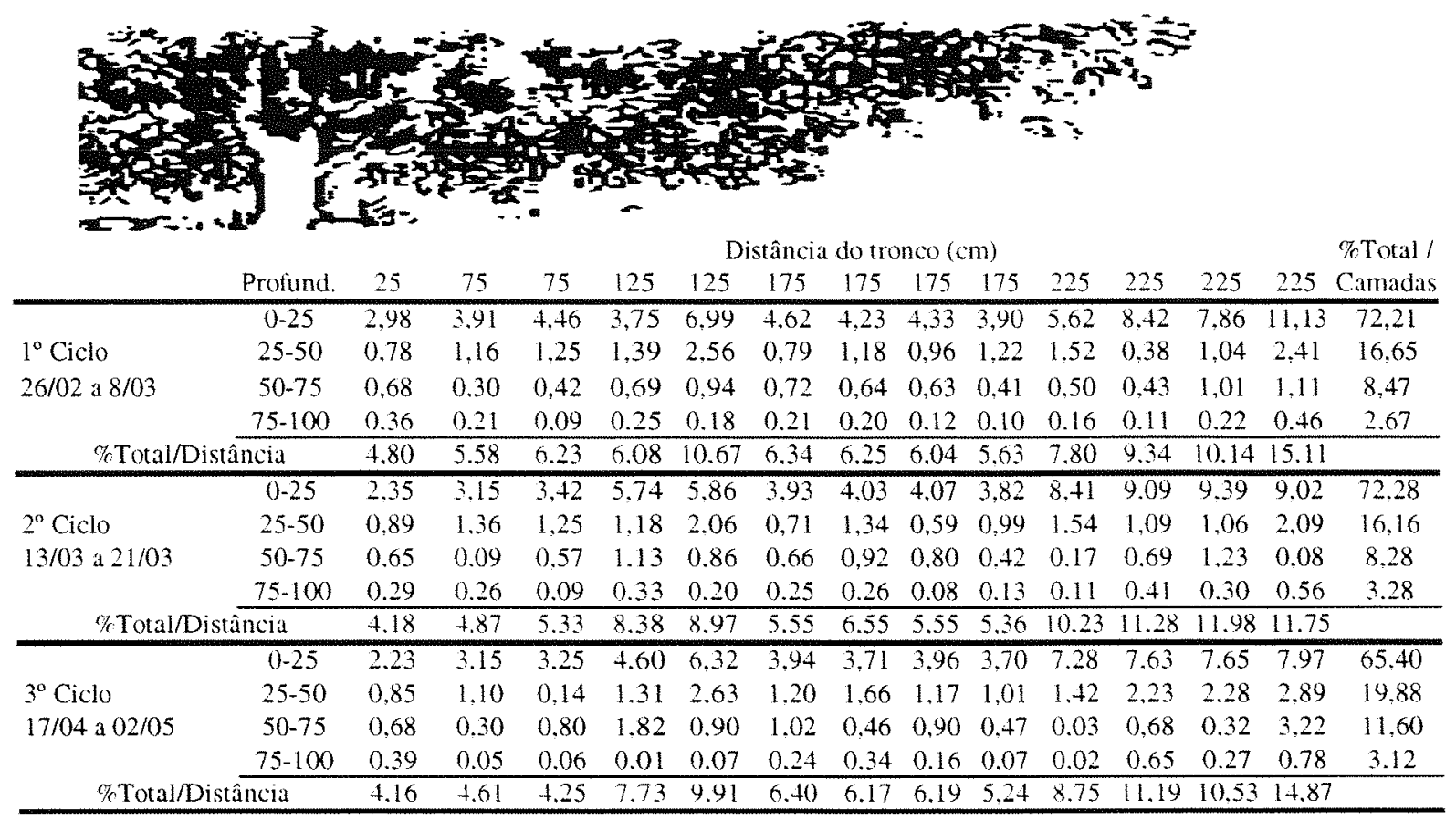

Figura 22. Perfil de distribuição percentual da atividade radicular, em função do consumo de solução do solo, da planta 1 .

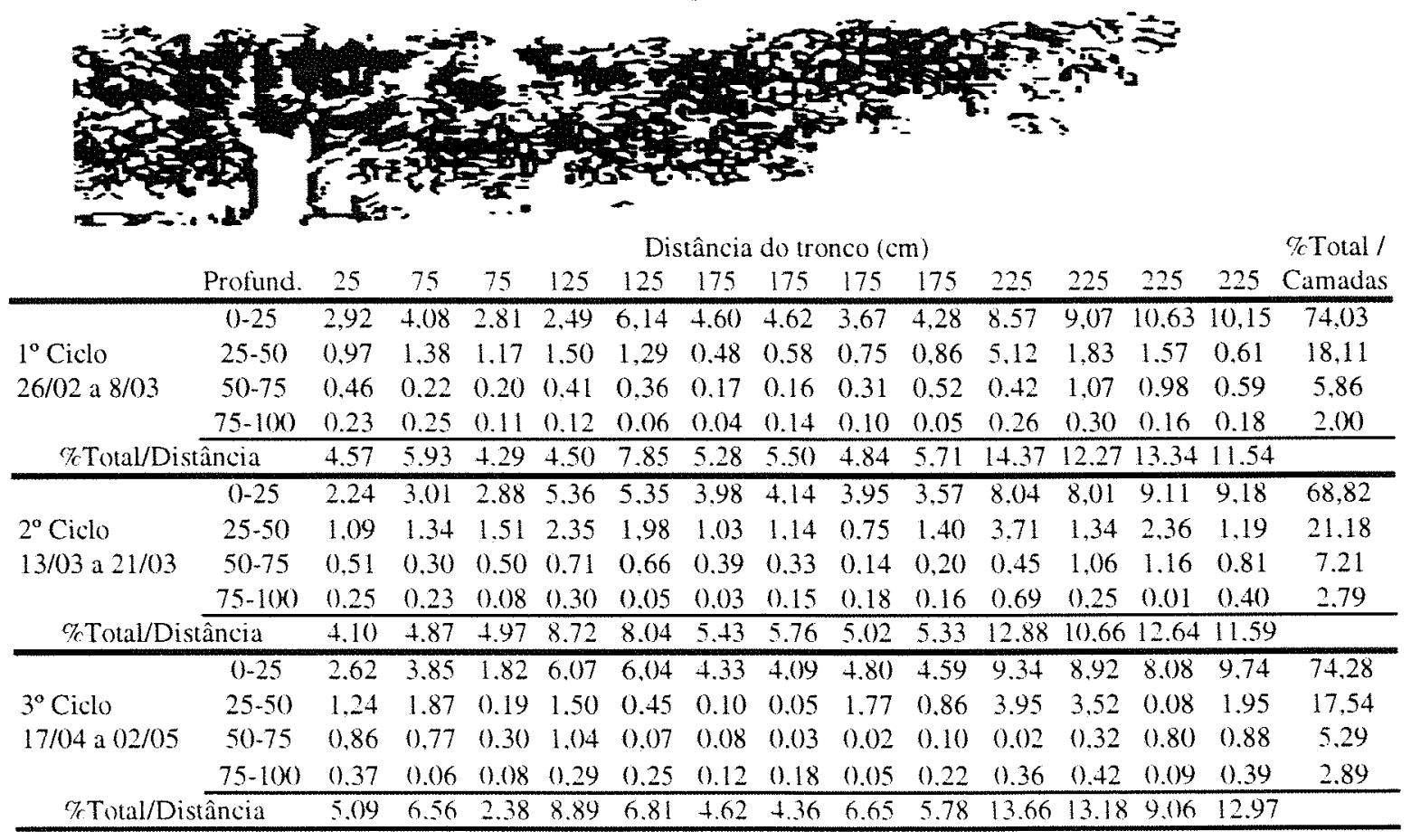

Figura 23. Perfil de distribuição percentual da atividade radicular. em função do consumo de solução do solo, da planta 2. 
Arruda (1989) define a profundidade efetiva (Pe) das raízes como a profundidade do perfil do solo onde se encontram, pelo menos, $80 \%$ do total do sistema radicular. Já o conceito da distribuição das raízes na horizontal, ou seja, a determinação da sua distância efetiva (De), definida como a distância a partir do tronco da planta onde se encontram, pelo menos, $80 \%$ do total de raízes, é de uso recente. Esse conceito, de pouco valor antes da advento da irrigação localizada, é muito importante, pois indica a área de onde se deverão retirar amostras de solo para o controle da umidade, ou a melhor área para a colocação de instrumentos, como o tensiômetro, visando ao manejo da irrigação. Ainda. em sistemas de irrigação localizada, permite fixar a distância adequada, a partir do tronco, para a aplicação da água. Gomes (1996) foi, praticamente, o primeiro autor a usar o termo distância efetiva: os dados de sua pesquisa para citros irrigados ficaram entre 1,56 e $1,63 \mathrm{~m}$.

Analisando os resultados obtidos pelo método da trincheira. observa-se que, aproximadamente, entre 44 e $52 \%$ do comprimento total de raizes do porta-enxerto limão 'Cravo', em condição de sequeiro, encontram-se na camada de 0 a $25 \mathrm{~cm}$ da superfície do solo, e que, aproximadamente, entre 21 e $27 \%$ do comprimento total de raízes do portaenxerto limão 'Cravo', em condição de sequeiro, encontram-se na camada de 25 a $75 \mathrm{~cm}$ da superfície do solo. Esses resultados confirmam os obtidos por Neves (1998), que estudou, pelo método da trincheira, o efeito do manejo do solo no sistema radicular de tangerina 'Poncã', enxertada sobre limão 'Cravo', e em atributos físicos de um latossolo roxo. Com base nos resultados obtidos, determinou-se a profundidade efetiva (Pe) na linha de plantio, cujo valor foi de 0,60 metro. Tal resultado está de acordo com os obtidos por Rodriguez et al.(1978), por Montenegro (1960), por Moreira (1983), por Gomes (1996) e por Oliveira et al. (1998). Com a distribuição das raízes na horizontal. verificouse que a distância efetiva (De) é de $2,0 \mathrm{~m}$ de distância do tronco; porém, como as copas apresentam tamanhos diferentes, pode-se dizer que a De está entre 50 e $75 \%$ do raio da projeção da copa. O resultado confirma os obtidos por Gomes (1996) e por Oliveira et al. (1998).

Oliveira et al. (1998) mostram que as raízes cítricas se distribuem, praticamente, na mesma proporção em todas as direções: com isso. pode-se concluir que o método da 
trincheira é adequado para a realização do estudo do sistema radicular das plantas cítricas, sem a formação de "ranking".

Os maiores problemas encontrados nas técnicas de estudo da atividade e da distribuição do sistema radicular são o tempo de amostragem, a destruição do sistema exigida pelos métodos, assim como a acentuada variabilidade espacial encontrada. Tais inconvenientes têm levado ao desenvolvimento de métodos indiretos, como o estudo da variação temporal do conteúdo de água do solo.

O método baseia-se na hipótese de que a taxa de decréscimo de água no solo se correlaciona com a quantidade de raízes; dessa forma, obtiveram-se os resultados da atividade de absorção de água do porta-enxerto limão 'Cravo', em condição de sequeiro. A camada de $0-25 \mathrm{~cm}$ de profundidade foi responsável pela taxa de 68 a $74 \%$ do volume de solução absorvida, valor superior, em aproximadamente $24 \%$, ao comprimento total de raízes nessa camada ( 44 a 52\%), evidenciando que as raízes mais rasas apresentam maior capacidade de absorção e de condutividade hidráulica.

Os resultados confirmam os valores de $\mathrm{Pe}$ e De obtidos pelo método da trincheira e também o citado por Pearson (1974) e Bohm (1979), que avaliam que a principal vantagem desse método, além de não ser destrutivo, é que o resultado expressa diretamente a habilidade da planta em retirar água das diferentes camadas do solo, permitindo inferir sobre a atividade do sistema radicular no perfil do solo. 
4.4 Análise da absorção de água pela planta em diferentes áreas de umedecimento.

$\mathrm{Na}$ planta 1 deste experimento, foram instalados no dia 26 de agosto, 64 supertensiômetros de carga constante e, na planta 2 , apenas 32, no dia 22 de agosto. Com o monitoramento do potencial mátrico no bulbo molhado pela cápsula porosa, verificouse que aquele se mantém a $10 \mathrm{kPa}$ até $15 \mathrm{~cm}$ de distância da cápsula. Analisando o consumo de água diário, em cada supertensiômetro instalado, verificou-se que os volumes fornecidos por cada cápsula foi semelhante ao da cápsula com monitoramento, podendo-se concluir que os bulbos molhados não foram diferentes uns dos outros. Com isso, calculou-se a área molhada por cada supertensiômetro de carga constante instalado e, conseqüentemente, a área molhada em cada uma das plantas em estudo e seus respectivos valores de $\mathrm{PW}$ e $\mathrm{P}$, no periodo analisado (Tabela 7). Um dos fatores que influenciou no tamanho do bulbo molhado foi a condutividade hidráulica do solo, principalmente na faixa de potencial mátrico entre 10 a $20 \mathrm{kPa}$, cujo a condutividade hidráulica varia de 1 a $0,1 \mathrm{~mm} /$ dia, respectivamente.

Tabela 7. Valores de PW e P em porcentagem e a área molhada pelo sistema proposto.

\begin{tabular}{lccc}
\hline & PW $(\%)$ & P $(\%)$ & Área Molhada $\left(\mathrm{m}^{2}\right)$ \\
\hline Planta 1 & 10.80 & 24.40 & 6.08 \\
Planta 2 & 5.38 & 12.25 & 3.02 \\
\hline
\end{tabular}

O volume de água absorvido pela planta no sistema proposto e ainda o volume de irrigação estimado pelo método de Penman-Monteith constituem as Figuras 24 e 25 , apresentando a primeira os resultados com o sistema trabalhando com uma carga hidráulica de $10 \mathrm{~cm}$ c. a. no centro da cápsula porosa $\left(\mathrm{H}_{1}\right)$, no período de 26 de agosto a 6 de outubro ( $1^{\circ}$ período), enquanto a segunda mostra os resultados com o sistema trabalhando com carga hidráulica de $40 \mathrm{~cm}$ c. a. $\left(\mathrm{H}_{2}\right)$, no período de 7 de outubro a 3 de dezembro $\left(2^{\circ}\right.$ período $)$. 


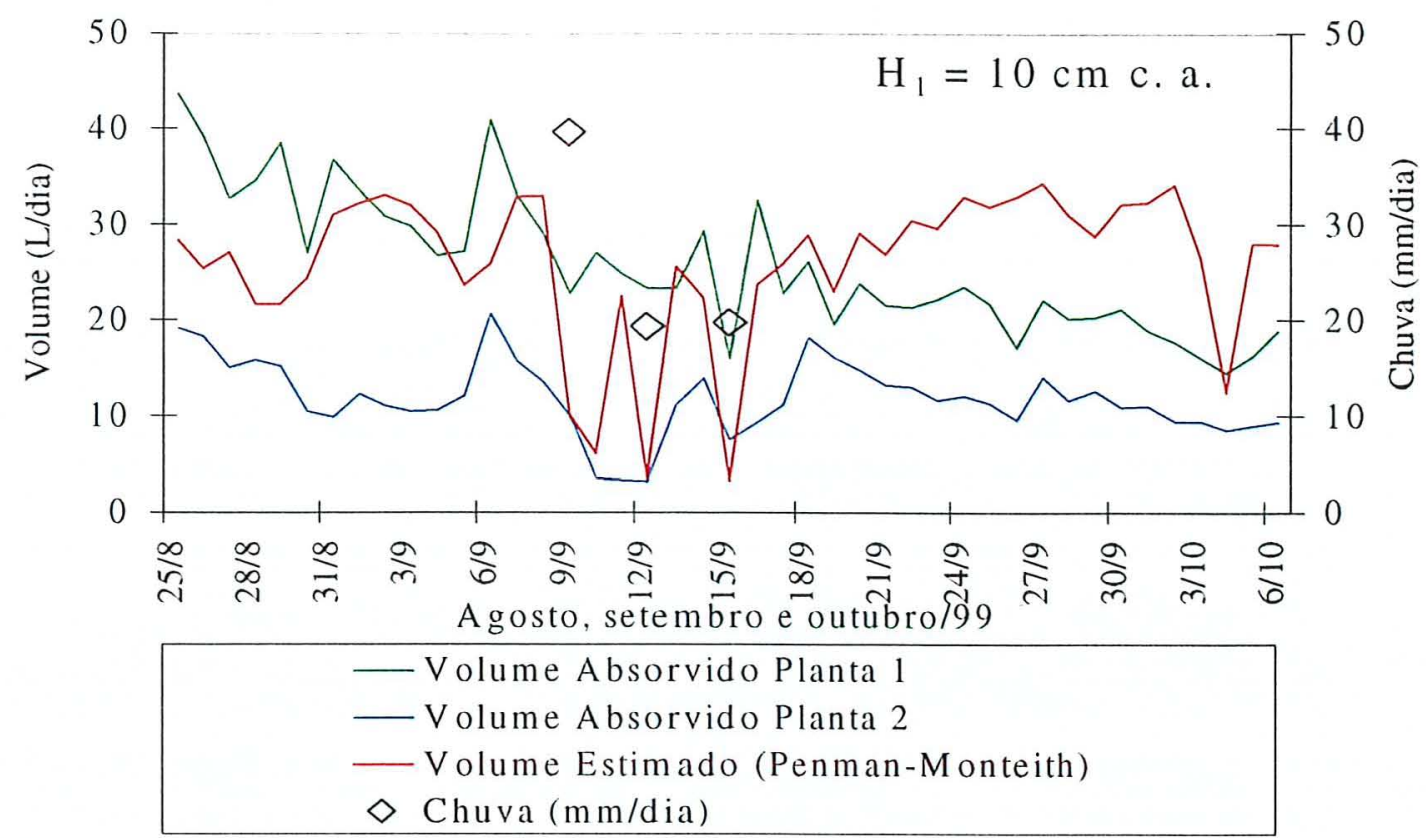

Figura 24. Volume de água absorvido pelas plantas 1 e 2 (supertensiômetro de carga constante) e volume de água estimado pela equação de Penman-Monteith, para o primeiro período analisado.

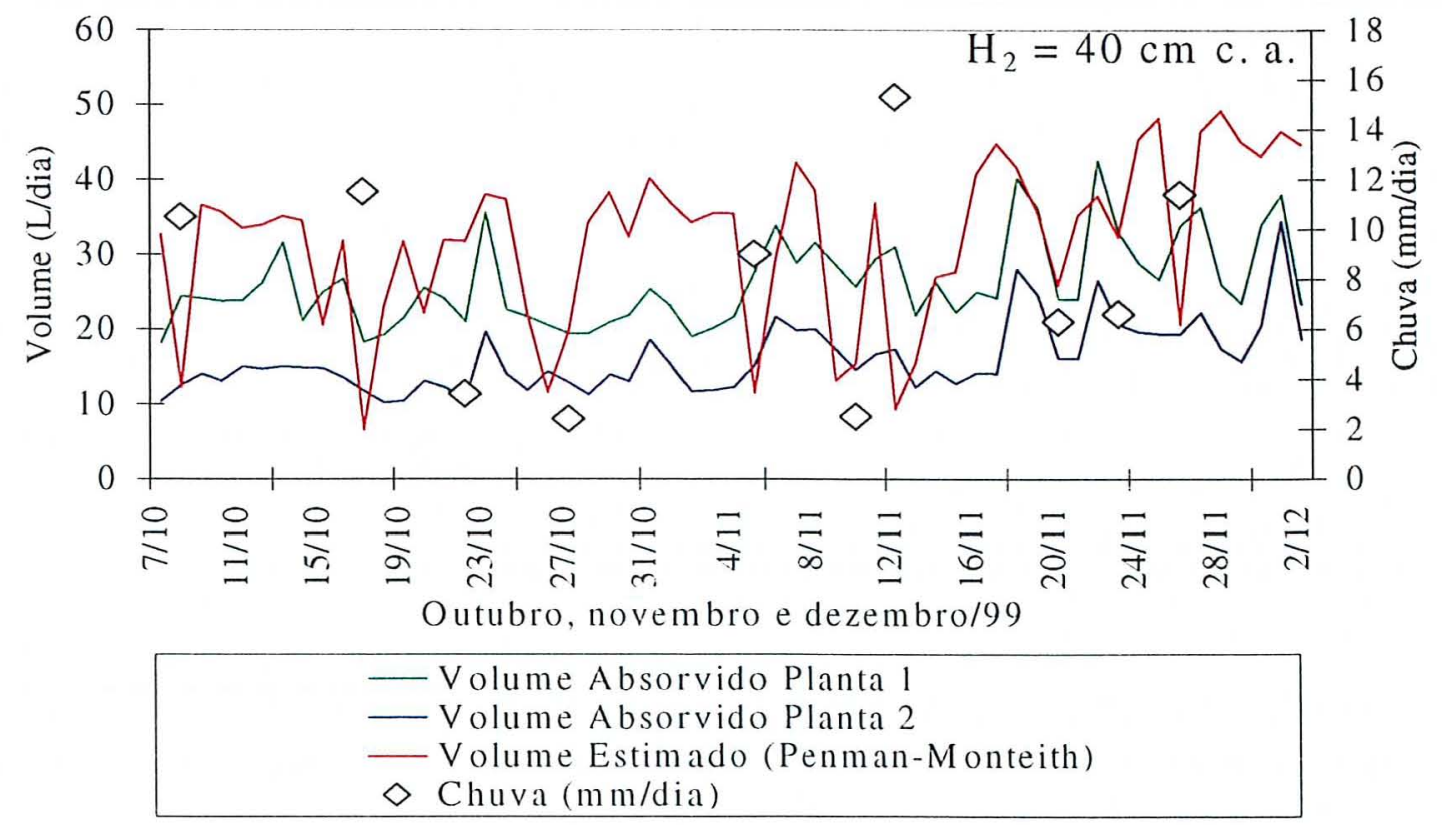

Figura 25. Volume de água absorvido pelas plantas 1 e 2 (supertensiômetro de carga constante) e volume de água estimado pela equação de Penman-Monteith, para o segundo período analisado. 
Analisando as Figuras 24 e 25, verifica-se que o sistema de fornecimento de água às plantas não correspondeu exatamente ao volume estimado de irrigação. Isso pode ser visualizado nos resultados de volume absorvido, acumulado nos períodos analisados para as plantas 1 e 2, e o volume de irrigação estimado acumulado (Tabela 8). Esses resultados mostram que a planta 1 , no primeiro período, teve $99,25 \%$ de sua necessidade hídrica suprida, enquanto a planta 2 , apenas $45,85 \%$. No segundo período analisado, a planta 1 supriu $81,99 \%$ do volume total de irrigação estimado para o período, e a planta 2 $50,66 \%$.

Tabela 8. Volumes acumulados da água absorvida pelas plantas 1 e 2 e estimado pela equação de Penman-Monteith.

\begin{tabular}{lccc}
\hline & \multicolumn{2}{c}{ Volume Absorvido (litros) } & Volume estimado (PM) (litros) \\
Período & Planta 1 & Planta 2 & \\
\hline 26/8 a 6/10 & 1108,13 & 511.98 & 1116,48 \\
$\mathbf{7 / 1 0}$ a 2/12 & 1492.08 & 922.07 & 1819.85 \\
\hline
\end{tabular}

Considerando o volume de irrigação estimado pela equação de PenmanMonteith como $100 \%$, ou seja, o volume de irrigação ideal para a máxima produção, as Figuras 26 e 27 mostram a percentagem de água absorvida pelas duas plantas, para o $1^{\circ}$ período e para o $2^{\circ}$ período, respectivamente. Analisando tais resultados, observa-se que, nos dias com precipitações naturais, ou com a umidade relativa alta, a demanda atmosférica estimada (PM) diminui significativamente. Não foi objetivo deste experimento verificar a precisão da equação de Penman-Monteith (PM) nos dias chuvosos e nem dos coeficientes $\mathrm{Kc}$ e $\mathrm{Kr}$ utilizados; com certeza algum erro de estimativa foi cometido, principalmente pelo fato de as plantas 1 e 2 estarem isoladas das chuvas e da evaporação direta do solo. Por outro lado, um certo erro experimental é também esperado da metodologia proposta de irrigação através do supertensiômetro de carga constante. Nos dias com alta demanda atmosférica, a absorção de água pela planta é elevada. fazendo com que diminua a quantidade de água disponivel nos bulbos molhados: 
já nos dias com precipitações, a demanda atmosférica é pequena. o que permite que o sistema continue a fornecer água para repor o déficit hídrico nos bulbos molhados.

Associando esses dois erros experimentais antagônicos, observa-se, nas Figuras 26 e 27, que, nos dias chuvosos, ou com umidade relativa alta, o sistema de irrigação proposto forneceu de 300 a $400 \%$ do volume estimado pela equação de PenmanMonteith. Portanto a solução do problema seria analisar somente os períodos não chuvosos e aumentar a densidade de supertensiômetros na área, para evitar oscilações do tamanho do bulbo molhado no solo. Na Figura 28, observam-se três períodos analisados, sem precipitações naturais, onde é possível verificar um comportamento bastante consistente dos dados coletados.

Para eliminar as imprecisões da equação de Penman-Monteith e dos valores de $\mathrm{Kc}$ e $\mathrm{Kr}$ para períodos chuvosos, ou com umidade relativa alta, compararam-se diretamente o consumo da planta 1 (referência, 100\%) e o consumo da planta 2. Observase que essa comparação direta somente foi possível pois as plantas 1 e 2 apresentaram um consumo de água "semelhante", na condição de sequeiro (Tabela 5). Considerando que, na planta 1, havia 64 supertensiômetros de carga constante instalados e, na planta 2, apenas 32, o volume de água absorvido nesta planta deveria ser a metade do volume referente à outra. Porém os resultados obtidos tiveram uma tendência ao aumento, ou seja, o volume absorvido pela planta 2 foi de 58 a $60 \%$ do volume requerido pela planta 1. Essa tendência de aumento com o passar do tempo indica que o sistema radicular está se adaptando gradativamente à irrigação localizada, embora não tão rapidamente quanto esperado. Isso pode ser visto na Figura 29, a qual considera o volume absorvido na planta 1 como $100 \%$ e a porcentagem requerida pela planta 2 em relação à planta 1 . Já a Figura 30 mostra o aumento percentual da atividade radicular da planta 2 , tendo como referência a planta 1 . 


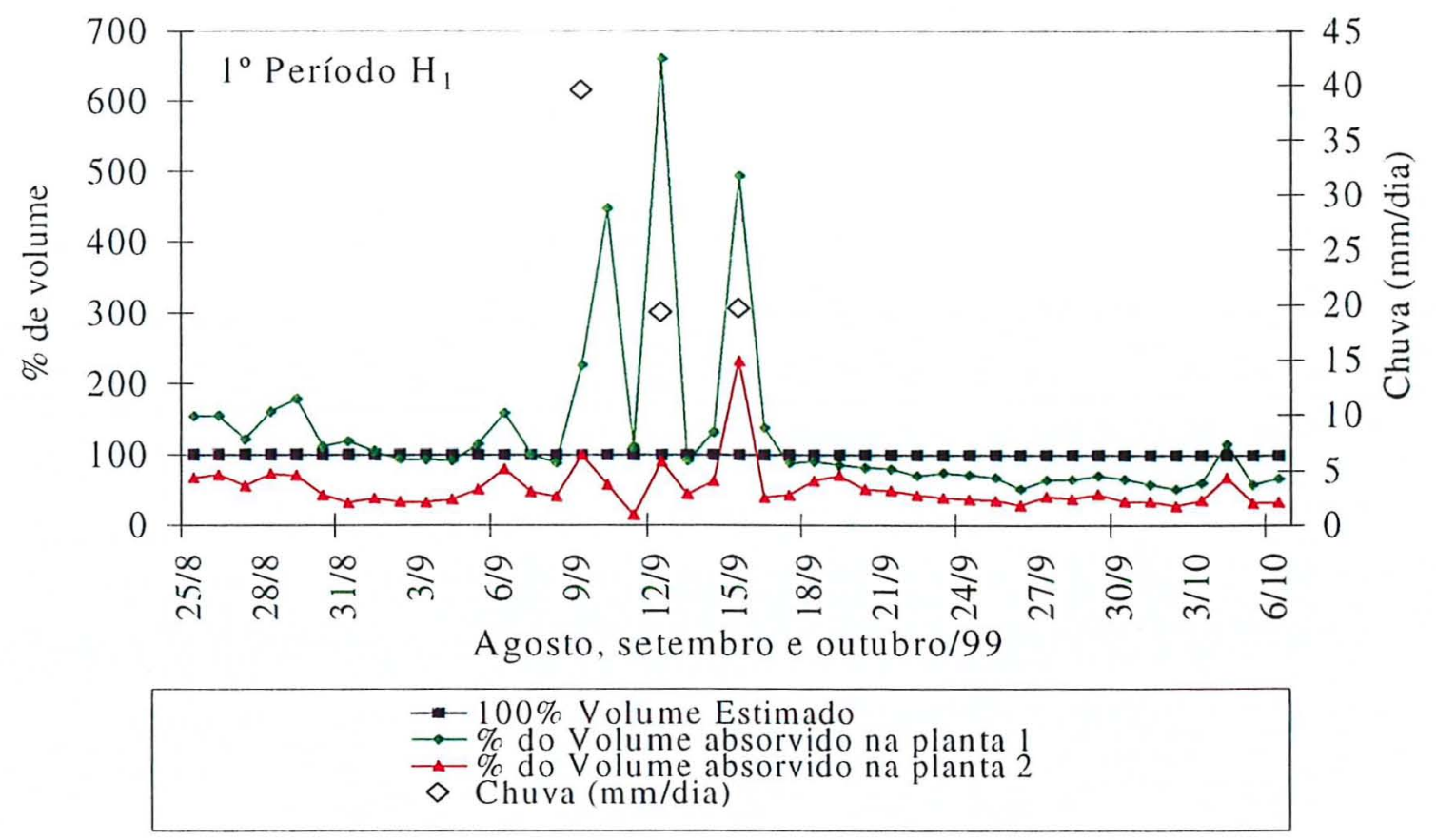

Figura 26. Análise comparativa entre a \% ideal de irrigação (vol. estimado) e os volumes percentuais absorvidos pelas plantas 1 e 2 , no $1^{\circ}$ período.

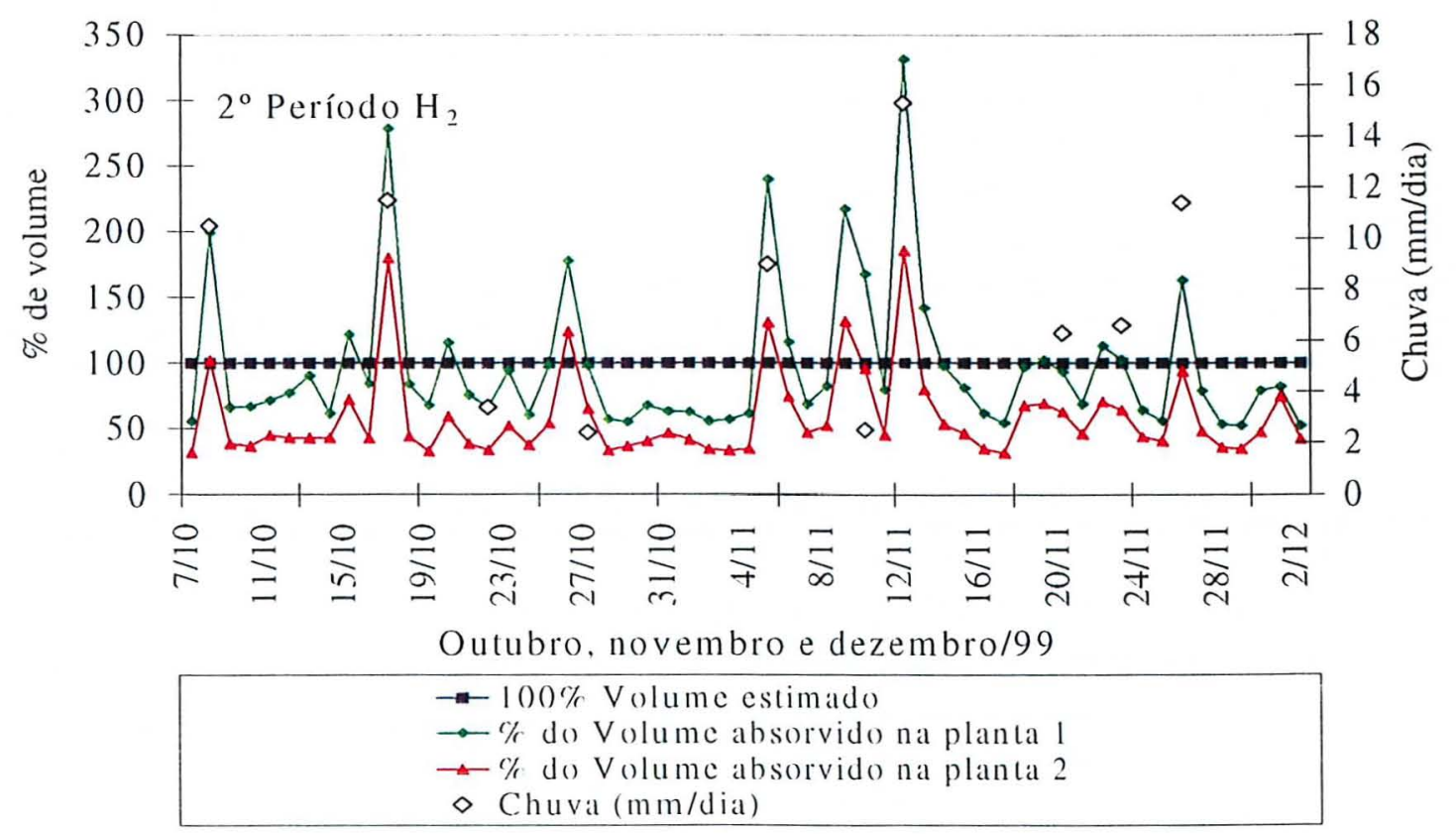

Figura 27. Análise comparativa entre a \% ideal de irrigação (vol. estimado) e os volumes percentuais absorvidos pelas plantas 1 e 2 , no $2^{\circ}$ período. 


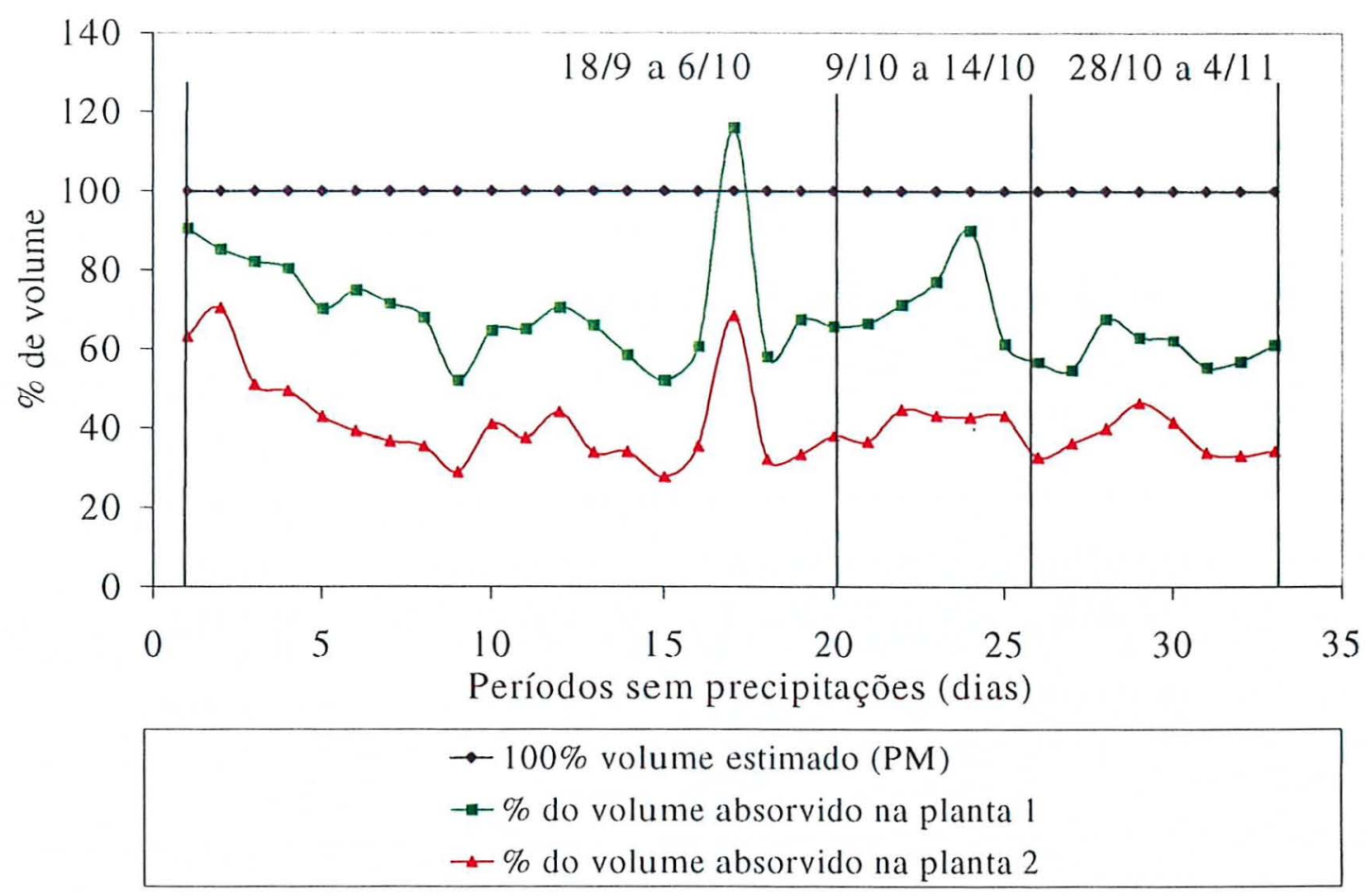

Figura 28. Análise comparativa entre a \% ideal de irrigação (vol. estimado) e os volumes percentuais absorvidos pelas plantas 1 e 2 , nos três períodos sem precipitações naturais.

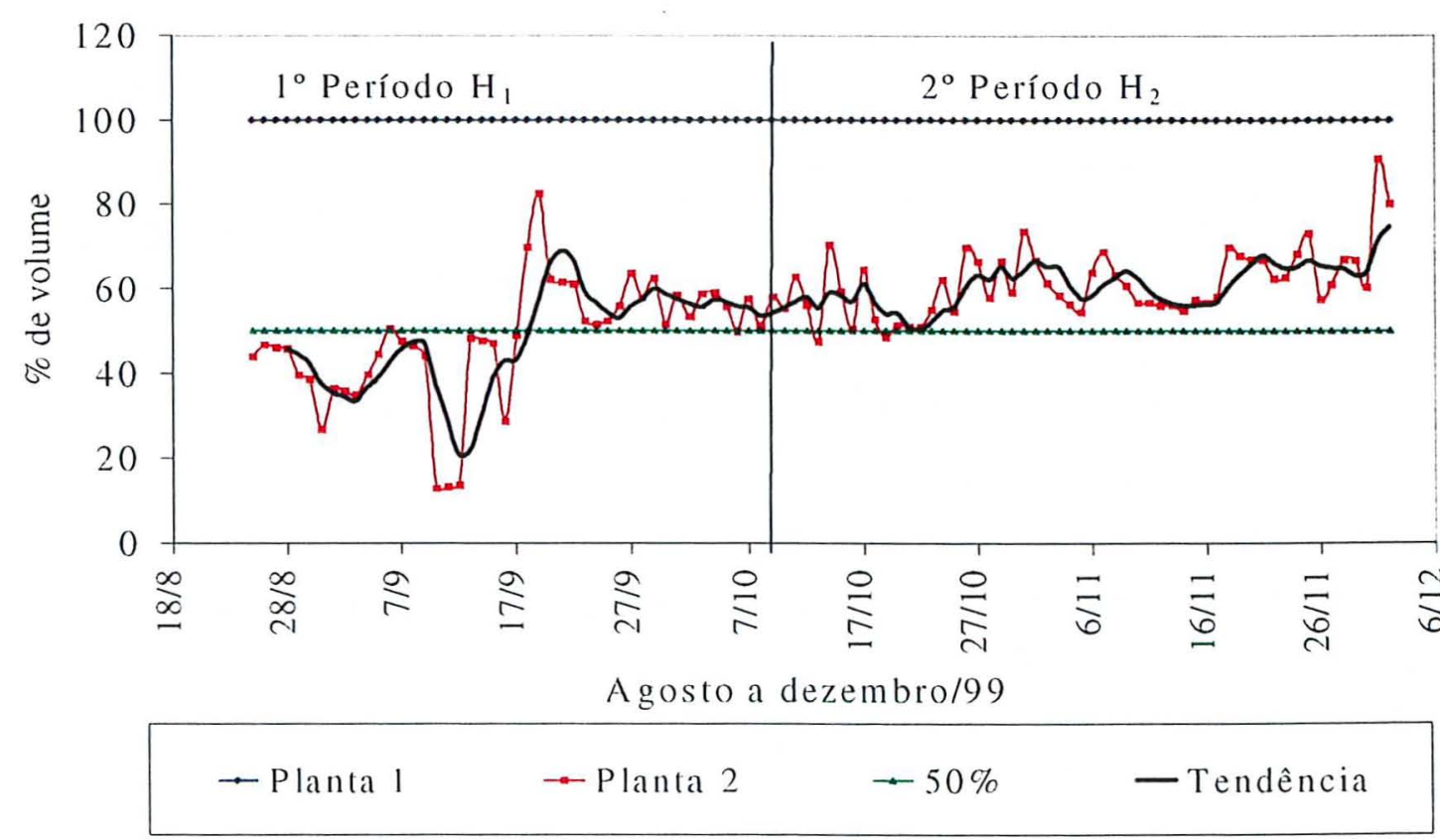

Figura 29. Volume requerido na planta 1 como $100 \%$ e a porcentagem requerida pela planta 2 em relação à planta 1 . 


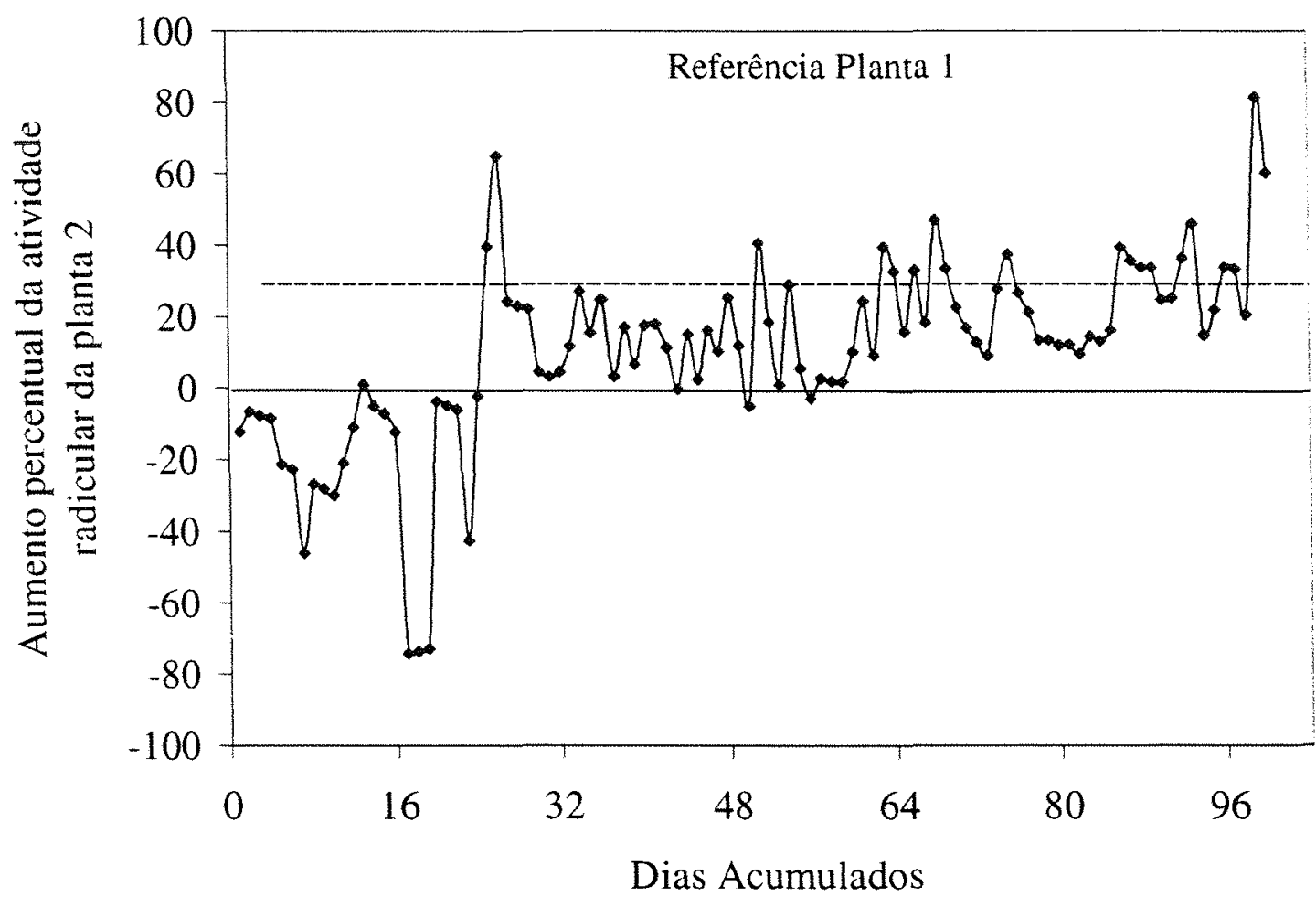

Figura 30. Aumento percentual da atividade radicular da planta 2 referente à planta 1 .

Analisando as linhas de isopotenciais mátricos, no gráfico do bulbo molhado, em função do período analisado, verificou-se que elas se mantinham constantes, principalmente na parte inferior do bulbo. O fato permite concluir que a água fornecida pelo sistema não foi lixiviada para as camadas inferiores.

$\mathrm{Na}$ estimativa da evapotranspiração da cultura, consideraram-se a evapotranspiração de referência, estimada pelo método de Penman-Monteith, o coeficiente de cultura (Kc), proposto por Vieira e Ribeiro (1993), e o coeficiente de correção pelo efeito da localização $(\mathrm{Kr})$; um outro coeficiente, porém, deve ser utilizado para corrigir o efeito da redução da área molhada por planta, o coeficiente de adaptação radicular (Kad.r.), pois analisando os resultados apresentados na Figura 29, observa-se que caso o coeficiente Kad.r. fosse desconsiderado nos cálculos da evapotranspiração da cultura, estaríamos aplicando um volume excessivo de 30 a 40\% em relação à capacidade de absorção da planta 2. 
É necessário um monitoramento preciso do aprofundamento do bulbo molhado no solo, na irrigação localizada, principalmente na fase de adaptação do sistema radicular, uma vez que o excesso de água poderá causar deficiência de aeração dentro do bulbo molhado, e, por decorrência, promover a lixiviação de adubos no perfil do solo. Não se recomenda, nessa fase de adaptação do sistema radicular, o monitoramento da irrigação unicamente por métodos climatológicos, já que não se conhece, com precisão, o valor do coeficiente de adaptação radicular (Kad.r.) da cultura.

Não foi possível, neste trabalho de pesquisa, em decorrência do tempo disponível para a conclusão do curso de mestrado. avaliar o prejuízo fisiológico que o déficit hídrico parcial na planta 2, na ordem de 30 a 40\% (Figura 29), ocasionaria em termos de emissão de floradas. de pegamento de chumbinhos e de crescimento dos frutos. Ao que tudo indica. os sintomas apresentados na copa de plantas cítricas, em portaenxertos parcialmente atacados por gomose Phytophora, - não um murchamento completo da copa, mas, sim, um secamento setorizado de determinados ramos da plantaremetem a que cada porção do sistema radicular abastece uma determinada porção da copa (sistema vascular do xilema parcialmente compartimentado). Além disso, a experiência prática, relatada pelo Eng. Zanini Junior ${ }^{2}$, em pomares cítricos irrigados com uma linha de gotejadores, indica que poderá ocorrer em determinadas circunstâncias, uma frutificação setorizada na copa da planta, apresentando os frutos produzidos um crescimento normal de pomares irrigados, e que a redução na produtividade da área se deve ao menor número total de frutos presentes na planta, e não ao menor crescimento dos mesmos.

Outra questão que se precisa analisar é que a adaptação radicular à irrigação localizada se apresenta mais eficiente com o uso da fertirrigação. Volumes de solo reduzidos, recebendo o aporte de quantidades significativas de adubos, apresentarão, a médio e longo prazos, um aumento do potencial osmótico da solução do solo e, simultaneamente uma diminuição no poder-tampão do mesmo, principalmente no que se refere aos efeitos de acidificação dos adubos na solução do bulbo molhado. O uso de

\footnotetext{
² ZANINI JUNIOR. W. Fazenda cachimbão (Schoenmaker). Comunicação Pessoal. 1999.
} 
adubos mais tecnificados (baixo índice salino, alta solubilidade, neutralidade e pureza), na citricultura fertiirrigada, poderá solucionar esse problema técnico, caso seja economicamente viável utilizar tais adubos para atender à demanda de nutrientes dos pomares cítricos fertirrigados no Estado de São Paulo. Tais fatos indicam que, quanto mais se reduz a área molhada sobre a projeção da copa, maior deverá ser a sofisticação do irrigante no manejo da irrigação e da fertirrigação. Com efeito, insucessos poderão surgir no futuro na irrigação localizada, em pomares cítricos no Estado de São Paulo, não pela incapacidade físiológica da planta cítrica em se adaptar à irrigação localizada, mas, sim, pela falta de recursos humanos, em nível de campo, para a operação tecnificada do sistema. 


\section{CONCLUSÕES}

Nas condições em que os experimentos foram conduzidos e, a partir dos resultados obtidos e discutidos no presente trabalho, podem-se estabelecer as seguintes conclusões:

a) com base nos resultados da distribuição do sistema radicular do limão 'Tahiti', determinou-se a profundidade efetiva (Pe) na linha de plantio, cujo valor foi de 0,60 metro. Com a distribuição das raízes na horizontal, verificou-se que a distância efetiva (De) é de $2.0 \mathrm{~m}$ do tronco, porém, como as copas apresentam tamanhos diferentes, pode se dizer que a De está entre 50 e $75 \%$ do raio da projeção da copa;

b) para fins de manejo da irrigação localizada, na lima ácida 'Tahiti', o posicionamento ideal dos tensiômetros deverá ficar entre 50 e $75 \%$ do raio da projeção da copa, a partir do tronco da planta, amostrando as camadas 0-20, 20-40 e 40-60 cm de profundidade. As duas primeiras camadas são utilizadas como indicadoras do momento de iniciar a irrigação $(-0,3$ a $-0,4$ bar), enquanto a terceira, para a verificação da profundidade da frente de molhamento do bulbo no solo;

c) a extrapolação do comprimento total de raízes medidas na parede da trincheira (77,06 metros), para um volume tridimensional (anéis concêntricos), altera significativamente o valor total $(5.583,30$ metros) e a distribuição percentual do comprimento de raízes. em relação à distância do tronco da planta. Tal extrapolação, a princípio, é válida somente para plantas isoladas no pomar, sem a formação de "ranking";

d) a extrapolação do comprimento total de raízes medidas, para o volume tridimensional, evidencia que a maior quantidade de radicelas se encontra do meio para o final da projeção da copa da planta, em condição de sequeiro, indicando que qualquer 
descuido por parte do citricultor, no controle das ervas daninhas, induzirá uma forte competição por água e por nutrientes, com provável redução de produtividade do pomar;

e) a atividade de absorção de água do porta-enxerto limão 'Cravo', em condição de sequeiro, na camada de $0-25 \mathrm{~cm}$ de profundidade, foi responsável pela taxa de 68 a $74 \%$ do volume de solução absorvida, valor superior, em aproximadamente $24 \%$, ao do comprimento total de raízes nessa camada (44 a 52\%), evidenciando que as raízes mais rasas apresentam maior capacidade de absorção e de condutividade hidráulica;

f) a equação de Penman-Monteith e a metodologia proposta do supertensiômetro de carga constante apresentam respostas antagônicas, em períodos chuvosos, e com alta umidade relativa, dos volumes de água evapotranspirado e absorvido pelas plantas, respectivamente, não sendo recomendada a comparação dessas metodologias em tais condições climáticas;

g) a adaptação do porta enxerto limão 'Cravo', de uma planta adulta, à irrigação localizada, sem o uso de fertirrigação e nas condições climáticas do Estado de São Paulo, demorou aproximadamente 100 dias, nesse período aumentou entre 30 e $40 \%$ a sua capacidade de absorção de água, se comparada à de uma planta com $24,2 \%$ e à de outra com $12,2 \%$ da projeção da copa irrigada. Não foi objetivo deste trabalho avaliar o prejuízo fisiológico que o déficit hídrico parcial, nesses 100 dias, ocasionou em termos de pegamento de florada e de fixação de chumbinhos na planta com menor área irrigada;

h) não se recomenda, nesta fase de adaptação do sistema radicular, o monitoramento da irrigação unicamente por métodos climatológicos, uma vez que não se conhece, com precisão, o valor do coeficiente de adaptação radicular (Kad.r.) da cultura. 


\section{SUGESTÕES}

Face às dificuldades de campo para trabalhar com a amostragem de todo o sistema radicular de uma planta cítrica adulta, recomenda-se, em futuros trabalhos de adaptação do sistema radicular à irrigação localizada, amostrar áreas bem menores debaixo da copa da planta, de tal forma a possibilitar um delineamento estatístico do experimento, cujos resultados possam, posteriormente, ser extrapolados para o volume total abrangido pelo sistema radicular.

Recomenda-se a aplicação de hipoclorito de sódio e de ácido fosfórico continuamente na água de abastecimento do supertensiômetro de carga constante, para evitar eventual entupimento da cápsula porosa, pela formação de uma mucilagem de alga e bactéria no interior da cápsula.

A metodologia proposta do supertensiômetro de carga constante apresenta um potencial muito grande de substituição de lisímetros, na estimativa da evapotranspiração real das culturas. Especial atenção deverá ser dada à densidade de cápsulas porosas instaladas no campo, uma vez que o diâmetro molhado do bulbo formado no solo estudado foi aproximadamente de $30 \mathrm{~cm}$.

Ao que tudo indica, a adaptação do sistema radicular de citros à irrigação localizada poderá ser acelerada com o uso da fertirrigação. Seria oportuno que futuros trabalhos científicos viessem a estudar os efeitos de diferentes dosagens e combinações de nutrientes na adaptação à irrigação localizada de diferentes porta-enxertos de citros. 


\section{REFERÊNCIAS BIBLIOGRÁFICAS}

ALBRIGO, L.G. Rootstocks affect 'Valencia' orange fruit quality and water balance. Proceeding International Society of Citriculture, v.1, p. 62-65, 1977.

ARRUDA, F. B. Necessidade de água nas culturas - elementos de projeto. In: CURSO PRÁTICO INTERNACIONAL DE AGROMETEOROLOGIA PARA A OTIMIZAÇÃO DA IRRIGAÇÃO, 3. Campinas, 1989. Anais... 35p

ARRUDA, F. B.; FUJIWARA, M.; CALHEIROS, R. de O.; PIRES, R. C. de M.;

SAKAI, E. A agricultura irrigada ante a administração dos recursos hídricos do Estado de São Paulo. Laranja, v. 15, n. 2, p. 243-364, 1994.

BERNARDO, S. Manual de irrigação. 6.ed. Viçosa: Imprensa Universitária, 1995. $657 \mathrm{p}$.

BEZERRA, F. M. L. Coeficientes de cultura e efeitos de déficits hídricos nos diferentes estádios fenológicos sobre a produção de batata (Solanum tuberosum, L.). Piracicaba. 1995. 131p. Tese (Doutorado). Escola Superior de Agricultura "Luiz de Queiroz", Universidade de São Paulo.

BIELORAI, H. The effect of partial wetting of the root zone on yield and water use efficiency in a drip and sprinkler-irrigated mature grapefruit grove. Irrigation Science. v. 3, p.89-100, 1982.

BLACK, J.D.F. The basis of tricle irrigation. Tricle irrigation. Ferntree Gully: ICI, 1971. (Booklet).

BOHM, T.A . Methods of studyng root systems. Berlin: Spring Verlag, 1979. 330p.

BOTEON. M. Setor Cítricola. Preços Agrícolas: Mercados e Negócios Agropecuários, v. 2. n. 124, p. 42-43, 1997. 
CASTLE, W.S. Fibrous root distribuition of 'Pineapple' orange trees on Rough Lemon rootstock at three tree spacings. Journal of the American Society of Horticultural Science, v. 105 , n. 3, p. 478-480, 1980.

CASTLE, W.S.; KRESDORN, A. H. Effects of citrus rootstock on root distribuition and leaf mineral content of 'Orlando' tangelo trees. Jornal of American Society of Horticultural Science, v. 100, p. 1-4, 1975.

CASTLE, W.S.; KRESDORN, A. H. Soil water use and apparent root efficiensis of citrus trees on four rootstocks. Jornal of American Society of Horticultural Science, v. 12, p. 403-406. 1977.

CASTLE, W.S.;TUCKER, D.P.H.; KREZDORN, A.H.; YOUTSEY, C. Rootstocks for Florida citrus. Grainesville: University of Florida, Institute of Food and Agricultural Science, 1989. 47 p.

CASTRO P. R. C. Comportamento dos citrus sob defícit hídrico. Laranja, v. 2, n. 15, p. 139-154, 1994.

CHAPOT, H. The citrus plant. In: HÄFLIGER, E. (Ed). "Citrus", Basel: Ciba Geigy, 1975, p. 6-13, (Techinical Monography, 4).

COELHO FILHO, M. A. Variabilidade espacial aplicada ao manejo da irrigação por microaspersão em lima ácida 'Tahiti' (Citrus latifolia TANAKA). Piracicaba, 1998, 152p.. Dissertação (Mestrado), Escola Superior de Agricultura "Luiz de Queiroz", Universidade de São Paulo.

COWAN, I. R. Regulation of water use in relation to carbon gain in higher plants. In:

LANGE, O. L; NOBEL, P. S.; OSMOND, C. B.; ZIEGLER, H., (Ed). Physiological plant ecology. II. Water relations and carbon assimilation. Berlin: Springer-Verlag. 1982, v. 12B, p. 589-613. (Encyclopedia of plant physiology).

CRESTANA, S.: GUIMARÃES, M. F.; JORGE, L. A. C.; RALISCH, R.; TOZZI, C. L.; TORRE, A.; VAZ, C. M. P. Avaliação da distribuição de raízes no solo auxiliada por processamento de imagens digitais. Revista Brasileira de Ciência do Solo, v.18, n.3, p. 365-371, set./dez. 1994.

DOORENBOS. J.: KASSAM. A .M. Efeito da água no rendimento das culturas. Campina Grande. UFPB, 1979, 306p. (Estudos FAO: Irrigação e Drenagem. 33.) 
DOURADO NETO, D.; NIELSEN,D.R.; HOPMANS,J.W.; PARLANGE, M.B. Curva de retenção: SWRC v.2.00p. Piracicaba: FAPESP/BRASIL,1996.

DOWTON, W. J. S.; LOVEYS, B.R.; GRANT, W.J.R. Non-uniform stomatal closure induced by water estress cause putative non-stomatal inhibition of photosynthesis. New Phytology, v. 110, p. 503-509, 1988.

FEICHTENBERGER, E. Gomose de Phytophthora dos citrus. Laranja, v. 11, n. 1, p. 97-122, 1990.

FNP. CONSULTORIA \& COMERCIO. AGRIANUAL 2000: Anuário estatistíco de agricultura brasileira. São Paulo, 2000.

FORD, H. W. The distribuition of feeder roots of orange and grapefruit trees on rough lemon rootstock. Citrus Magazine, v. 14, p. 22-23, 1952.

FORD, H. W. The effect of rootstock, soil type, and soil $\mathrm{pH}$ on citrus root growth in soil subject to flooding. Proceedings Florida State of Horticulture Society, v. 77, p. $41-45,1964$.

GIORGI DI, F., YASUHIRO, B., KELSON DIB, I., MARCHI, R. J., TRIBONI, H, R., WAGNER, R. L., ANDRADE, G. Influência climática na produção de laranja. Laranja, v.1, n. 12, p. 163-192, 1991.

GIRITON, R. E. The growth of citrus seedlings as influenced by enviromental factors. University of California Agriculture Science. V.5, p. 83-117, 1927.

GOELL, A. Fisiologia da irrigação. In: SEMINÁRIO INTERNACIONAL DE CITROS, 2, Bebedouro, 1992. Anais. Bebedouro: Fundação Cargil, 1992. P. 173-181.

GOMES, E. M. Estudo comparativo do sistema radicular de citros sob três tipos de irrigação. Campinas: UNICAMP, 1996. Dissertação (Mestrado), FEC UNICAMP.

GRAGORY, P. J. Growth and fncioting of plant roots. In: WILD, A. Russell's soil conditions and plant growth. 17.ed. New York: Jonh Wiley, 1988. Cap. 4, p. 113167.

GREEN, S. R., CLOTHIER, B. E., McLEOD, D. J. The response of sap flow in apple roots to localized irrigation. Agricultural Water Management v.33, p. 63-78. 1997. 
GREEN, S. R., CLOTHIER, B.E. Root water uptake by kiwifruit vines following partial wetting of the root zone. Plant and soil v.173, p. 317-328, 1995.

HALE, M. G. \& ORCUTT, D. M. The Physiology of plants under stress. New York: John Willey, p. 26-43, 1987.

HILGEMAN, R. H. Response of Citrus Trees to Water Stress in Arizona. Fertilizing through grip irrigation systems on orange trees. Proceedings of the International Society of Citriculture, v. 1, p. $70-74,1977$.

HILLEL, D.A.; KRENTOS, V.K.; STILIANOV, Y. Procedure and test of na internal drainage method for measuring soil hydraulic characterirtics in situ. Soil Science, v.114, p.395-400, 1972.

JORGE, L. A. C.; Recomendações práticas para aquisição de imagens digitais analisadas através do SIARCS. São Carlos: CNPDIA/EMBRAPA, 1996. 52p. (Circular Técnica, ${ }^{\circ}{ }^{\circ}$ )

JORGE, L. A. C.; Recomendações práticas para utilização do SIARCS 3.0 nos estudos de raizes, cobertura vegetal, folhas e outras aplicações. São Carlos: CNPDIA/EMBRAPA, 1996. 22p. (Recomendação Técnica, n. ${ }^{\circ}$ 4)

KAUFMANN, M. R. Citrus a case study of enviromental effects on plant water relations. Proceedings of International Society of Citriculture, v.1, 1977.

KHAIRI, M. M. A.; HALL. A. E. Temperature and humidity effects on net photosyntessis and transpiration of citrus. Phisiology Plantarum, v. 36, p. 29-34, 1976.

KOO, R.C.J.; SMAJSTRLA, A. G. Effects of trickle irrigation methods and amounts of water applied on citrus yields. Proceedings of Florida State Horticultural Science. v. 97; p. 3-7, 1984.

KRIEDEMANN, P. E.: BARRS, H. D. Citrus orchards. In: KOZLOWSKI, T.T., Water deficits and plant growth. VI. Woody plant communities. p. 325-418, 1981.

LABOREM, E. G.; WAGNER. M.; REYES, F. Proline concentration as an indicator of water deficit in three citrus rootstocks. Fruits, v.46, n. 3, p. 259-264, 1991.

LIBARDI, P.L. Dinâmica da água no solo. Piracicaba. o autor, 1995. 497p. 
LOURENÇO, L.F.; COELHO, R.D. Determinação do coeficiente de cultivo (kc) para tangerina murcote irrigada por gotejamento. In: CONGRESSO DE INICIAÇÃO CIENTÍFICA DA ESALQ 13², Piracicaba, 1999. Anais. Piracicaba: ESALQ, 1999.

MACHADO, E. C.; LAGÔA, A. M. M. A.. Trocas gasosas e condutância estomática em três espécies de gramíneas. Bragantia, v. 53, p. 141-149, 1994.

MAGALHÃES, A. C. Considerações sobre a fisiologia do sistema radicular: o caso das plantas cítricas. Laranja, v.2, n.9, p.401-404, 1988.

MARCONDES, P.T.; COELHO, Y.S. Crescimento do fruto de limão 'Tahiti' (Citrus latifolia Tanaka). Revista Brasileira de Fruticultura, Cruz das Almas, v.13, n.2, p. 203-207, 1991.

MARSH, A. W. Irrigation. In: Walter Reuther. The Citrus Industry. University of California, v. 3, p. 230-279, 1968.

MEDEIROS, J.F de; Manejo da água de irrigação salina em estufa cultivada com pimentão. Piracicaba, p. 152, 1998 Tese (Doutorado), Escola Superior de Agricultura Luiz de Queiroz, Universidade de São Paulo.

MONTENEGRO, H.W.S. Contribuição ao estudo do sistema radicular das plantas cítricas. Piracicaba, 1960. 143p. Tese (Cátedra). Escola Superior de Agricultura "Luiz de Queiroz", Universidade de São Paulo.

MOREIRA, C. S. Estudo da distribuição do sistema radicular da laranja Pêra (Citrus sinensis Osbeck) com diferentes manejos de solo. Piracicaba, 1983. 143p. Tese (Mestrado). Escola Superior de Agricultura "Luiz de Queiroz", Universidade de São Paulo.

MOREIRA, C. S. Manejo de solo em pomar cítrico. Laranja, v.2, n. 9, p. 423-436, 1988.

MORESHET, S. COHEN Y; FUCHS, M. Response of mature "Shamouti" orange trees to irrigation of different soil volumes and similar levels of available water. Irrigation Science, v. 3, p. 223-236, 1983.

NEVES. C. S. V. J. Influência de sistemas de manejo em características de tangerina 'Poncã ' sobre limão 'Cravo' e de um latossolo roxo. Piracicaba, 1998. 158p. Tese 
(Doutorado). Escola Superior de Agricultura "Luiz de Queiroz", Universidade de São Paulo.

OLITTA, A. F. L. Os métodos de irrigação. São Paulo: Nobel, 1984. 267p.

OLIVEIRA, L.F.C.; VIEIRA, D.B.; SOUZA, I.S. Estudo do sistema radicular da tangerineira 'Cleópatra' com copa de laranjeira 'Pêra'. Laranja, v.19, n. 1, p. 117 $131,1998$.

ORTOLANI, A. A.; PEDRO Jr., M. J.; ALFONSI. R. R. Agroclimatologia e o de citros. In: RODRIGUES, O.; VIÉGAS, F.; POMPEU Jr., J.; AMARO A. A. (Eds). Citricultura brasileira. $2^{\circ}$ ed. Campinas: Fundação Cargill, 1991, p. 153-195.

PEARSON, W. R. Significance of rooting pattern to crop production and some problems of root research. In: CARSON, E. W., ed. The plant root and its environment. Charlottesville, University Press of Virginia, 1974. 247-270 p.

PEREIRA, A.R., VILLA NOVA,N. A., SEDIYAMA, G.C. Evapo(transpi)ração. Piracicaba: FEALQ, 1997. 183p.

PIZARRO,F. Riegos localizados de alta frecuencia. 3ed. Madrid: Mundi Prensa, 1996. $471 \mathrm{p}$.

POMPEU Jr., J. Porta-enxertos. In: RODRIGUES, O.; VIÉGAS, F.; POMPEU Jr., J.; AMARO, A.A. (Ed.) Citricultura brasileira. 2. ed.. Campinas: Fundação Cargill, 1991. v. 1, p. 265-280.

PONI, S. T., SCUDELLARI, D.N., TOSELLI, M. Influence of root pruning and water stress on growth and physiological factors of potted apple, grape, peach and pear trees. Science Horticutural. 52, 1992, p.223-236.

REICHARDT, K. A água em sistemas agrícolas. São Paulo: Manole,1990.181 p.

RODRIGUEZ, O .; INFORZATO, R..\& TEÓFILO SOBRINHO, J. Estudo do Sistema Radicular de Três tipos de Porta-enxertos para Citros. Revista Brasileira de Fruticultura, v. 1, n. 1, p.23-30, 1978.

SAAD, A .M. Uso do tensiômetro no controle da irrigação por pivô central em cultura do feijoeiro (Phaseolus vulgaris L.), Piracicaba. 1991. 144p. Dissertação (Mestrado). Escola Superior de Agricultura Luiz de Queiroz. Universidade de São Paulo. 
SAVAGE, E. M.; COOPER, W. C.; PIPER. R. B. Root systems of various citrus rootstocks. Proceedings of Florida State Horticultural Science, v. 58, p. 44-48, 1945.

SENTElHaS, P.C.; COElHO FILHO, M.A.; PEREIRA, A. P. Método agrometeorológico de estimativa da época mais adequada para indu;cão floral do limão 'Tahiti', no Estado de São Paulo. In: CONGRESSO BRASILEIRO DE AGROMETEOROLOGIA, 10, 1997. Anais, Piracicaba: SBA/ESALQ, p.41-43, 1997.

SINCLAIR T.R.; ALLEN, Jr. Carbon dioxide and water vapour exchange of leaves on fied-grown citrus trees. Jornal of Experimental Botany, v. 33, p. 1166-1175, 1982.

STEVENS, G.A. Jr.; WESTWOOD, M.N. Fruit set and cytokinin-like activity in the xylem sap of sweet cherry as affected by rootstocks. Physiologia Plantarum, v.61, p. $464-468,1984$.

TAN, C.S., BUTTERY, B.R. The effect of soil moisture stress to various fractions of the root system on transpiration, photosyntesis, and internal water relations of peach seedlings. Jornal of American Society Horticultutal Science, v.107, p.845-849, 1982.

TUBELIS, A. Clima: fator que afeta a produção e a qualidade da laranja. Laranja, v. 2,n. 16, p. 179-212, 1995.

TUBELIS, A.; SABILE, A. A. Efeito da chuva na produtividade da cultura de laranja 'Baianinha'. Laranja, v. 1, n. 12, p. 141-156, 1991.

van GENÜCHTEN, M. T. A closed form equation for predicting the hydraulic conductivity of unsaturated soils. Soil Science. American Journal 41, p.892$898,1980$.

VERMEIREN, L.; JOBLING, G. A.; tradução de GHEYI H. R.; DAMASCENO, F. A. V.; SILVA, L. G. A.; MEDEIROS, J. F. Irrigação localizada, Campina Grande, UFPB, 1980. 184 p., (Estudos FAO: Irrigação e Drenagem 36).

VIEIRA, D. B. Produtividade e irrigação. In: SIMPÓSIO DE CITRICULTURA, Jaboticabal. 1988. Anais. Jaboticabal. 1988. p. 185-193. 
VIEIRA, D. B.; RIBEIRO T. A. Estudos de parâmetros básicos de irrigação do limão 'Tahiti' (Citrus limonia Osbeck ) sob micro-aspersão. In; CONGRESSO BRASILEIRO DE ENGENHARIA AGRÍCOLA, 22. Anais. Inhéus:SBEA/CEPLAC. v.4, p.232-239, 1993.

WELLER, F. A method for studying the distribuition of absorbing roots of fruit trees. Experimental Agriculture, v. 7, p. 351-361, 1971.

WUTSCHER, K.H.; BISTLINE, F. W.. Performance of 'Hamlin' orange on 30 citrus rootstocks in southern Florida. Journal of American Society of Horticultural Science, v. 113, p. 493-497, 1988.

YELENOSKY, G. Response and adaptation of citrus trees to enviromental stresses.

Israel Jornal of Botany, v. 40, p. 239-250, 1991. 


\section{APÊNDICE 1}

Vista do sistema radicular de tangor 'Murcote' na trincheira aberta paralelamente às linhas de plantio. 


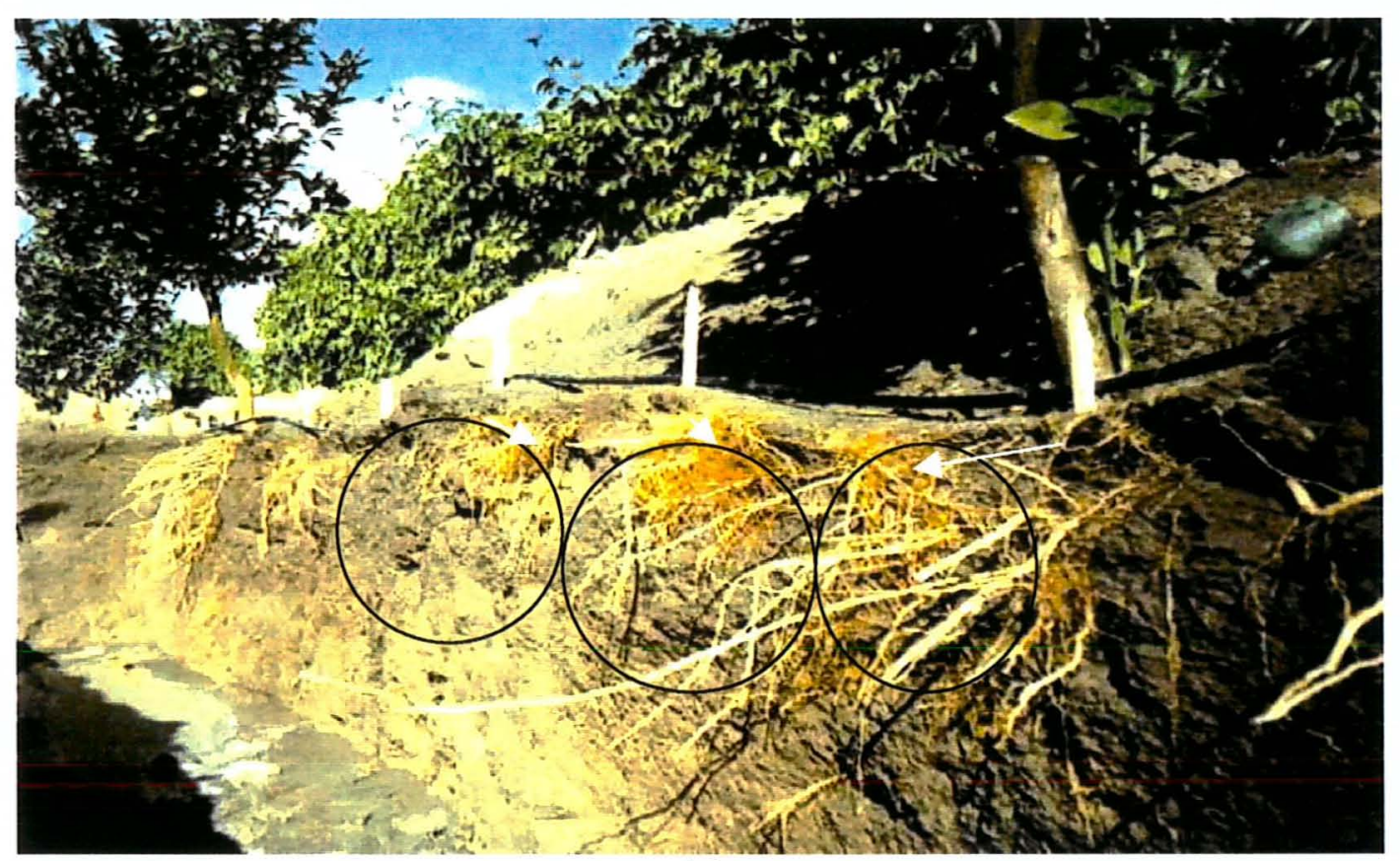

(a)

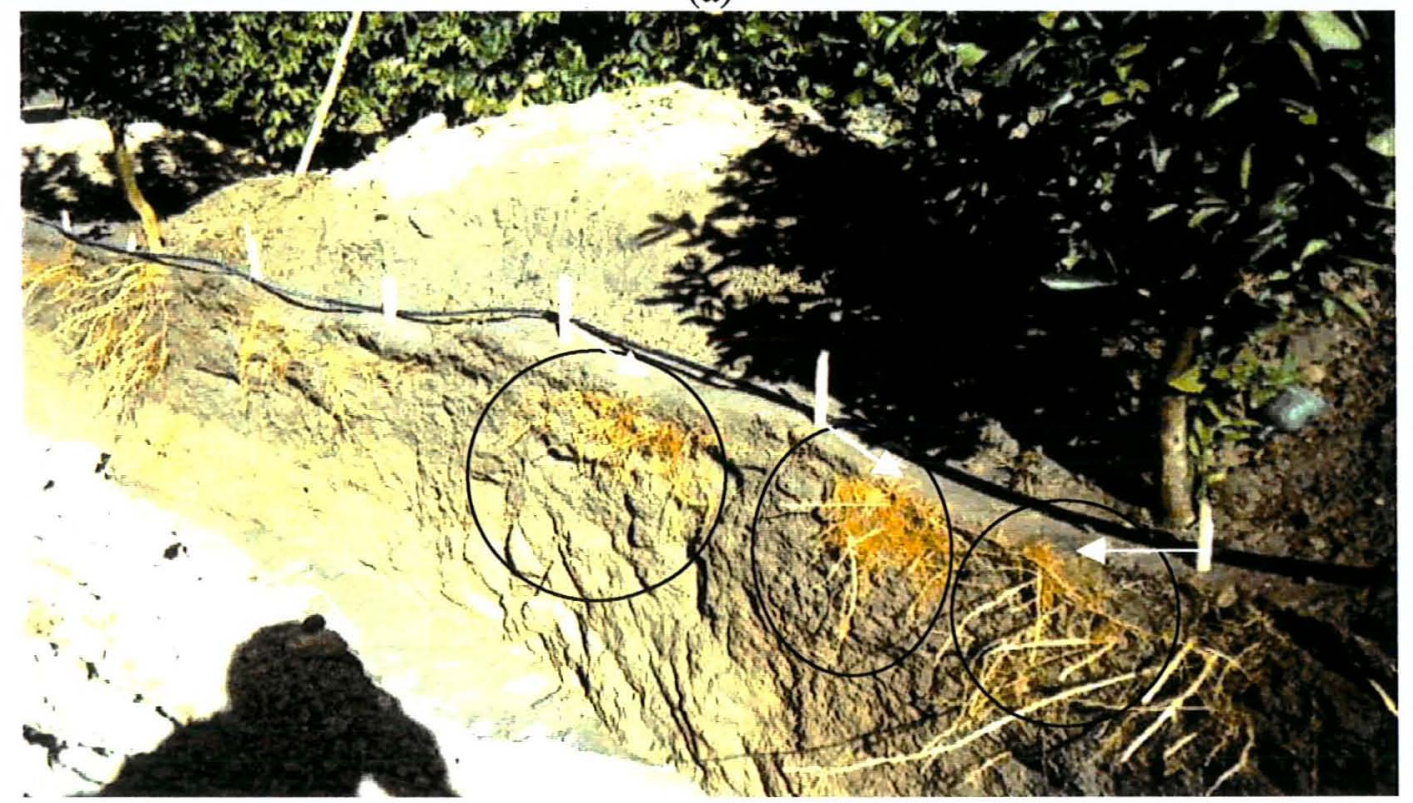

(b)

a) Vista do sistema radicular de tangor 'Murcote' dentro da trincheira aberta paralelamente às linhas de plantio. Nas estacas brancas, estão os gotejadores, porém a água escorria pela mangueira para as partes mais baixas, formando três zonas úmidas e, conseqüentemente, três bulbos de raízes bem definidos.

b) Vista do sistema radicular de tangor 'Murcote' na parede da trincheira, vista de fora da trincheira. 


\section{APÊNDICE 2}

Descrição do perfil de solo representativo da área experimental. 
PERFIL DO SOLO.

CLASSIFICAÇÃO: Terra Roxa Estruturada, eutrófica, A moderado, textura argilosa.

LOCALIZAÇÃ̃: Estado de São Paulo, município de Piracicaba, Fazenda Areão, Área Experimental de Irrigação e Drenagem da Engenharia Rural.

SITUAÇÃO E DECLIVE: Perfil descrito em uma trincheira, sob condições de vegetação artificial de mangueira. em declive suave ondulado.

ALTITUDE: $550 \mathrm{~m}$ aproximadamente.

LITOLOGIA E FORMAÇÃO GEOLÓGICA: Diabásio.

MATERIAL ORIGINÁRIO: Saprólito do Diabásio.

PEDREGOSIDADE E ROCHOSIDADE: Ausente,

RELEVO: LOCAL - Suave ondulado.

REGIONAL - suave a suave ondulado.

EROSÃO: Laminar severa.

DRENAGEM: Bem drenado.

USO ATUAL: Cultivado com limão, mangueira e outras culturas anuais.

\section{DESCRIÇÃO DO PERFIL}

Ap - 0 a $10 \mathrm{~cm}$; bruno avermelhado escuro (2,5YR 3/4,úmido), bruno avermelhado escuro (2,5YR 3/4 seco); franco argiloso; composta de grãos individuais e fraca grande granular; muitos poros grandes e médios; ligeiramente duro, friável, ligeiramente plástico e ligeiramente pegajoso; transição clara e plana.

BA - 10 a $20 \mathrm{~cm}$; bruno avermelhado escuro (2,5YR 3/4,úmido), bruno avermelhado escuro (2,5YR 3/4 seco), argila; forte média em blocos angulares; poros comuns pequenos e médios; muito duro, friável, plástico pegajoso; transição difusa e plana.

Bt1 - 20 a $56 \mathrm{~cm}$; bruno avermelhado escuro (2,5YR 3/4,úmido), vermelho escuro (2,5 YR3/6, seco); forte média em blocos angulares; poros comuns pequenos e médios; cerosidade moderada e comum; muito duro, friável, plástico e pegajoso; transição difusa e plana.

Bt2 - 56 a $97 \mathrm{~cm}$; bruno avermelhado escuro (2,5YR 3/4, úmido), vermelho escuro (2,5YR 3/6, seco); argila; moderada média e grande em blocos angulares; muitos poros pequenos; cerosidade moderada e comum; muito duro, friável, plástico e pegajoso; transição difusa e plana.

Bt3 - 97 a $127 \mathrm{~cm}$; vermelho escuro (2,5YR 3/6, úmido), vermelho escuro (2,5YR 3/6, seco); argila; moderada a forte média em blocos angulares, muitos pors pequenos; duro, friável, ligeiramente plástico e ligeiramente pegajoso: transição gradual e plana.

BC - 127 a $170+\mathrm{cm}$; vermelho escuro (2,5YR 3/6, úmido), vermelho (2,5YR 4/6, seco); argila: fraca pequena e média em blocos angulares: muitos poros pequenos; ligeiramente duro. friável, ligeiramente plástico e ligeiramente pegajoso.

RAÍZES: Muitas fasciculadas e pivotantes, médias e finas em $\mathrm{Ap}$ e $\mathrm{AB}$; poucas pivotante e finas e médias em Btl e Bt2; raras pivotantes e finas e médias em Bt3 e BC. EXAMINADORES: Francisco Ocian B. Mota e José Francismar de Medeiros. 
APÊNDICE 3

Foto área do pomar de lima ácida 'Tahiti'. 


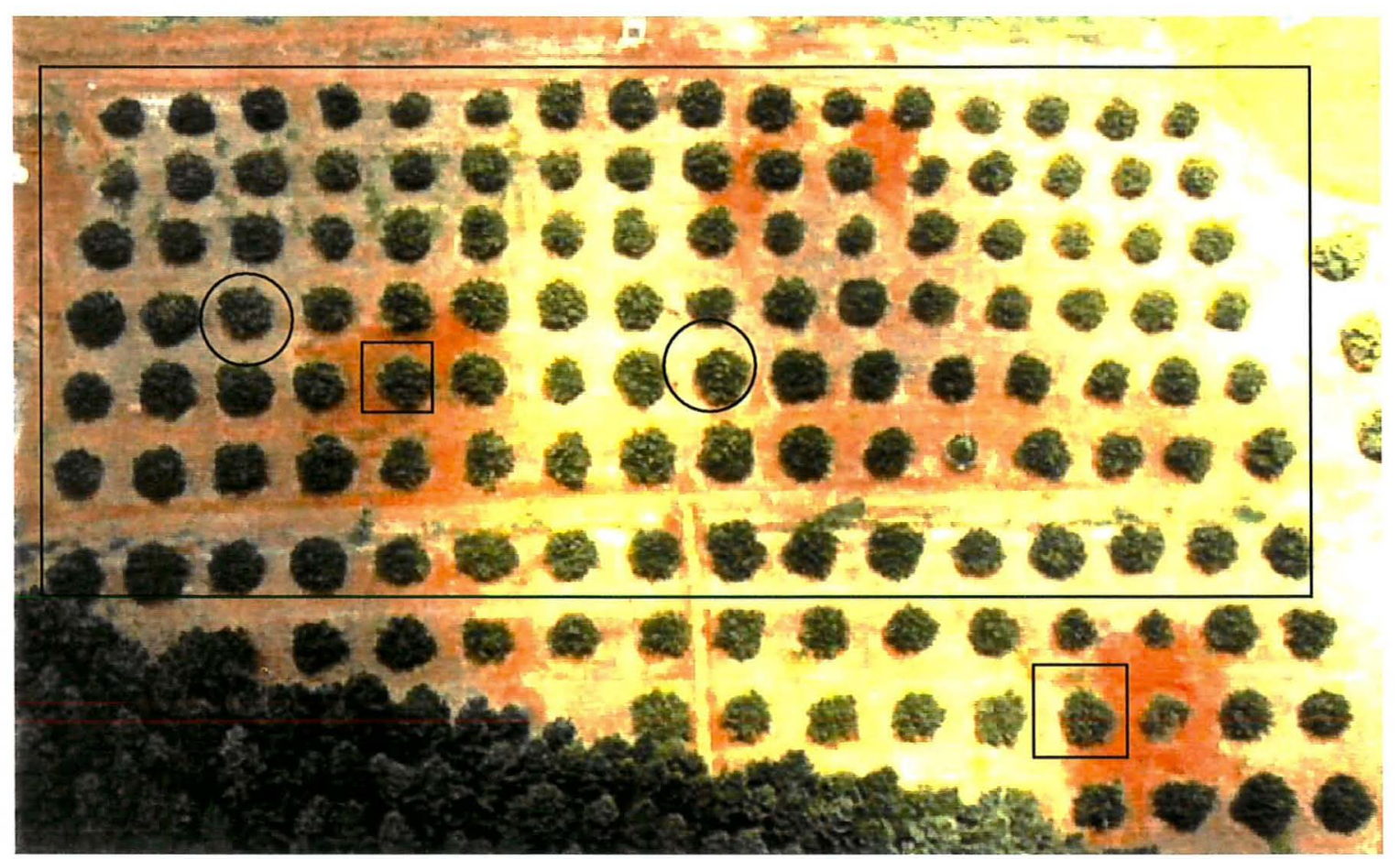

(a)

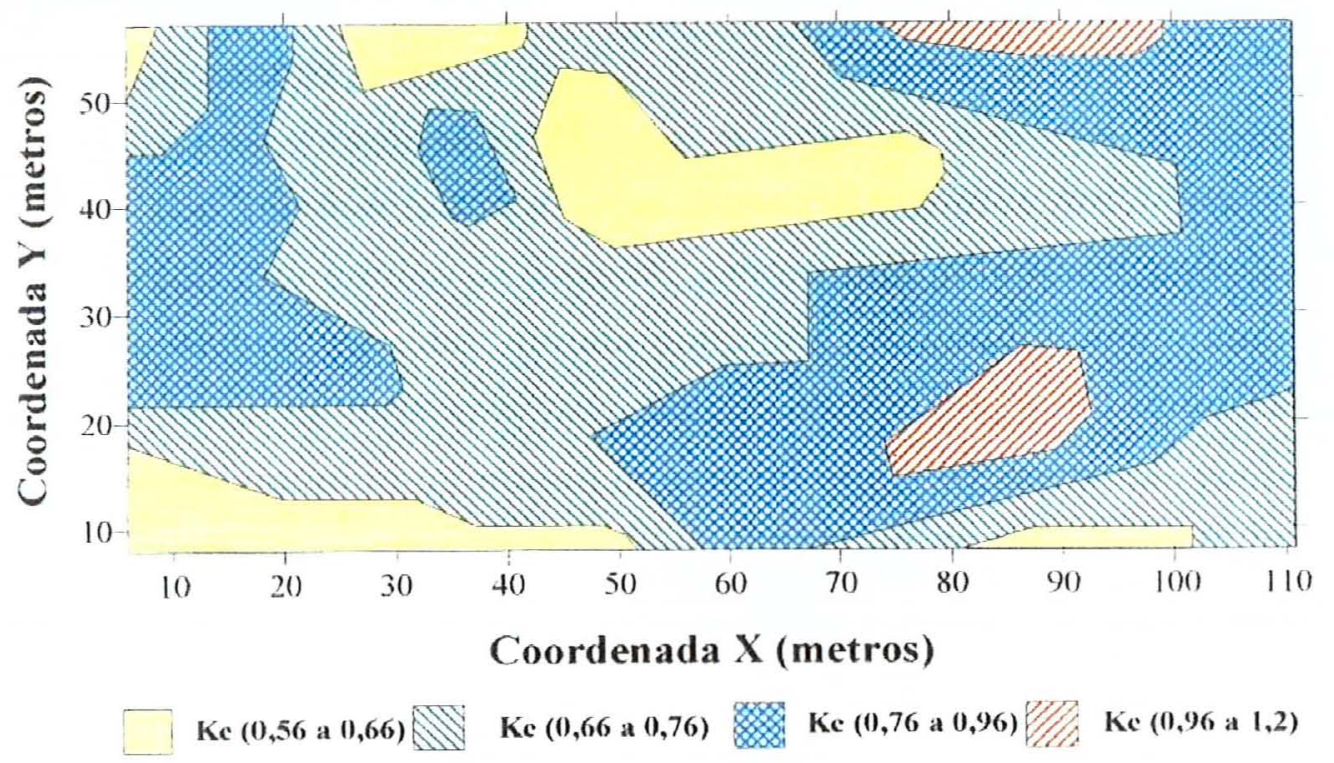

(b)

a) Foto área do pomar de lima ácida 'Tahiti', as árvores marcadas com retângulo foram utilizadas na etapa a e as com círculo, nas etapas b e c. O retângulo grande é a demarcação da área utilizada por Coelho Filho (1998).

b) Mapa do pomar de lima ácida 'Tahiti', dividido em subáreas com baixas variabilidades de consumo de solução e seus respectivos valores de $\mathrm{Kc}$ (Coelho Filho, 1998). 


\section{APÊNDICE 4}

Análise da atividade espacial do sistema radicular do porta-enxerto limão 'Cravo', por meio da variação do conteúdo de água no solo; resultados originais de todos os ciclos analisados. 


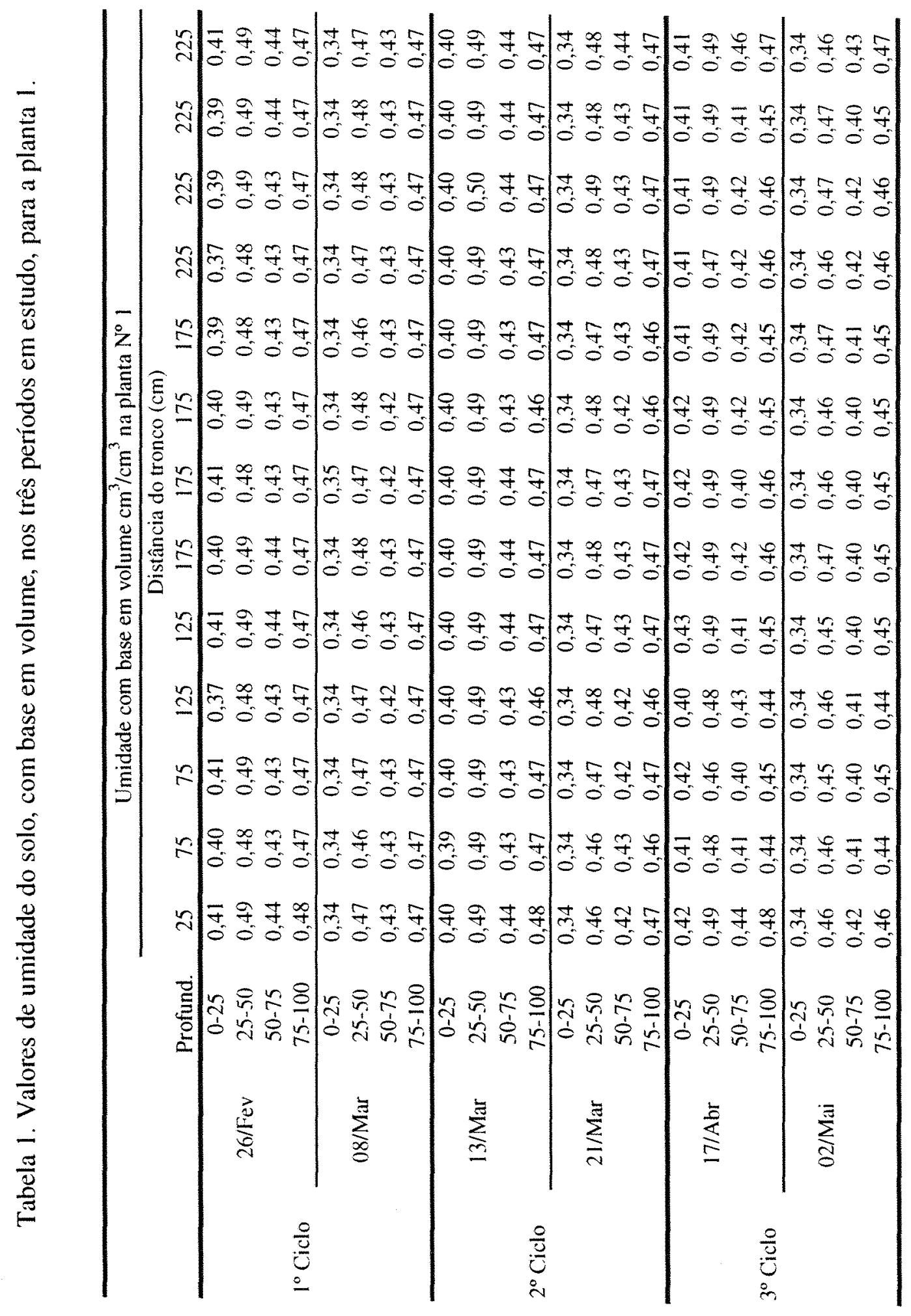




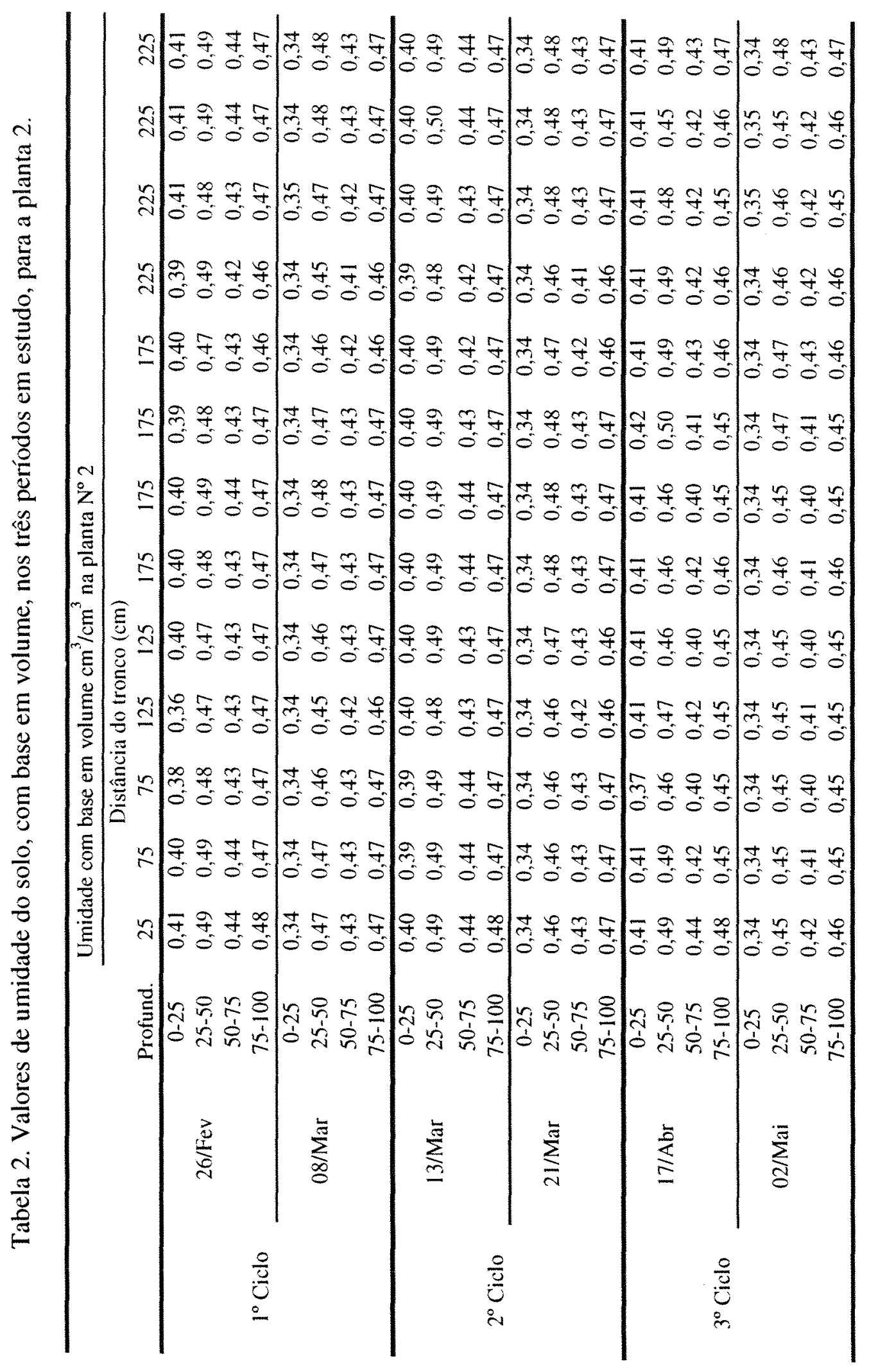




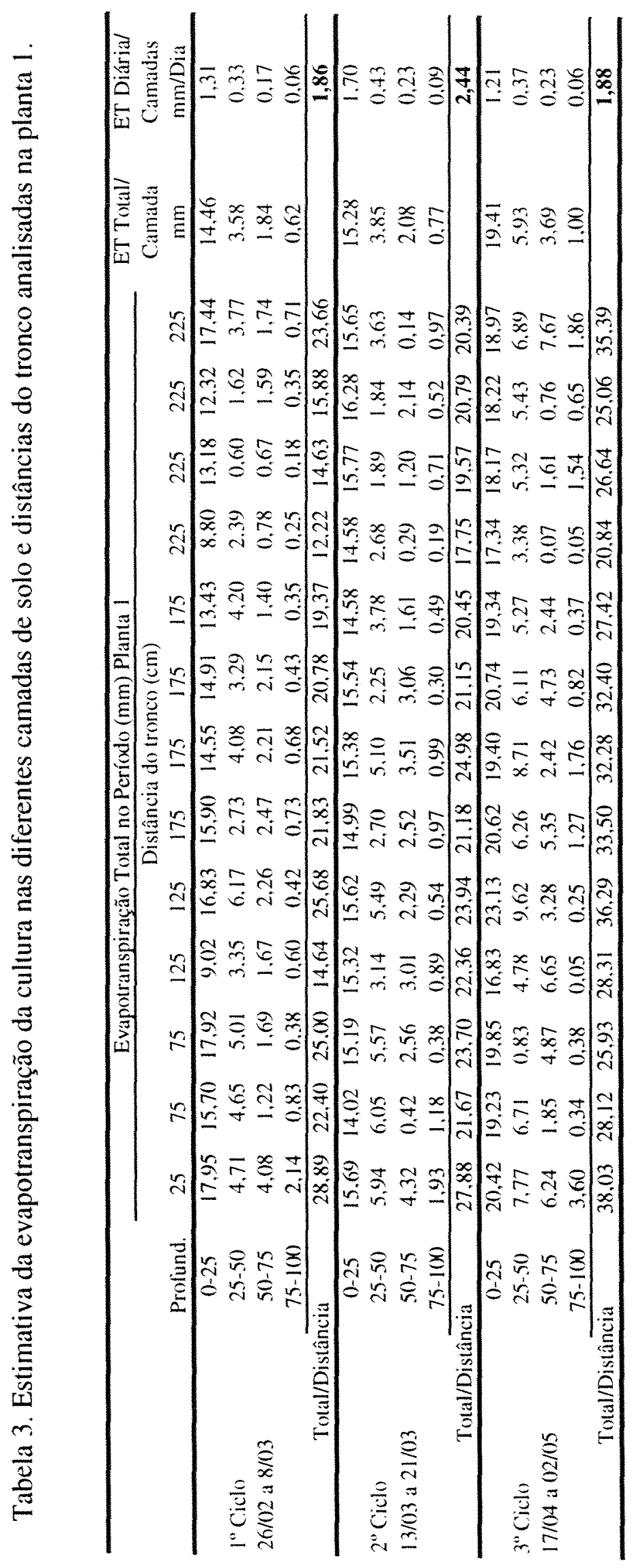




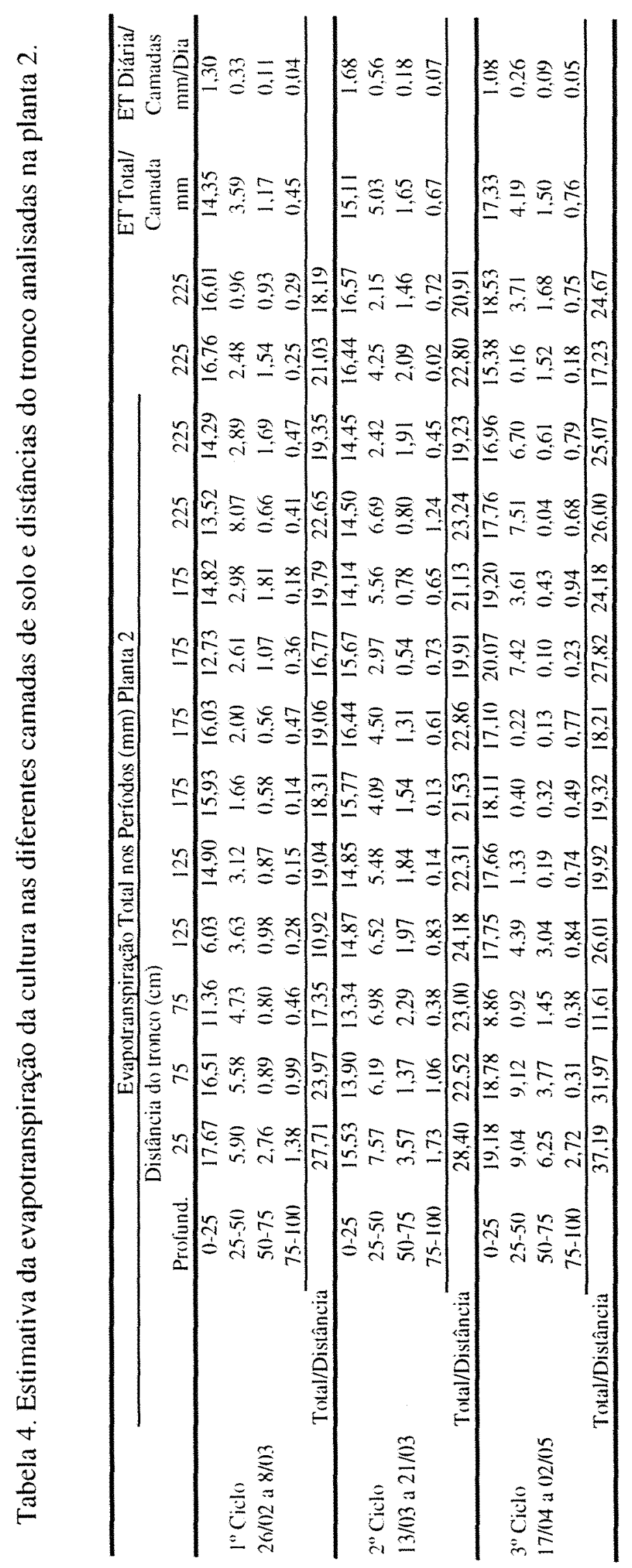




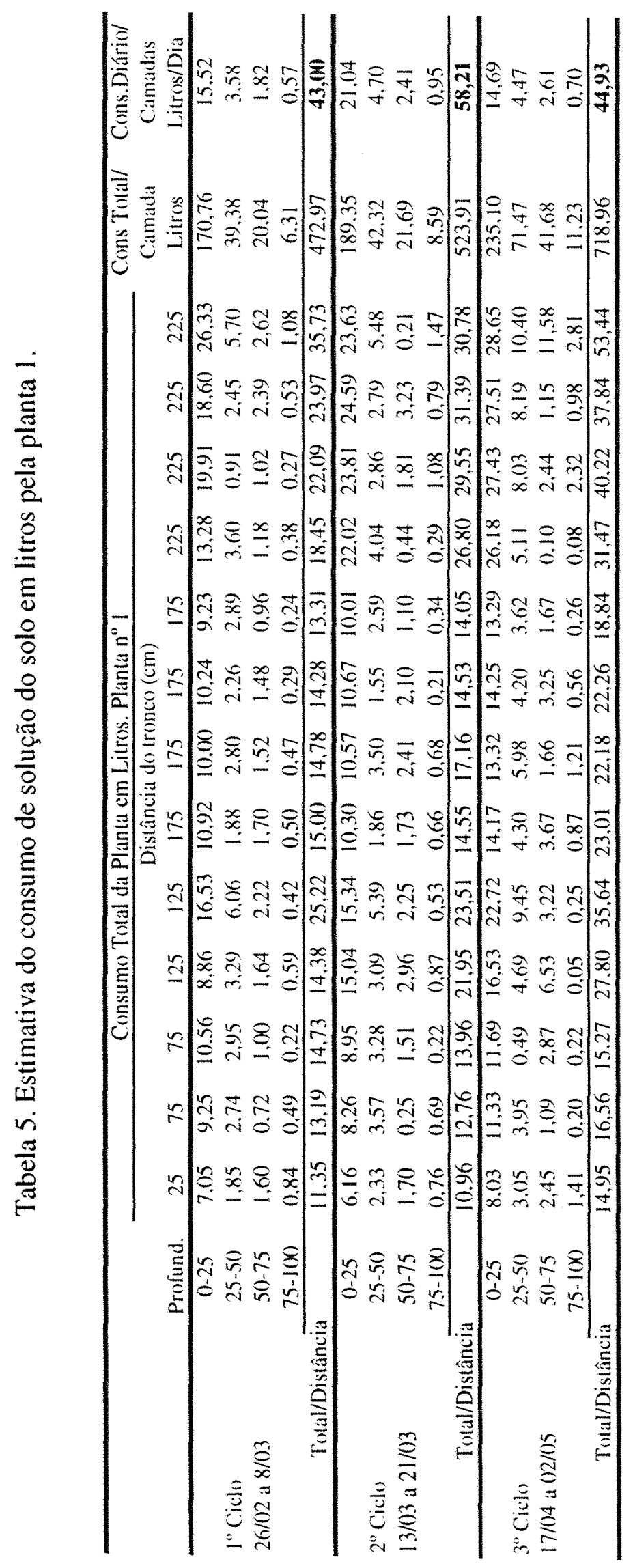




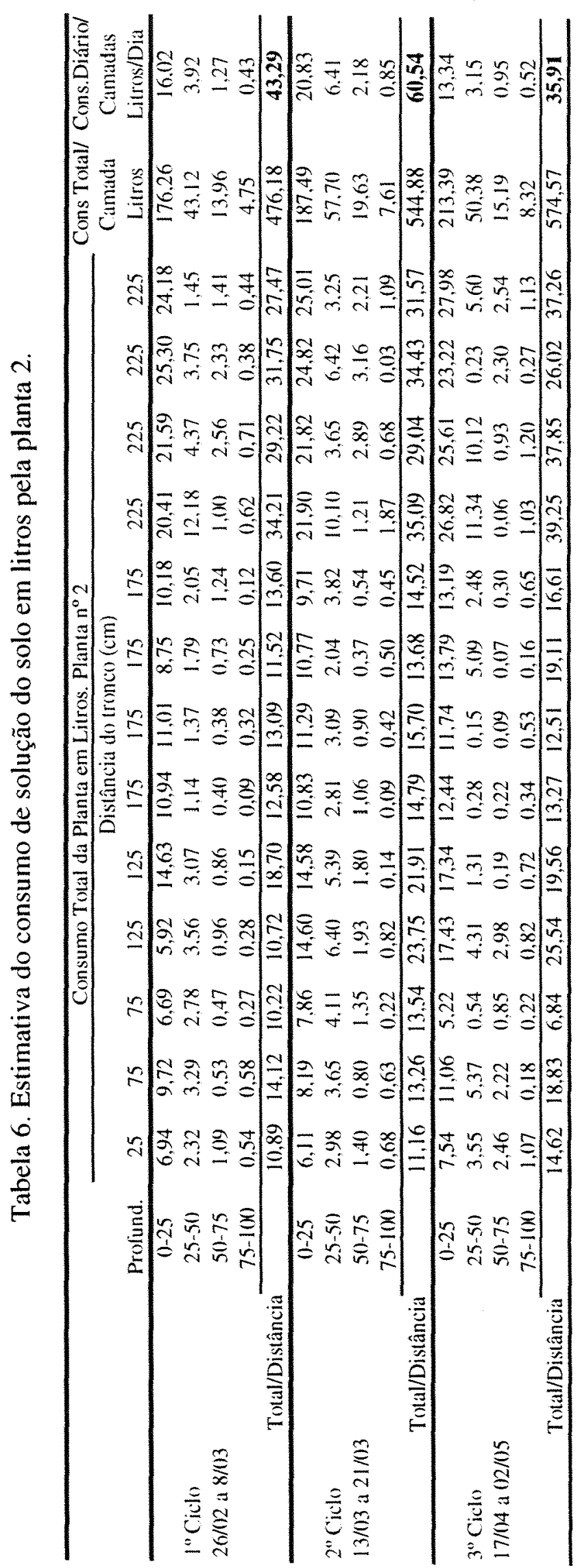




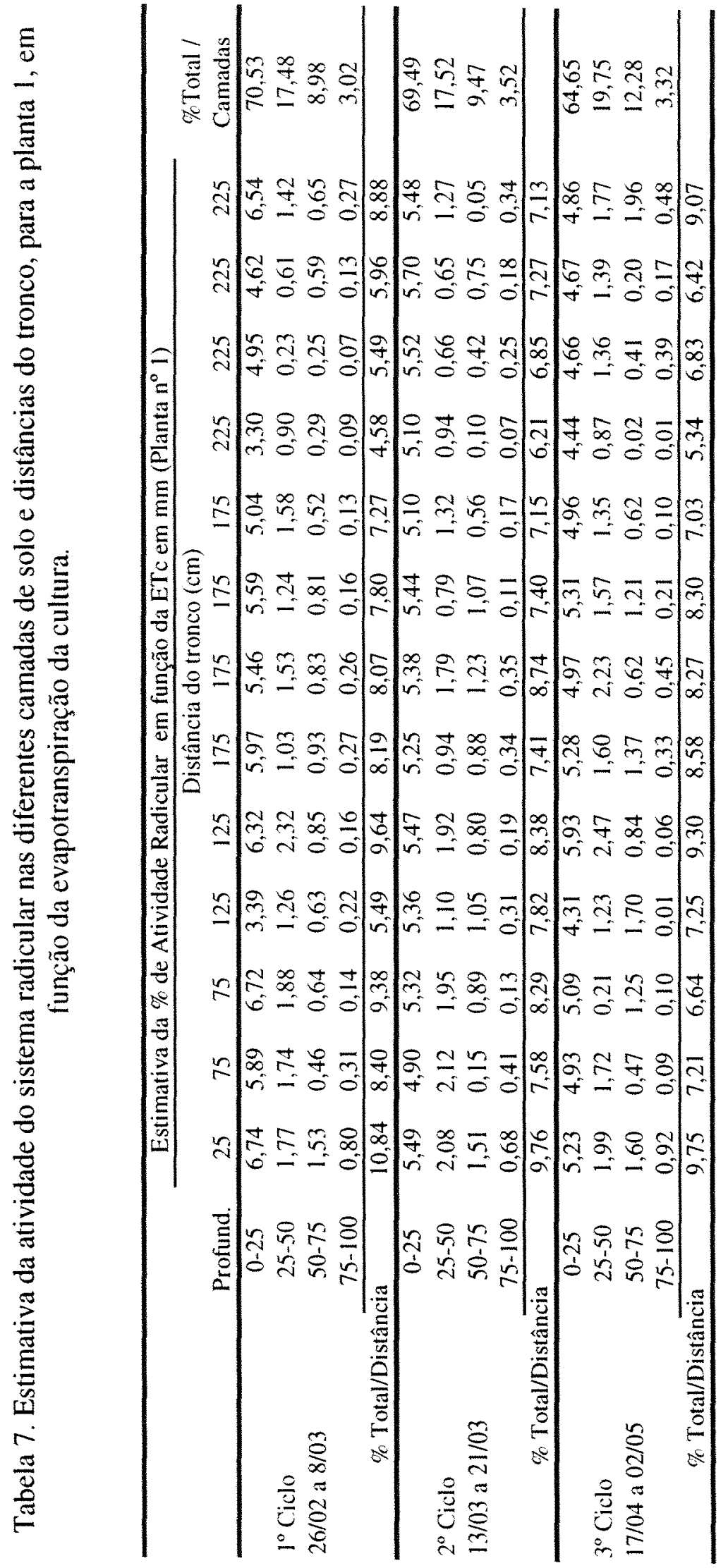




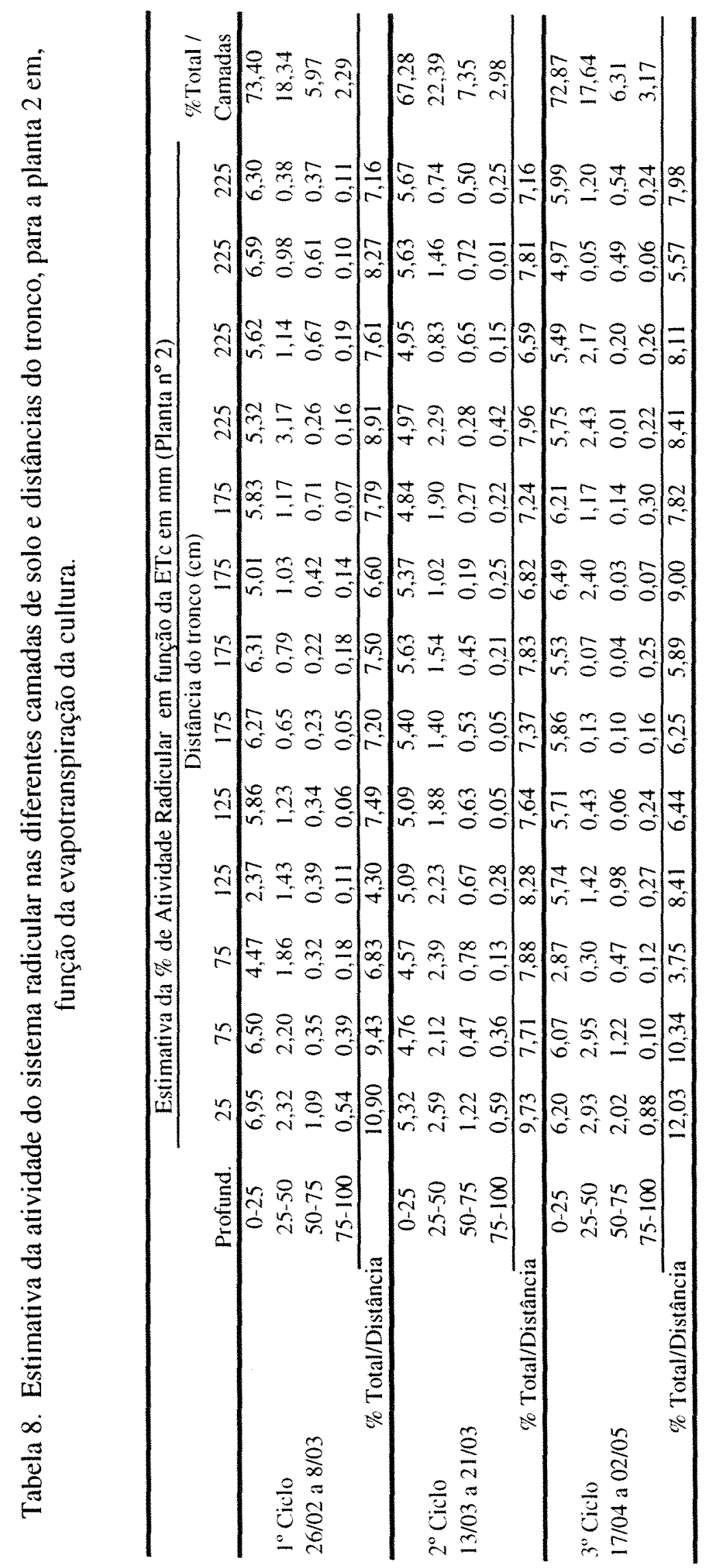




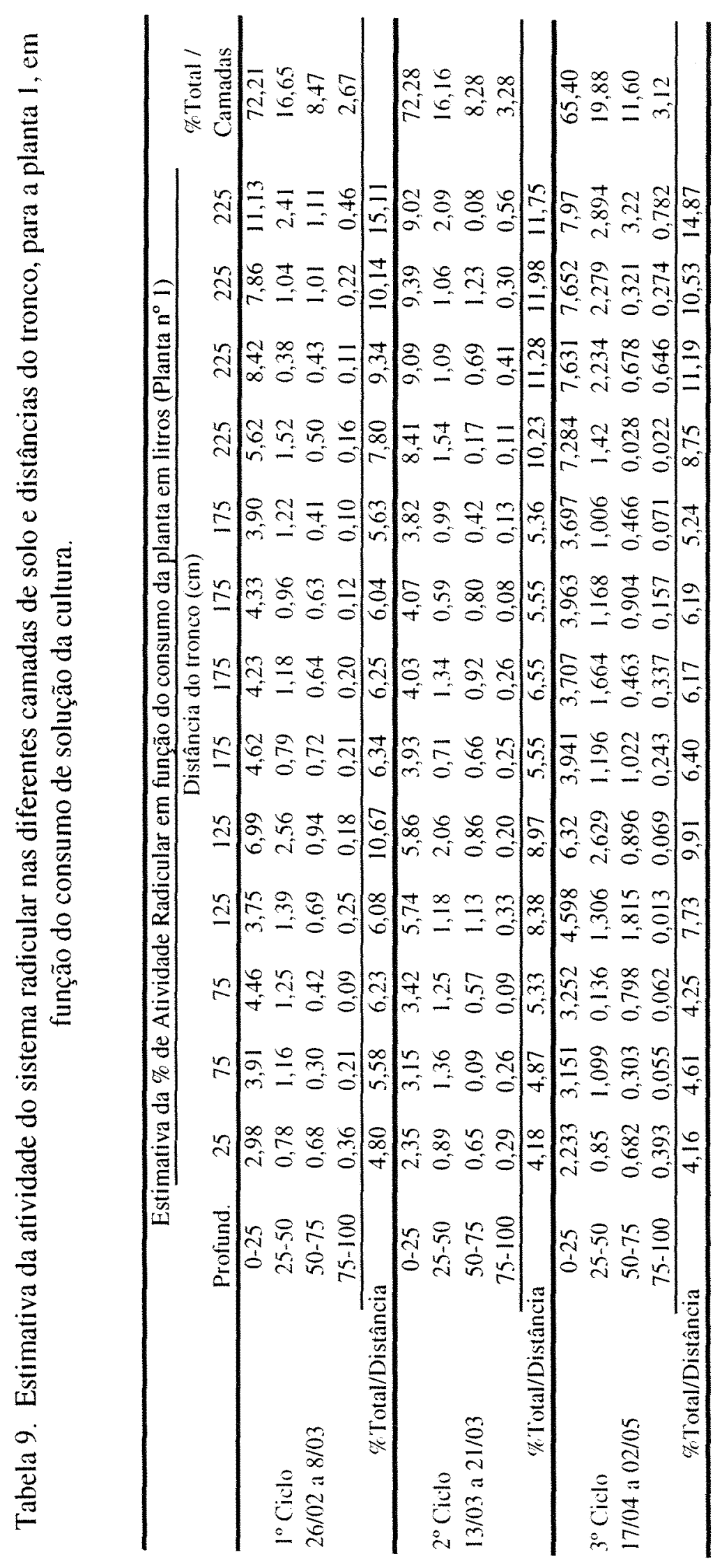




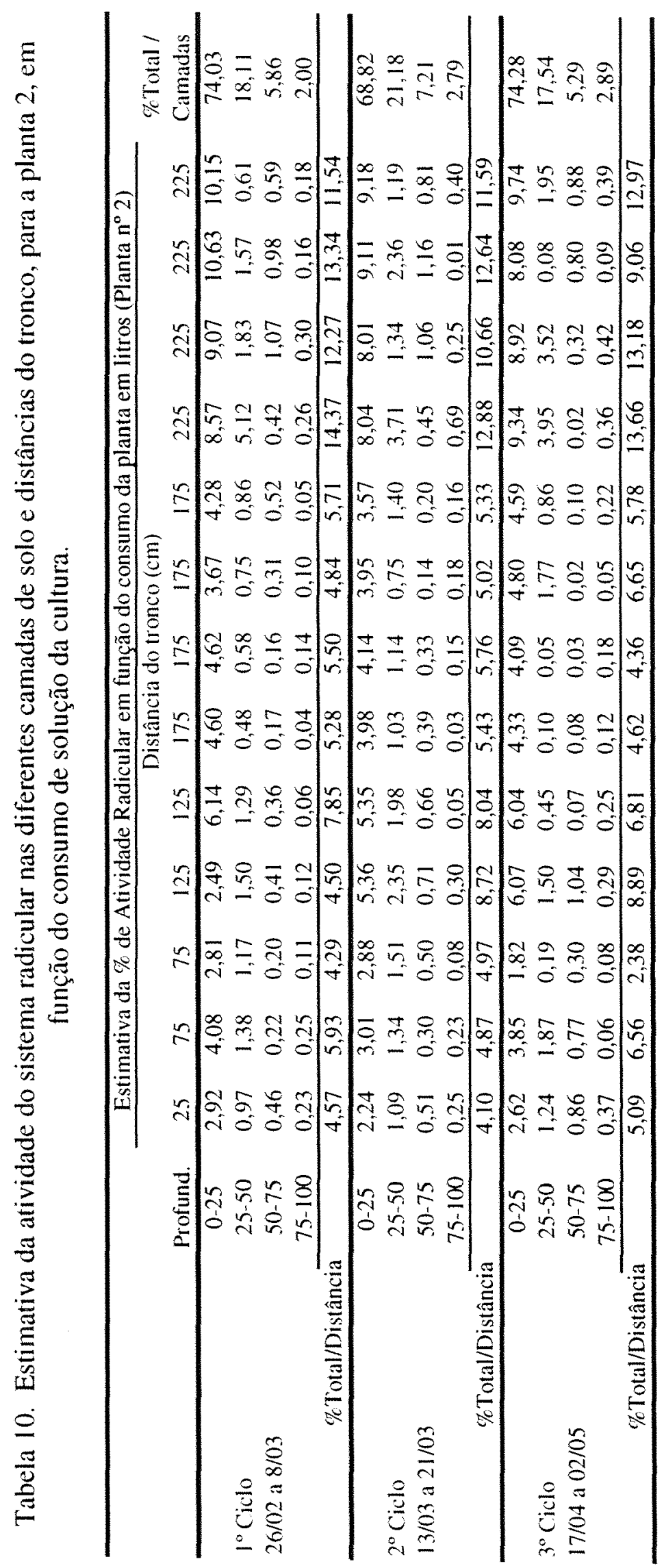

